\title{
REFLEXÕES SOBRE A EXPERIÊNCIA BRASILEIRA DE FINANCIAMENTO DA AGRICULTURA
}

\section{Humberto Francisco Silva Spolador}

Dissertação apresentada à Escola Superior de Agricultura "Luiz de Queiroz", Universidade de São Paulo, para obtenção do título de Mestre em Ciências, Área de Concentração: Economia Aplicada.

PIRACICABA

Estado de São Paulo - Brasil

Dezembro - 2001 


\title{
REFLEXÕES SOBRE A EXPERIÊNCIA BRASILEIRA DE FINANCIMENTO DA AGRICULTURA
}

\author{
Humberto Francisco Silva Spolador \\ Bacharel em Ciências Econômicas
}

Orientador: Prof. Dr. FERNANDO BENTO HOMEM DE MELO

Dissertação apresentada à Escola Superior de Agricultura "Luiz de Queiroz", Universidade de São Paulo, para obtenção do título de Mestre em Ciências, Área de Concentração: Economia Aplicada.

\author{
PIRACICABA \\ Estado de São Paulo - Brasil \\ Dezembro - 2001
}


Dados Internacionais de Catalogação na Publicação (CIP) DIVISÃO DE BIBLIOTECA E DOCUMENTAÇÃO - ESALQ/USP

Spolador, Humberto Francisco Silva

Reflexões sobre a experiência brasileira de financiamento da agricultura / Humberto Francisco Silva Spolador. - Piracicaba, 2001.

p.

Dissertação (mestrado) - - Escola Superior de Agricultura Luiz de Queiroz, 2002. Bibliografia.

1. Agricultura (Brasil) 2. Crédito rural 3. Custo economia 4. Formação de capital 5. Política agrícola I. Título

$\operatorname{CDD} 338.13$

"Permitida a cópia total ou parcial deste documento, desde que citada a fonte - $O$ autor" 


\section{Dedico}

Aos meus pais

João Francisco Spolador e Maria Aparecida Campos Silva Spolador

À minha irmã

Yara Maria Silva Spolador 


\section{AGRADECIMENTOS}

Ao professor Fernando Homem de Melo por sua inestimável orientação. Além de meu professor, desde os tempos de graduação, e meu orientador, o professor Fernando é um grande amigo, a quem deixo aqui registrada minha gratidão e admiração profissional.

Aos professores do Departamento de Economia e Sociologia da ESALQ/USP Paulo Cidade de Araújo, Ricardo Shirota, Alexandre Mendonça de Barros e Adriano Azevedo Filho que sempre me incentivaram a realizar este trabalho e em muito contribuíram para o enriquecimento do mesmo.

Ao professor Ruben Dario Almonacid por suas críticas, sugestões e, principalmente, pelo privilégio de trabalhar ao seu lado em diversas oportunidades.

Aos meus colegas de república Mauro, Ary, André e Frederico, e à dona Sônia pela amizade e convivência durante o período de mestrado.

Aos colegas de faculdade Rodrigo, Carlos, Cléa, Roberta, Vitor, Clarissa, Bel, Daniel, Henrique, Maurício, Alexandre, Fábio, Ricardo, Roberto, Marian (Morceguinha) e Aline (Tang) entre outros.

À Maria Emilia Furlan (Mila) por sua atenção e agilidade que muito facilitaram minha comunicação, mesmo que à distância, com meu orientador.

A todos os funcionários do DES e da biblioteca, especialmente à Maielli e à Ligiana por toda cooperação.

À CAPES pelo apoio financeiro. 


\section{SUMÁRIO}

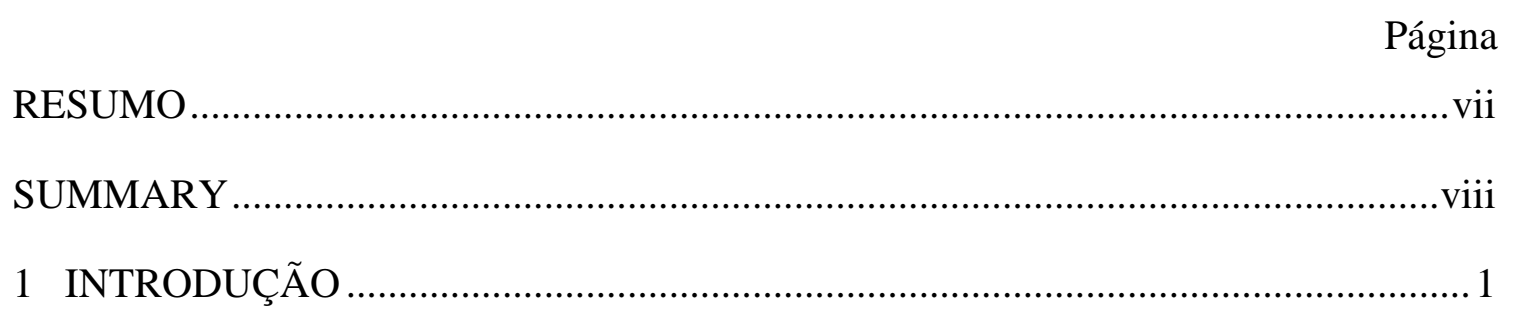

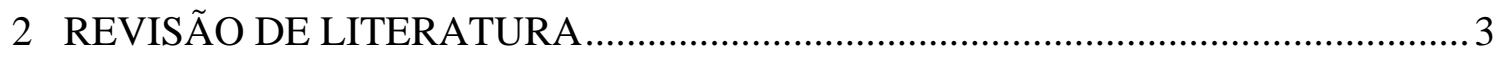

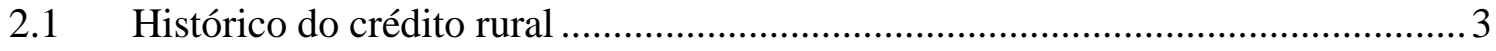

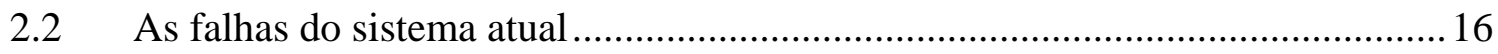

2.3 Novas propostas em questão ............................................................ 19

2.3.1 A mudança do paradigma no financiamento rural .......................................20

2.3.2 Propostas ainda discutidas no Congresso Nacional ..................................... 21

2.3.3 A Proposta da Tendência Consultoria Integrada............................................24

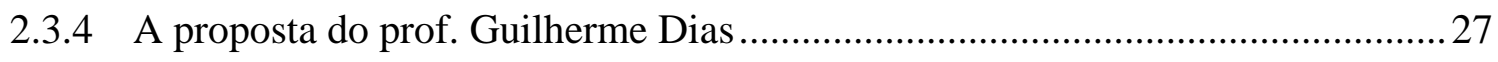

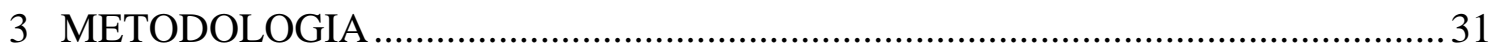

4 ANÁLISE TEÓRICA DO MERCADO DE CRÉDITO.......................................... 32

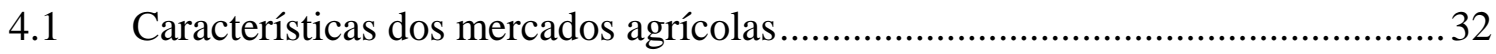

4.2 A importância do mercado financeiro........................................................... 33

4.2.1 O papel dos custos transacionais na oferta de crédito..................................... 34

4.2.2 Os custos bancários de transação do sistema de crédito rural no brasil: estimativas para os anos 90 .....

4.3 Assimetria de informação, risco moral, seleção adversa e intermediação financeira.... 
4.3.1 O racionamento como equilíbrio no mercado de crédito ................................... 46

4.3.2 O modelo de Stiglitz \& Weiss (1981) .......................................................... 47

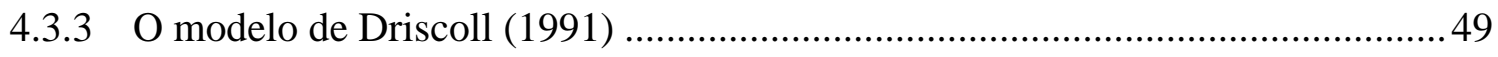

4.3.5 O modelo de Hoff \& Stiglitz (1993) ..........................................................53

5 ENTRAVES E NOVOS INSTRUMENTOS PARA UM NOVO MODELO DE

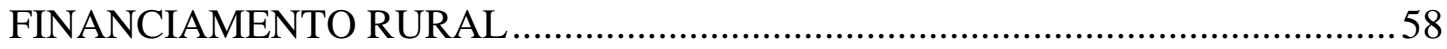

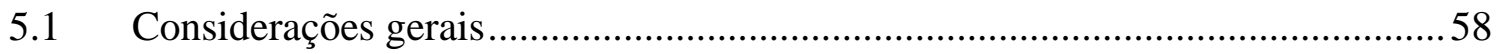

5.2 A CPR como um instrumento alternativo de captação de recursos ....................59

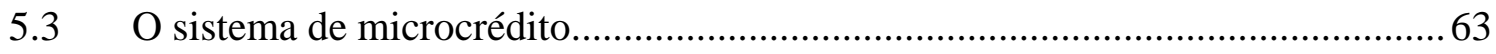

5.4 A opção de financiamento via mercados informais ....................................... 65

6 REFLEXÕES SOBRE UM NOVO MODELO DE FINANCIAMENTO RURAL...68

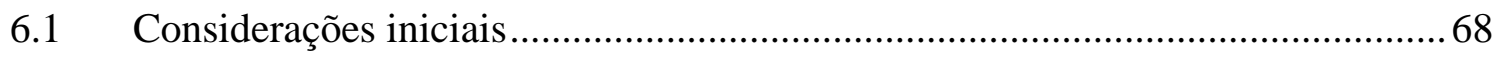

6.2 As taxas de juros como principal entrave macroeconômico .............................69

6.2.1 O plano real, a âncora monetária e a agricultura brasileira............................. 72

6.3 O papel do governo em um novo sistema de crédito .................................... 73

6.3.1 As equalizações como um instrumento de transição ...................................... 75

6.3.2 O papel das cooperativas na geração e difusão do crédito ................................ 76

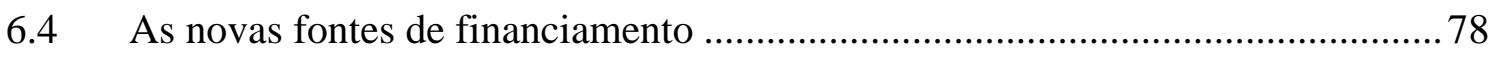

6.4.1 Sugestões do banco interamericano de desenvolvimento (BID) para estratégias de

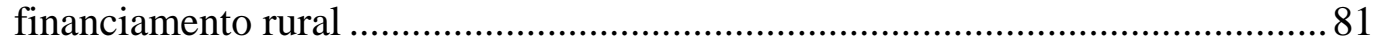

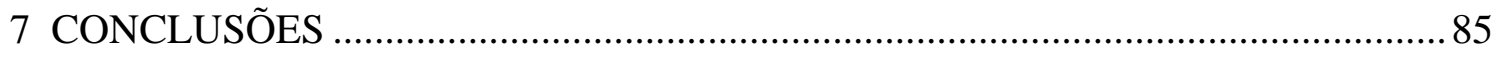

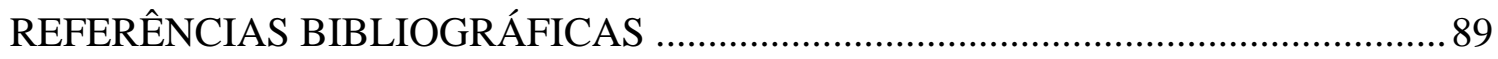




\title{
REFLEXÕES SOBRE A EXPERIÊNCIA BRASILEIRA DE FINANCIAMENTO DA AGRICULTURA
}

\author{
Autor: Humberto Francisco Silva Spolador \\ Orientador: Prof. Dr. Fernando Bento Homem de Melo
}

\section{RESUMO}

O presente trabalho tem por objetivo estudar a trajetória do crédito rural dos anos 60 até os dias de hoje, a fim de compreender a escassez de crédito do sistema atual, e as novas propostas em questão sob o enfoque dos modelos de competição imperfeita e assimetria de informação nos mercados de crédito. A natureza deste trabalho é essencialmente analítica, de forma que não foi estabelecido nenhum modelo empírico de teste e análise dos dados apresentados. Por outro lado, foi realizada uma revisão de literatura do crédito rural no Brasil e, também, uma revisão da literatura de teoria econômica sobre mercados de crédito ao longo dos últimos 20 anos. A falta de recursos do sistema tradicional de financiamento da agricultura é uma forte evidência do esgotamento do modelo tradicional. São vários os entraves para um novo sistema de financiamento, entre eles: uma legislação muito pouco adequada (que acaba por dificultar a concessão de empréstimos), o forte endividamento dos agricultores, os altos custos bancários de transação para concessão de empréstimos, a assimetria de informação no mercado e, no contexto macroeconômico, as altas taxas de juros praticadas na economia brasileira. A CPR (Cédula do Produto Rural), e o mecanismo de equalizações são importantes instrumentos em uma fase de transição de um sistema basicamente sustentado pelo Estado para um sistema cujos recursos sejam, em grande parte, gerados pelo mercado. 


\title{
REFLECTIONS ON THE BRAZILIAN EXPERIENCE OF AGRICULTURE FINANCING
}

\author{
Author: Humberto Francisco Silva Spolador \\ Advisor: Prof. Dr. Fernando Bento Homem de Melo
}

\section{SUMMARY}

The present work has for objective to study the path of the agricultural credit fo the $60^{\text {th }}$ until the present in order to understand the scarcity of credit in the current system, and the new proposals in question under the approach of the models of imperfect competition and asymmetry of information in the credit markets. The nature of this work is essentially analytical. In this context, it was not established and tested a empirical model or analysis of the data presented here. On the other hand, it was carried through a literature review about the agricultural credit in Brazil and the economic theory on markets of credit to the long one of last the 20 years. The lack of features in the traditional system of agriculture financing is one strong evidence of the debility of the traditional model. There are several impediments for a new system of financing, as: a smaller adjusted legislation (that results in difficulting the concession of loans), the strong indebtedness of the agriculturists, the high banking transaction costs for concession of loans, the asymmetry of information in the market and, in the macroeconomic context, the high taxes of interests practised in the Brazilian economy. The CPR (Cédula do Produto Rural), and the mechanisms of equalization are important instruments in the transition of a system supported basically by the State to a system whose features are, to a large extent, generated for the market. 


\section{INTRODUÇÃO}

A história do crédito rural formal no Brasil teve início em 1931, quando o governo federal, através do Banco do Brasil, e da criação do Departamento do Café, passou a financiar compras de café (Guedes, 1999). As pressões, para que outros setores da agricultura, obtivessem o mesmo apoio creditício aumentaram com a crise financeira dos anos 30. Dessa forma, a CREAI (Carteira de Crédito Agrícola e Industrial do Banco do Brasil) se tornou o primeiro grande mecanismo de crédito agrícola no Brasil. A partir de 1965, através da lei 4.289, a política de crédito agrícola se consolidou no Brasil com a criação do Sistema Nacional de Crédito Rural (SNCR). Os principais objetivos do SNCR eram:

1) financiamento de parte dos custos de produção agrícola,

2) estimular a formação de capital,

3) acelerar a adoção de novas tecnologias e

4) fortalecer a posição econômica dos produtores, especialmente os pequenos e médios.

Conforme Araújo \& Meyer (1977), com a implementação do Sistema Nacional de Crédito, observou-se, entre 1965 e 1975, aumento da produção e modernização do setor, além da concentração do crédito entre poucos e grandes produtores. No entanto, a partir de meados dos anos 70, em função da mudança de rumos da economia mundial, a economia brasileira passou a sofrer pressão inflacionária e desequilíbrios no balanço de pagamentos (Mendonça de Barros, 1979). A política agrícola, então, teve que se ajustar à nova situação e em função do fato do governo se tornar incapaz de destinar um vigoroso montante de recursos ao crédito rural, o sistema criado em 1965 começou a se tornar inviável. 
O processo inflacionário gerou maior subsídio creditício (pois a taxa de juros nominal era inferior à taxa de inflação), e o crédito não sofria correção monetária total, o que proporcionou o aumento das desigualdades distributivas (apenas 20\% dos produtores obtinham crédito formal). Além do mais, o crescente déficit fiscal do governo terminou por inviabilizar sua participação no financiamento da atividade agrícola (Mendonça de Barros, 1979).

Gasques et al. (2000) mostram que a média de aplicações, nos últimos anos da década de 90 , representava menos de $30 \%$ do que se aplicava no auge do sistema de crédito rural, durante os anos 70. Este resultado se deve à constatação de que os mecanismos tradicionais de financiamento, fortemente apoiados nos recursos do Tesouro, estavam esgotados, além da necessidade de se controlar os gastos do setor público e da incapacidade do governo em desenhar um modelo alternativo.

Nas fontes de recursos se concentraram as principais mudanças no crédito rural. Em 1985, os desembolsos do Tesouro, juntamente com os Recursos Obrigatórios, representavam 96\% do crédito rural, ao passo que no final de 1999 esse valor não ultrapassava 0,02\%. Por outro lado, o FAT (Fundo de Amparo ao Trabalhador Rural) juntamente com a Poupança Rural, e os Recursos Obrigatórios, se tornaram responsáveis, em fins de 1999, por 79\% do financiamento. A atuação do governo, nessa nova realidade, passou a ser de agente regulador e estimulador (Gasques et al., 2000).

Não são poucos, nos dias de hoje, os entraves para a formulação de uma nova e eficiente política de crédito. Além da saída do governo como principal fomentador de recursos, e das elevadas dívidas de produtores de médio e grande porte, as altas taxas de juros praticadas no mercado financeiro brasileiro limitam, em muito, a implementação de outros mecanismos de financiamento menos dependentes da intervenção oficial.

O presente trabalho tem por objetivo, depois de uma revisão de literatura e apresentação da abordagem teórica do mercado de crédito, apresentar os novos instrumentos de financiamento rural que surgiram na agricultura brasileira nos últimos anos e, na última seção, apresentar sugestões, fundamentadas na teoria discutida ao longo do trabalho, que possam colaborar para a implementação de um modelo mais eficiente e sustentável de crédito rural para o Brasil. 


\section{REVISÃO DE LITERATURA}

\subsection{Histórico do crédito rural}

Conforme já foi mencionado, as primeiras experiências de crédito rural formal no Brasil datam dos anos 30. No entanto, no período entre 1940 a 1960, inexistiu uma política agrícola interna ao setor, ou seja, com o objetivo de prover o aumento da renda, do emprego etc. Pouca importância foi dada aos investimentos de longo prazo (especialmente o fator humano), e aos investimentos em infra-estrutura como transportes, comunicações, armazenagem e portos. Destaca-se, ainda, que as principais políticas conduziam à transferência de recursos dos setores agrícolas para os setores não agrícolas, o que corresponde à lógica do desenvolvimento econômico brasileiro de correr em direção à urbanização e industrialização (Mendonça de Barros, 1979).

Devido a tão poucos programas de investimentos destinados à agricultura, verificou-se um período de crises de produtos alimentares e inquietação urbana. Os poucos investimentos em infra-estrutura ${ }^{1}$ não foram suficientes para impedir algumas crises de crescimento do setor, e nos anos cinqüenta ocorreram aumentos sucessivos dos preços dos produtos agrícolas, culminando com uma crise de provisão de alimentos em fins de 1959 (Meyer et al., 1973). Nesse momento inicia-se uma expansão no crédito agrícola. Entre 1962 e 1963, dado uma nova crise de provisão de alimentos, começa a haver um interesse maior em se estabelecer uma política agrícola, e creditícia, mais consistente.

No início dos anos sessenta um conjunto de medidas, fiscais e monetárias, do Ministério da Fazenda e do Banco Central tiveram por objetivo estimular a produção agrícola do Brasil, fazendo o crédito rural parte deste contexto.

\footnotetext{
${ }^{1}$ Foram realizados alguns investimentos em infra-estrutura de comercialização, pois nos anos 50 ocorreram inúmeras perdas nos canais de comercialização de alimentos (Meyer et al., 1973).
} 
A política de crédito agrícola foi estabelecida pela Lei 4829, de 1965, cujos objetivos eram estimular os investimentos na agricultura, fortalecer a situação financeira dos produtores e adoção de tecnologia moderna no setor rural (Meyer et al., 1973). A legislação estabelecia que dez por cento dos depósitos bancários comerciais deveriam ser designados a empréstimos agrícolas, sendo que em 1973 (através de Resolução 260) esse valor passou a ser de quinze por cento dos depósitos em bancos comerciais. Ainda era garantido pela legislação que as taxas de juros para os empréstimos rurais não poderiam ser superiores a setenta e cinco por cento das taxas cobradas em empréstimos comerciais.

O resultado da nova política de crédito rural foi o aumento no volume de crédito concedido, bem como o aumento das instituições fornecedoras de empréstimo. $\mathrm{O}$ Banco do Brasil passou a ser responsável por noventa por cento dos empréstimos, o que representou uma tendência de diminuição da concentração de crédito entre pequenos grupos (em especial do café), e elevando a maior distribuição entre os tomadores de empréstimos (em tese, a presença do Banco do Brasil no financiamento tornaria mais acessíveis os recursos aos produtores). Os dados (expostos na tabela 1) de 1969 mostravam que a participação no crédito de certas regiões era proporcional ao produto local como proporção do produto agrícola total (Tendler, 1969). 
Tabela 1. Porcentagem de cada região no crédito rural e no produto agrícola, 1968.

\begin{tabular}{ccccc}
\hline Região * & Bancos Privados & Bancos Públicos & CREAI & \% do Produto Agrícola \\
\hline Norte & 0.6 & 8.7 & 1.3 & 1.9 \\
Nordeste & 3.6 & 45.8 & 11.3 & 16.4 \\
Leste & 37.1 & 21.1 & 19.8 & 25.8 \\
Sul & 54.5 & 21.5 & 55.2 & 50.2 \\
Centro-Oeste & 1.1 & 2.4 & 12.4 & 5.8 \\
\% da Amostra & 96.9 & 99.5 & 100 & 100 \\
$\%$ Total & 100 & 100 & 100 & 100 \\
\hline
\end{tabular}

Fonte: Tendler (1969)

* Norte: Amazonas, Pará, Acre, Território do Amapá, Território do Roraima. Nordeste: Maranhão, Piauí, Ceará, Rio Grande do Norte, Paraíba, Pernambuco, Alagoas. Leste: Sergipe, Bahia, Espírito Santo, Rio de Janeiro, Guanabara, Minas Gerais. Sul: São Paulo, Paraná, Santa Catarina, Rio Grande do Sul. Centro-Oeste: Mato Grosso, Território de Rondônia, Distrito Federal.

Até 1964 a participação da agricultura no crédito total destinado a investimentos da economia era menor que sua participação no PIB (algo em torno de 29\%). As medidas adotadas em 1965 tiveram rápido efeito, pois em 1966 a participação da agricultura no crédito total era de 53,3\% chegando a 71\% em fins de 1968 (Tendler, 1969).

No período 1970/75 os índices área/crédito e área por produção declinam sensivelmente, mesmo considerando os preços maiores dos fertilizantes e de outros insumos. As elevações das taxas de inflação, e liberação das taxas de juros, fizeram (possivelmente) com que os bancos do SNCR passassem a contar com um volume maior de clientes, e dessem preferência àqueles de tamanho e liquidez maior, diminuindo, portanto, a eficácia do sistema (Sayad, 1978).

No início dos anos 70 a crise internacional do petróleo modificou a situação econômica mundial; no Brasil a economia passou a apresentar tendência inflacionária e crise no balanço de pagamentos. A política agrícola, em relação aos anos sessenta, não se alterou no que diz respeito a instrumentos e linhas de ação, houve apenas uma 
mudança de prioridades (Barros, 1979). A política de crédito promove o aumento do volume de recursos e do subsídio (modesto até 1973), além do aumento na participação de aplicações das autoridades monetárias.

O objetivo da política de crédito, dadas as crises interna e externa, era contornar os desequilíbrios da economia visto que o subsídio implícito poderia manter a rentabilidade das exportações, e evitar a elevação dos preços internos. Conforme atestam Barros (1979) e Sayad (1978) a política de crédito agrícola, na forma em que foi conduzida na década de 70 , esgotou todas as suas potencialidades e passou a ser criticada em três níveis: eqüidade, eficiência e impactos sobre a política monetária.

No que se refere à eqüidade e eficiência, Sayad (1978) explora exaustivamente as falhas da política de crédito rural. Em relação à eqüidade, o autor argumenta que o subsídio implícito (ao passo que a taxa de inflação aumentava a taxa de juros nominal não acompanhava, o que tornava negativa a taxa de juros real, configurando um subsídio implícito) eleva-se vigorosamente após 1974, à medida que o processo inflacionário volta a acelerar- $\mathrm{se}^{2}$, a proporção dos produtores que obtêm crédito formal não ultrapassa a vinte por cento do total e, ainda, entre os que obtêm crédito, a maioria é de grandes proprietários de terra (como mostra a tabela 2).

Tabela 2. Distribuição do crédito declarado na amostra segundo classificação das fazendas pelo critério do INCRA, 1978.

\begin{tabular}{cccc}
\hline & Crédito Total & Crédito de Curto Prazo & $\begin{array}{c}\text { Crédito de Longo } \\
\text { Prazo }\end{array}$ \\
\hline Minifúndios & 19.5 & 15.9 & 21.2 \\
Empresas Rurais & 29.9 & 45.2 & 19.9 \\
Latifúndios por & 52.8 & 39.1 & 59.1 \\
Exploração & 100 & 100 & 100 \\
Total & & & \\
\hline
\end{tabular}

Fonte: Sayad (1978)

\footnotetext{
${ }^{2}$ A legislação do crédito rural impedia que a taxa de juros nominal fosse superior a $75 \%$ da taxa de juros do crédito comercial. Com a elevação da taxa de inflação, a taxa de juros real tornou-se negativa, implicando em um subsídio ao produtor rural.
} 
Sayad (1978) define eficácia de um sistema de crédito como "um acréscimo de investimentos na agricultura obtido a partir de um acréscimo nos saldos de crédito rural". Um mercado financeiro bem desenvolvido amplia as possibilidades de substituição, ou seja, com um crédito, por exemplo, de dez por cento do governo o produtor diminui seus recursos próprios em dez por cento e os investe em ativos mais rentáveis $^{3}$; logo um aumento do crédito não é acompanhado pelo aumento da produção. Sayad (1978) conclui que se o volume de crédito fosse gasto em uma política de subsídio direto à produção, o mesmo montante de dispêndio geraria um aumento de produção sensivelmente maior; para cada $1 \%$ de aumento de preço, haveria aumento (na produção) superior a 7\% do valor obtido nos programas de crédito rural.

O Programa Nacional de Crédito Rural foi duramente criticado no começo dos anos 80. Os principais argumentos eram de que seus efeitos eram poucos significativos sobre o crescimento da produção agrícola, e sobre as tecnologias adotadas pelos produtores e sobre a elevação da produtividade (Sayad, 1982). Nesse período os desequilíbrios da economia brasileira haviam se acentuado no front externo (a crise da dívida) e, internamente, com a aceleração do processo inflacionário. Como as taxas de juros dos empréstimos agrícolas eram inferiores às cobradas no mercado financeiro, em anos de inflação alta os custos do programa se tornaram muito maiores que os benefícios. Outro efeito perverso do sistema ocorria em relação ao processo distributivo do financiamento, pois as taxas de juros eram mantidas constantes mesmo em períodos de elevação dos preços, de modo que a maior parte dos subsídios acabava sendo distribuída aos grandes proprietários de terra (Mata, 1982).

Para conter o processo inflacionário o governo, nos primeiros anos da década de 80 , determinou como objetivo da política monetária a redução da oferta dos meios de pagamento. O corte no crédito rural seria tão mais eficiente na contenção do crescimento da oferta monetária quanto maior fosse sua participação no total das aplicações das autoridades monetárias. Sayad (1982) mostra que o crédito rural chegou a representar, em 1980, 20\% da soma da base monetária e dívida pública; em 1981 esse valor se

\footnotetext{
${ }^{3}$ É o chamado efeito substituição que depende das características dos tomadores: grandes tomadores, ou tomadores próximos de centros financeiros, por exemplo.
} 
reduziu para $12 \%$, o que mostrava que a redução no ritmo de crescimento da oferta dos meios de pagamento não poderia prescindir dos cortes nas disponibilidades de crédito rural.

Oliveira \& Montezano (1982) defenderam a idéia de que os mecanismos de geração de recursos para a agricultura eram eficazes à época de sua criação, meados dos anos 60 , porém ao longo do tempo foi perdendo eficiência face às transformações da estrutura financeira do país. Os recursos monetários não inflacionários, depósitos à vista em bancos comerciais, que representavam parcela importante dos empréstimos totais foram sistematicamente perdendo importância, chegando a representar uma pequena parcela dos fundos financeiros totais da economia no começo dos anos 80, especialmente com o agravamento do processo inflacionário.

Ao passo que as fontes de financiamento se exauriam, a demanda por crédito agrícola se expandia rapidamente (em decorrência de condições propícias do mercado externo e interno para os produtos agrícolas), o que provocava dois efeitos: inócuo aumento do percentual de depósitos à vista destinados aos empréstimos, e pressões crescentes sobre a atuação monetária do governo. Conforme foram se esgotando as fontes de recursos não inflacionárias (o aumento da inflação fazia com que o público evitasse os depósitos à vista, optando por aplicações financeiras indexadas), o sistema de crédito foi se tornando cada vez mais dependente da aplicação compulsória dos bancos, e da complementação feita pelas Autoridades Monetárias, fato esse que Oliveira \& Montezano (1982) denominaram de "estatização do crédito rural no Brasil”.

Segundo Oliveira (1995) o entendimento de que uma das causas do processo inflacionário seriam os subsídios concedidos ao crédito rural e as emissões monetárias para financiar o programa de financiamento da atividade agrícola, e que esses fatores diminuíam a eficiência da política monetária pela existência da conta movimento do Banco do Brasil, levou o governo a alterar a política de crédito rural. Em 1984 o fim da conta movimento se constituiu em um dos objetivos da unificação orçamentária, que ocorreria em 1986.

O diagnóstico geral da economia brasileira na década de 80 era de que a crise fiscal tornou o Estado incapaz de fomentar recursos à agricultura (que acabavam sendo 
subsidiados em função de taxas de juros reais negativas). Os dados de Oliveira (1995) refletem a impossibilidade de se manter a "estatização do crédito rural"; em 1981 a dívida pública federal representava 19,5\% dos haveres financeiros totais, valor esse que atingiu 54,2\% em 1987. Tal quadro ilustra a necessidade de uma reestruturação dos gastos do governo, o que acabou por inviabilizar a atuação do mesmo no sistema de crédito rural nos moldes anteriores.

Apesar do cenário extremamente desfavorável (ilustrado na figura 1), o crédito rural teve um crescimento da ordem de 39,46\% em 1985, e de 54,61\% em 1986 (Oliveira, 1995). Tal fato deve ser atribuído à monetização da economia provocada pelo Plano Cruzado. Abreu (1990) registra que a base monetária aumentou 293\% de 1985 para 1986, e os depósitos à vista (em função da queda da inflação) tiveram um aumento de $306 \%$ no mesmo período.

Entre as mudanças orçamentárias e institucionais, Servilha (1994) menciona que os fatores que provocaram uma alteração no padrão das fontes de recursos foram: i) redução da participação das autoridades monetárias; ii) uso mais intensivo de recursos próprios dos produtores; iii) custos dos empréstimos próximos dos vigentes no mercado financeiro. Das mudanças orçamentárias e institucionais deve-se ressaltar: reforma nas contas públicas, unificação orçamentária, fim da conta movimento do Banco do Brasil e criação da Secretaria do Tesouro Nacional, que passou a controlar as operações realizadas por ordem do Tesouro Nacional (Oliveira, 1995). 


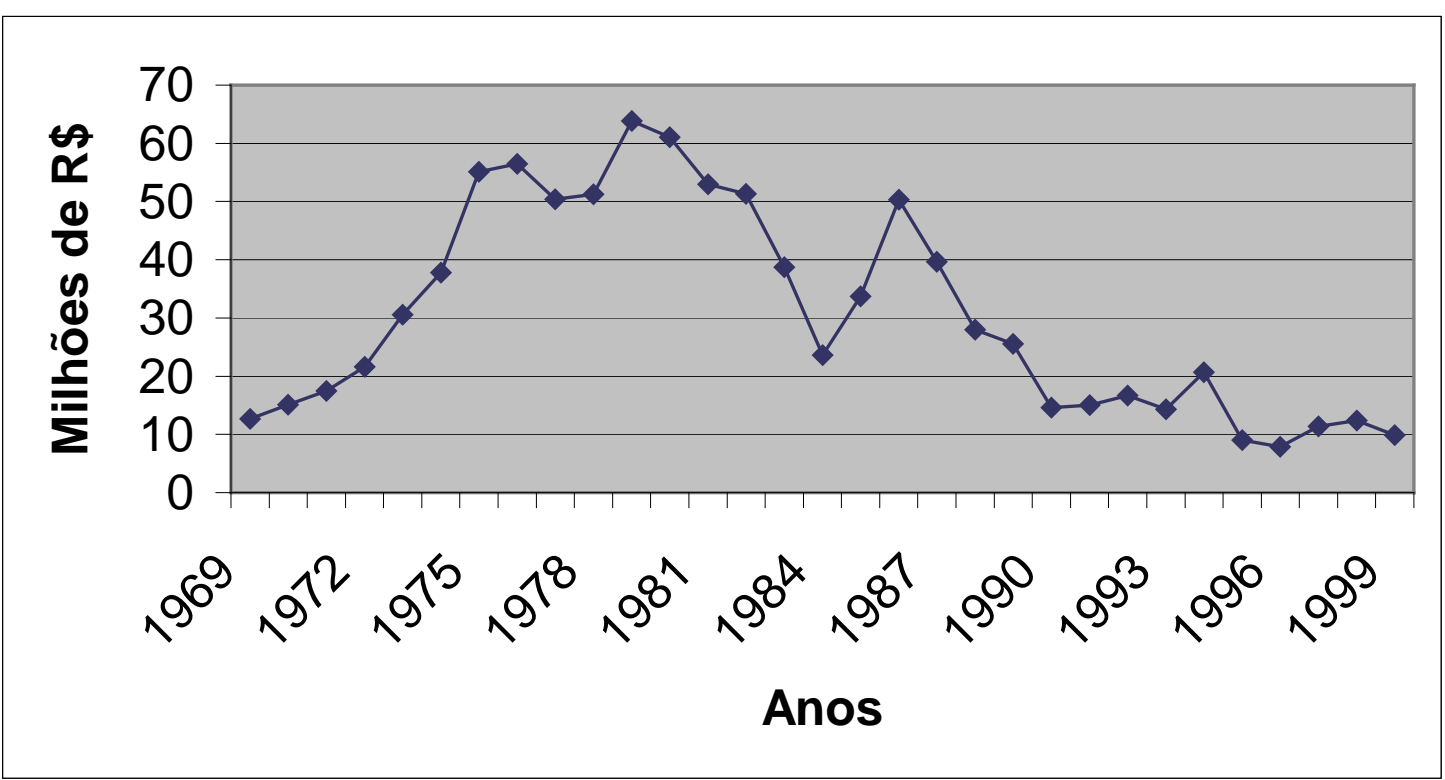

Figura 1 - Financiamentos concedidos por categoria pelo Sistema Nacional de Crédito Rural (milhões de reais em 1999).

Fonte: Dados obtidos a partir de Gasques et al. (2000)

Nos últimos trinta e cinco anos, apesar da drástica redução do volume de recursos do governo destinados ao financiamento da atividade rural, observa-se pela figura 2 que a produção de grãos (mais dependente do crédito) no Brasil teve um desempenho altamente satisfatório. Esse resultado deve-se, em grande parte, ao aumento da produtividade advinda de novas, e mais eficientes técnicas de produção, melhor capacitação técnica, criação da Embrapa entre outros (Melo, 1997). 


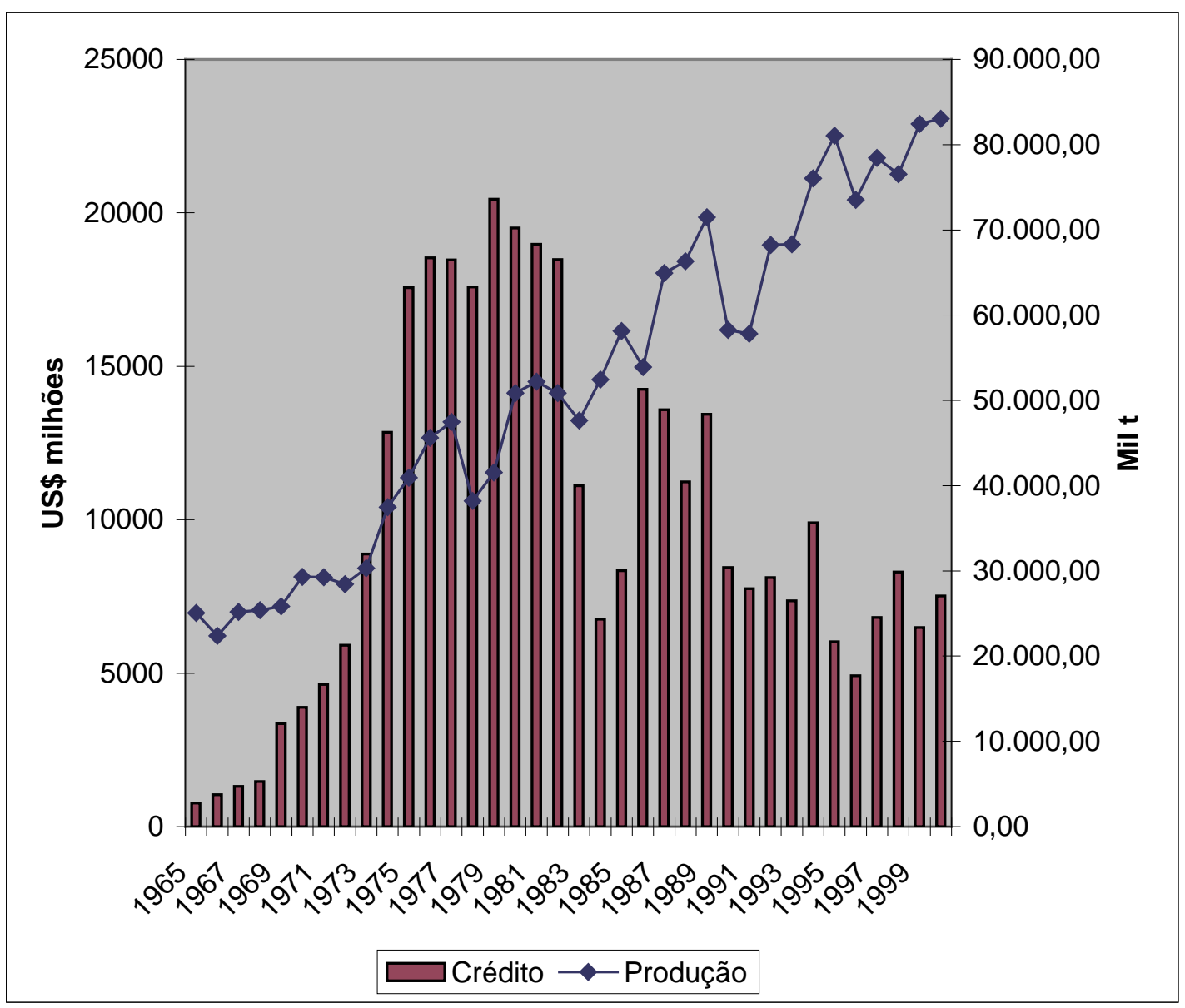

Figura 2 - Relação entre Crédito Rural e Produção de Grãos (1965 - 2000).

Fonte: Crédito IBGE (1965 a 1968) Instituto Brasileiro de Geografia e Estatística BACEN (1969 a 2000) - Banco Central do Brasil Produção: IBGE

Crédito do ano 1 dividido pela produção do ano 2

Com abertura do mercado flutuante em 1989 iniciou-se o processo de inserção da economia brasileira nos mercados internacionais, processo esse que continuaria ao longo da década de 90. Como mostra Melo (1997), a década passada pode ser dividida em dois períodos: 1) redução de tarifas e desvalorização da moeda no governo Collor; 2) abertura comercial e drástica valorização cambial até 1999. Schouchana \& Perobelli (2000) ressaltam, ainda, o processo de estabilização dos preços e a gradual saída do governo no financiamento da atividade produtiva como outras características marcantes da década passada. 
Além da valorização cambial, afirma Melo (1997), prejuízos aos preços agrícolas ocorreram em virtude das taxas de juros reais extremamente elevadas no mercado financeiro, das baixas tarifas de importação (durante a década), e das importações financiadas de produtos agrícolas.

Embora seja destacada a mudança no padrão de atuação do governo, e o aumento das fontes alternativas de financiamento, deve-se considerar que o governo, via Banco do Brasil, ainda tem sido o principal fomentador de recursos destinados ao crédito rural, como ilustrado na tabela 3.

Tabela 3. Recursos destinados ao crédito rural (R $\$$ milhões de 1999).

\begin{tabular}{ccc}
\hline Custeio agrícola e pecuário & 1998 & 1999 \\
\hline Banco do Brasil & $4.602,3$ & $4.718,8$ \\
Demais Bancos & $2.398,0$ & $2.232,2$ \\
\hline
\end{tabular}

Fonte: Schouchana \& Perobelli (2000)

Gasques et al. (2000) atribuem as novas formas de atuação do governo à política fiscal, o esforço de modernização do Estado e o controle dos gastos públicos. Face à necessidade de novas fontes alternativas de financiamento o governo, agora como agente regulador e estimulador, passou a apoiar a criação de novas fontes de recursos (a CPR - Cédula do Produto Rural, por exemplo), abandonando a forma de atuação do período anterior, ou seja, a função de principal gerador de recursos de crédito rural.

Em 1988, com o objetivo de incentivar novas fontes não-inflacionárias de financiamento, a Constituição daquele ano criou os Fundos Constitucionais de Financiamento (FNO, FNE e FNECO) que seriam gerados através da alíquota de 3\% da arrecadação do IPI e do IR.

O BNDES, em 1991, a fim de aumentar a oferta de crédito rural formal, aumentou de forma significativa sua carteira de aplicações agropecuárias através da FINAME-Rural, do POC (Programa de Operações Conjuntas) e de programa de operações diretas do próprio banco. Os recursos advindos do FINAME são destinados ao 
financiamento de máquinas e equipamentos, sendo aplicados através de agentes financeiros como Banco do Brasil, Bradesco, Banco do Nordeste, Banresul, e BRDE (Araújo et al., 1999).

A CPR - Cédula do Produto Rural, foi criada em 1994 inspirada, conforme Araújo et al. (2001), nas cédulas de crédito rural e industrial criadas em 1967 e 1969 respectivamente. A vantagem da CPR é permitir a venda antecipada, à vista, de parte da produção. Araújo $(1999)^{4}$ define como as principais características da CPR: i) título líquido e certo, transferível por endosso e exigível pela qualidade e quantidade de produto nele previsto; ii) preço livremente ajustado entre as partes; iii) admite garantias ajustadas entre as partes, como hipoteca, penhor, alienação fiduciária e aval; iv) possibilita a inclusão de cláusulas estabelecidas pelas partes, no ato da emissão, além de ativos posteriores; v) está sujeita às normas do direito cambial; vi) enquanto vincenda, é um ativo financeiro, sem a incidência do ICMS, podendo ser negociada em bolsas de mercadorias e de futuros ou em mercado organizado em leilão eletrônico e autorizado pelo Banco Central; vii) negócios com CPR, em boa parte, são registrados na CETIP (Central de Custódia e Liquidação Financeira de Títulos) para se evitar a duplicidade de venda. Atualmente, negócios com pouca representatividade foram feitos com álcool, milho, algodão, suco de laranja, arroz e boi. O maior volume de negócios com CPR foram realizados com soja e café.

A partir de 1994 houve um endividamento crescente por parte dos produtores rurais. Araújo et al. (1999) afirmam que o vigoroso aumento da dívida dos agricultores deveu-se, em grande parte, ao freqüente descasamento entre a correção de preços mínimos e correção da dívida. Santiago (2000) cita que, a partir do Plano Collor I, a defasagem entre a correção dos preços mínimos pelo IPC foi de 41,28\%, enquanto que a dívida dos agricultores foi corrigida, pelo mesmo indicador, em torno de 84,23\%.

${ }^{4}$ ARAÚJO, P.F. C. Crédito rural em período recente e perspectivas para 1999 - 2000. Comunicação pessoal, São Paulo: M.B. Associados, 1999. 16p. (Não publicado) 
O Programa de Securitização ${ }^{5}$ foi implementado em 1996 para os agricultores com dívida até R $\$ 200$ mil, com prazo de sete anos e com juros de 3\% ao ano mais a variação do preço mínimo de um produto amparado pela política de preços mínimos (Araújo et al., 1999). Também neste ano teve início o PRONAF - Programa de Fortalecimento da Agricultura Familiar, destinado aos agricultores que se utilizam basicamente de mão-de-obra familiar, sendo limitado a R \$ 5 mil para custeio, R\$ 15 mil para comercialização e $\mathrm{R} \$ 75$ mil por mutuário para investimentos. Isso representou uma importante reorientação na distribuição dos recursos de crédito.

Os grandes agricultores, cujas dívidas excediam os limites do programa de securitização, foram socorridos através do Programa Especial de Saneamento de Ativos (PESA). Nesse programa o agricultor adquire títulos junto ao Tesouro Nacional (resgatáveis após vinte anos) no valor correspondente a 10,37\% do valor da dívida junto aos bancos comerciais. Para os contratos acima de R 500 mil os juros nominais são de $8 \%$ ao ano sobre o principal, sendo o valor atualizado anualmente pelo IGP - M (Araújo, 1999).

Ainda em 1996, o governo federal passou a destinar recursos do FAT - Fundo de Amparo ao Trabalhador para os empréstimos rurais, especialmente o PRONAF, e do FAE - Fundo Extra Mercado ou reservas financeiras de algumas estatais.

\footnotetext{
${ }^{5} \mathrm{O}$ processo de securitização é a transformação de receitas futuras em títulos que, por sua vez, são vendidos ao mercado de capitais. No caso da agricultura, o Tesouro Nacional se compromete a emitir títulos para garantir os contratos firmados entre agricultores e bancos (Lima, 1999).
} 
Tabela 4. Financiamentos concedidos por fontes de recursos (valores em \%).

\begin{tabular}{|c|c|c|c|c|c|c|c|c|c|c|}
\hline $\begin{array}{l}\text { Fonte de } \\
\text { Recursos }\end{array}$ & 91 & 92 & 93 & 94 & 95 & 96 & 97 & 98 & 99 & 00 \\
\hline $\begin{array}{l}\text { Recursos do } \\
\text { Tesouro }\end{array}$ & 24,18 & 22,97 & 26,67 & 27,11 & 19,70 & 3,48 & 1,50 & 1,66 & 0,11 & 0,02 \\
\hline $\begin{array}{l}\text { Recursos } \\
\text { Obrigatórios }\end{array}$ & 22,38 & 18,71 & 11,04 & 11,60 & 13,14 & 16,88 & 44,89 & 40,73 & 41,68 & 55,95 \\
\hline Popança Rural & 32,29 & 45,53 & 43,22 & 34,90 & 36,07 & 9,13 & 8,42 & 13,02 & 19,47 & 12,18 \\
\hline Recursos Livres & 10,32 & 6,76 & 11,74 & 15,93 & 16,30 & 8,07 & 6,01 & 4,67 & 5,06 & 4,97 \\
\hline $\begin{array}{l}\text { Fundos } \\
\text { Constitucionais }\end{array}$ & 3,22 & 3,15 & 5,52 & 4,99 & 9,01 & 14,90 & 5,64 & 7,04 & 5,75 & 5,43 \\
\hline $\begin{array}{l}\text { Recursos dos } \\
\text { Governos } \\
\text { Estaduais }\end{array}$ & 0,12 & 0,07 & 0,10 & 0,26 & 0,36 & 0,26 & 0,18 & 0,18 & 0,13 & 0,10 \\
\hline $\begin{array}{l}\text { Fundo de } \\
\text { amparo ao } \\
\text { trabalhador }\end{array}$ & 0,00 & 0,00 & 0,00 & 0,00 & 0,00 & 21,99 & 18,43 & 15,86 & 15,92 & 11,29 \\
\hline $\begin{array}{l}\text { Fundo Extra- } \\
\text { Mercado }\end{array}$ & 0,00 & 0,00 & 0,00 & 0,00 & 0,00 & 13,93 & 6,66 & 1,11 & 0,00 & 0,00 \\
\hline $\begin{array}{l}\text { Recursos do } \\
\text { Funcafé }\end{array}$ & 0,00 & 0,00 & 0,00 & 0,00 & 0,00 & 0,00 & 3,60 & 5,54 & 5,00 & 1,66 \\
\hline $\begin{array}{l}\text { Fundo de } \\
\text { Commodities }\end{array}$ & 0,00 & 0,00 & 0,00 & 0,00 & 0,00 & 0,00 & 0,11 & 0,05 & 0,06 & 0,07 \\
\hline BNDES/FINA & 0,00 & 0,00 & 0,00 & 0,00 & 0,00 & 0,00 & 3,38 & 4,06 & 4,67 & 6,26 \\
\hline ME & & & & & & & & & & \\
\hline INCRA/PROC & 0,00 & 0,00 & 0,00 & 0,00 & 0,00 & 0,00 & 0,46 & 1,14 & 0,30 & 0,05 \\
\hline ERA & & & & & & & & & & \\
\hline Outras Fontes & 7,47 & 2,81 & 1,72 & 5,21 & 5,43 & 11,37 & 0,70 & 2,07 & 0,38 & 0,89 \\
\hline 63 Rural & 0,00 & 0,00 & 0,00 & 0,00 & 0,00 & 0,00 & 0,00 & 2,86 & 1,46 & 1,12 \\
\hline Total Geral & 100 & 100 & 100 & 100 & 100 & 100 & 100 & 100 & 100 & 100 \\
\hline
\end{tabular}

Fonte: Gasques et al. (2000) 
A tabela 4 ilustra a evolução das várias fontes de financiamento, onde fica evidenciada a drástica redução dos recursos advindos do Tesouro Nacional (26,72\% em 1990 e 0,02\% em 1999), e o crescimento da participação de fontes como FAT - Fundo de Amparo ao Trabalhador (11,29\% em 1999), Poupança Rural (12,18\% em 1999) e BNDES/FINAME, a partir de 1997 começou a financiar a atividade agrícola (3,38\%) e quase dobrou o volume de recursos ao final da década (6,26\%). Gasques et al. (2000) chamam a atenção para a importância dos recursos do BNDES/FINAME, pois estes são alocados para investimento no setor rural, que praticamente havia sido esquecido nos últimos anos.

\subsection{As falhas do sistema atual}

O fato do volume de financiamentos estar, em média, ano a ano se reduzindo mostra que o atual sistema de financiamento perdeu em eficiência. Além do mais, os volumes de crédito estão muito aquém do necessário para promover o desenvolvimento agrícola do país.

De acordo com Gasques et al. (2000), a explicação mais utilizada para a decrescente quantidade de recursos ofertados pelo Sistema Nacional de Crédito Rural é o esgotamento do sistema, que se apóia em fontes que não são capazes de suprir a necessidade de recursos.

Pessoa (1996) argumenta que a agricultura, após anos de desequilíbrio macroeconômico, sofreu uma drástica redução de recursos destinados ao crédito rural como consequiência das transformações pelas quais passou o sistema financeiro brasileiro, e todos os sistemas produtivos do país, durante o período de inflação elevada. A evolução crescente, nos anos 80, do déficit fiscal fez com que o governo tivesse sua capacidade de poupança reduzida, o que o forçou a buscar financiamento junto ao setor privado. Para Pessoa (1996), o financiamento do déficit público com recursos do setor privado redirecionou a poupança doméstica em detrimento do financiamento das atividades produtivas, especialmente da agricultura cuja atividade possui riscos mais elevados e ciclo produtivo mais longo se comparada com as demais atividades produtivas. 
As principais fontes de recursos mais utilizadas pelo Banco do Brasil, nos últimos anos, têm sido a Poupança Rural e o FAT, o que gerou um total de R\$ 6.654 milhões em operações de custeio, investimento e comercialização em 1999. No entanto, a saída das aplicações de Recursos Obrigatórios afetou a oferta total do Banco do Brasil e reduziu em cerca de $\mathrm{R} \$ 300$ milhões o volume de crédito de todo o sistema nacional (Gasques et al., 2000).

Os recursos provenientes de equalizações de juros (dispêndios realizados pelo governo à conta do Tesouro Nacional para a execução de políticas e programas da agricultura como política de crédito rural, política de preços mínimos, PRONAF entre outras) se reduziram em 1999 por volta de $38 \%$ em termos nominais. Gasques et al. (2000) atribuem esta queda a um problema de oferta e demanda de crédito. Do lado da oferta os bancos utilizaram apenas parcialmente os limites equalizáveis autorizados e, como a dotação foi superior à execução (fato que vem ocorrendo nos últimos três anos), provavelmente ocorreu um problema de falta de demanda de crédito pelo sistema bancário. Tal fato pode ser justificado à maior seletividade dos bancos na distribuição dos financiamentos, além do enfraquecimento da demanda por recursos do crédito rural devido a problemas de juros altos e de garantias (Gasques et al., 2000).

A Resolução N 2822 de 1988 criou a 63 - Rural com o objetivo de gerar recursos via aplicações em crédito rural (agrícola e pecuário), crédito agro-industrial e em títulos públicos. Entrevistas realizadas por Gasques et al. (2000) mostraram que esses recursos foram muito pouco utilizados em função dos elevados encargos financeiros, do crédito rural e agro-industrial, superiores a $20 \%$ ao ano para os usuários. Gasques et al. (2000) ainda argumentam que a cláusula de correção cambial reduziu a atratividade dessa fonte a partir da desvalorização cambial ocorrida em janeiro de 1999. Estima-se que os encargos financeiros para empréstimos concedidos fora do Sistema Nacional de Crédito Rural, como adiantamentos de contratos de câmbio e títulos de contratos futuros (CPR, por exemplo) cheguem a 30\%, custo esse que se defronta com uma demanda de crédito rural muito elástica, além do alto endividamento de grande parte dos produtores rurais (Araújo, 1999). 
Santiago \& Silva (1999) defendem a idéia de que as alterações nas regras e condições de operação do crédito rural, após diversos planos de estabilização econômica, associados ao desempenho da renda agrícola elevaram substancialmente o endividamento e inadimplência do setor agropecuário. Esse quadro aumenta sobremaneira as dificuldades dos agricultores em obter financiamentos formais, de forma que as operações realizadas fora do sistema financeiro e do controle do governo (chamadas de crédito informal) passam a ganhar mais importância, especialmente para os agricultores de pequeno porte. No entanto, é indiscutível que o endividamento dos produtores tornou-se uma barreira muito forte ao autofinanciamento do setor rural, o que torna ainda mais necessário uma política de crédito rural mais eficiente, a dívida total da agricultura junto ao Sistema Nacional de Crédito Rural (SNCR) equivale a aproximadamente R\$20,6 bilhões, ou a um quarto do PIB agropecuário (Araújo, 1999).

A CPR - Cédula do Produto Rural, concebida pela Lei n ${ }^{\circ} 8.929$ de 22/08/94, é resultado da pressão por novas fontes de financiamento para a agricultura. As operações de troca envolvendo a venda antecipada da produção, especialmente com soja, teve início no final dos anos 80 , época em que tal método era considerado por produtores e cerealistas da região de cerrado, a melhor forma de viabilizar recursos para a produção (Pimentel, 2000).

Ainda que se apresente como uma fonte atrativa de crédito, segundo alguns autores já existe no mercado um volume de aproximadamente R $\$ 4$ bilhões de CPRs de gaveta (CPRs que não passam pelo sistema de aval do Banco do Brasil). Pimentel (2000) destaca que alguns aspectos precisam ser melhorados para se garantir maior eficiência e menor risco dessas operações: i) aspectos jurídicos e escriturais, pois, constata Pimentel (2000), que a impunidade existente nas ações de má fé, mesmo quando comprovadas, pode levar ao descrédito do sistema; ii) dados estatísticos para as seguradoras, que ainda são insuficientes para as seguradoras garantirem um prêmio e cobertura estabelecidos em bases mais realistas e viáveis para o produtor; iii) sistema integrado de informações.

Tanto as CPRs, como os modelos de gestão de risco para a produção agrícola ainda estão poucos desenvolvidos no Brasil, no entanto, existe um potencial de 
desenvolvimento muito grande para este tipo de atividade, e que pode se tornar na grande fonte de financiamento da atividade rural no Brasil. No entanto, deve-se destacar que as altas taxas de juros (como resultado da âncora monetária do Plano Real) praticadas no mercado de capitais, inviabilizam esse tipo de atividade, uma vez que encarecem demais os custos de operação.

Para Araújo et al. (2001) o atual estágio de desenvolvimento da agricultura brasileira exige que a atividade produtiva seja financiada através de uma combinação entre recursos próprios dos produtores (auto-financiamento), e captações junto ao mercado financeiro. Para viabilizar esse sistema, que se utiliza do capital via bolsas de físicos e de futuros, é necessário uma reestruturação do setor financeiro, além de formação e treinamento técnico dos agentes interessados em operar com essa forma de capital. E, ainda, talvez a questão mais importante: a conjuntura macroeconômica do país tem que se alterar. Com uma taxa básica (SELIC) de juros em torno de 19\% tornase impossível para o produtor qualquer forma de captação de recursos junto ao mercado financeiro, não só no que se refere ao risco da agricultura, como também em relação à rentabilidade do setor agrícola.

\subsection{Novas propostas em questão}

Por todos os estudos recentes sobre crédito rural no Brasil, pode-se concluir que o sistema formal de financiamento, baseado em taxas de juros subsidiadas (taxa de juros nominal não corrigida pela taxa de inflação), está fadado à extinção, ou pelo menos será restrito aos pequenos agricultores e regiões mais carentes do país, caso do PRONAF (Programa Nacional da Agricultura Familiar).

Araújo (1999) discute a participação (crescente) dos mercados informais, o que indica que a mesma vem crescendo rapidamente a partir do final dos anos 80 . Certamente, atesta Araújo (1999), no novo padrão de financiamento da agricultura ocorrerá uma reavaliação e valorização das funções do financiamento informal.

Araújo et al. (2001) destacam três propostas como promissoras de um novo modelo de financiamento da agricultura: criação de um fundo fiscal que capte recursos do próprio setor agrícola; ampliação das linhas de recursos externos (via política cambial 
adequada); e maior participação de títulos mercantis relacionados aos mercados físico e de futuros. No entanto, deve-se ressaltar mais uma vez, qualquer que seja o novo modelo de financiamento, somente será viabilizado em um cenário macroeconômico com taxas de juros bem inferiores aos 19\% dos dias de hoje, o que não parece provável no curtoprazo.

\subsubsection{A mudança do paradigma no financiamento rural}

Gasques et al. (2000), baseados em Yaron, Benjamin e Piprek (1999), mostraram que o modelo tradicional de financiamento rural não foi capaz, em diversos países, de aumentar a renda e reduzir a pobreza; além disso, não conseguiu também aproveitar algumas oportunidades, a saber: capacidade de poupança das comunidades rurais, oportunidades de crescimento das pequenas empresas rurais não agrícolas, e possibilidades de diversificação de riscos.

A intermediação financeira rural é vista, por Yaron, Benjamin e Piprek (1999), como medida complementar, além de outras medidas governamentais, para prover o aumento da renda e redução da pobreza no setor rural. Nessa linha de pensamento, o Estado tem papel relevante como agente regulador dos mercados financeiros rurais, no entanto restringindo sua participação apenas à regulação desse mercado.

$\mathrm{Na}$ concepção de Gasques et al. (2000), a principal alteração no conceito de financiamento agrícola diz respeito às fontes de recursos e aos subsídios (como mostra a tabela 5). No paradigma antigo, os financiamentos eram obtidos via governo ou doações, enquanto que os subsídios eram elevados em função de baixas taxas de juros fixadas para os empréstimos. Considerando-se o novo paradigma, os financiamentos serão resultado de depósitos voluntários, e os subsídios serão muitos pequenos ou inexistentes. 
Tabela 5. Comparação entre o velho e novo paradigma de financiamento rural.

\begin{tabular}{lll}
\hline & \multicolumn{1}{c}{ Paradigma Velho } & \multicolumn{1}{c}{ Paradigma Novo } \\
\hline Definição do Problema & Imperfeições de mercado & \multicolumn{1}{c}{ Elevados riscos e } \\
custos de transação
\end{tabular}

Fonte: Gasques et al. (2000)

\subsubsection{Propostas ainda discutidas no Congresso Nacional}

Várias propostas estão sendo apreciadas pelo Congresso Nacional (resumidas no quadro 1), porém nenhuma delas chega a representar uma nova proposta de financiamento da agricultura. Algumas delas (Lei 2137, 3182 e 2858) sugerem que sejam destinados recursos à agricultura através de emissões de moeda, ou a partir de recursos advindos do Orçamento da União. Levando-se em consideração tudo o que foi discutido até aqui, neste trabalho, tais propostas representam um retorno ao modelo 
tradicional de crédito, e por isso devem ser totalmente descartadas. As leis 26 e 197 destacam o apoio à agricultura familiar e à reforma agrária. Os projetos 3107 e 3329, por sua vez, se concentram em novos instrumentos de crédito rural como, por exemplo, a CPR - Cédula do Produto Rural que representam uma modernização do sistema de crédito rural. 


\begin{tabular}{|c|c|c|c|}
\hline Data & Documento & Ementa & Posição Atual \\
\hline 31.10 .91 & $\begin{array}{c}\text { Projeto de Lei } \\
2.137\end{array}$ & $\begin{array}{l}\text { Cria o Fundo de Apoio à Agricultura - FAG } \\
\text { composto pelas seguintes fontes: } 45 \% \text { de } \\
\text { emissões de moeda; recursos ordinários do } \\
\text { Tesouro Nacional }\end{array}$ & $\begin{array}{l}\text { 24.07.2000 - Solicitado pela Mesa } \\
\text { Diretora a Reconstituição do Projeto }\end{array}$ \\
\hline 02.09 .92 & $\begin{array}{l}\text { Projeto de Lei } \\
3.182\end{array}$ & $\begin{array}{l}\text { Institui o Fundo Especial de Apoio aos } \\
\text { Pequenos Produtores Rurais e Agricultores } \\
\text { Assentados, Cooperativados ou Associados, } \\
\text { e dá outras providências }\end{array}$ & $\begin{array}{l}\text { 20.09.2000 - Encaminhado para Comissão } \\
\text { de Finanças e Tributação para emissão de } \\
\text { parecer }\end{array}$ \\
\hline 13.03.97 & $\begin{array}{l}\text { Projeto de Lei } \\
2.858\end{array}$ & $\begin{array}{l}\text { Dispõe sobre a destinação de percentual dos } \\
\text { Fundos Constitucionais de Financiamento } \\
\text { das regiões Norte, Nordeste e Centro-Oeste, } \\
\text { para financiar as atividades produtivas de } \\
\text { agricultores de base familiar, e dá outras } \\
\text { providências }\end{array}$ & $\begin{array}{l}\text { 10.10.1999 - Encaminhado à Comissão de } \\
\text { Constituição e Justiça e de Redação para } \\
\text { emissão de parecer }\end{array}$ \\
\hline 27.04.99 & $\begin{array}{c}\text { Projeto de Lei } 26 \\
\text { (complementar) }\end{array}$ & $\begin{array}{l}\text { Institui o Fundo de Aval de empréstimos a } \\
\text { Agricultores Familiares - FUAVAL, altera } \\
\text { dispositivo da Lei } 7.689 \text { de } 15.12 .88 \text {, e dá } \\
\text { outras providências }\end{array}$ & $\begin{array}{l}\text { 13.09.2000 - Encaminhado à Comissão de } \\
\text { Agricultura e Política Rural (CAPR) para } \\
\text { emissão de parecer }\end{array}$ \\
\hline 03.03.99 & $\begin{array}{c}\text { Projeto de Lei } \\
197 \\
\text { (Senado Federal) }\end{array}$ & $\begin{array}{l}\text { Nova redação ao art. } 52 \text { da Lei } 8.171 \text { de } \\
17.01 .1991 \text {, que dispõe sobre a política } \\
\text { agrícola. Beneficiários são os agricultores } \\
\text { familiares e assentados em área de reforma } \\
\text { agrária }\end{array}$ & $\begin{array}{l}\text { 04.03.1999 - Encaminhado ao } 1^{\circ} \\
\text { Secretário para revisão, nos termos do Art. } \\
65 \text { da Constituição Federal }\end{array}$ \\
\hline 23.03.99 & $\begin{array}{c}\text { Proposta de } \\
\text { Emenda à } \\
\text { Constituição } 42\end{array}$ & $\begin{array}{l}\text { Dispõe sobre a municipalização da } \\
\text { agricultura e dá outras providências }\end{array}$ & $\begin{array}{l}\text { 11.08.1999 - Encaminhada à Comissão de } \\
\text { Constituição e Justiça e de Redação para } \\
\text { emissão de parecer }\end{array}$ \\
\hline 2000 & $\begin{array}{l}\text { Projeto de Lei } \\
\text { 3.107/2000 }\end{array}$ & $\begin{array}{l}\text { Fixa em } 40 \text { UFIR 's o valor dos } \\
\text { emolumentos cobrados pelo registro da } \\
\text { Cédula do Produtor Rural no Cartório de } \\
\text { Registro de Móveis, conforme estabelecido } \\
\text { na Lei } 8929 \text { de } 22.08 .1994 \text { que institui a } \\
\text { CPR, representativa de promessa de entrega } \\
\text { de produtos rurais, com ou sem garantia } \\
\text { cedularmente constituída e legitima o } \\
\text { produtor rural, suas associações ou } \\
\text { cooperativas, para a sua emissão }\end{array}$ & $\begin{array}{l}\text { 11.08.2000 - Encaminhado para } \\
\text { apreciação da Com. De Agricultura e } \\
\text { Política Rural (CAPR) para emissão de } \\
\text { parecer }\end{array}$ \\
\hline 2000 & $\begin{array}{c}\text { Projeto de Lei } \\
3.329\end{array}$ & $\begin{array}{l}\text { Altera o Dispositivo do DL } 167 \text { de } \\
14.02 .1967 \text {, que "dispõe sobre títulos de } \\
\text { crédito rural e dá outras providências", e da } \\
\text { Lei } 8.929 \text { de } 22.08 .1994 \text {, que institui a CPR, } \\
\text { e dá outras providências }\end{array}$ & $\begin{array}{l}\text { 29.06.2000 - Anexado ao Projeto de Lei } \\
\text { 3017/00 para apreciação conjunta }\end{array}$ \\
\hline
\end{tabular}

Quadro 1 - Propostas em discussão no Congresso Nacional sobre crédito rural.

Fonte: Gasques et al. (2000) 


\subsubsection{A Proposta da Tendência Consultoria Integrada}

Guedes Filho (1999) apresenta a proposta da Tendência Consultoria Integrada (ilustrada na figura 3) não como um trabalho que visa a criação de um novo sistema de financiamento agrícola, mas uma proposta de caráter geral "apontando as principais linhas do que pode ser feito". Uma constatação imediata do autor é que o Brasil deve dispensar um sistema cooperativista, predominante na Europa e na fase de distribuição de recursos nos EUA, uma vez que o Brasil não possui "mentalidade associativista". A exemplo do sistema norte-americano, Guedes Filho (1999) sugere o crescimento da participação de fornecedores de insumos e tradings no fornecimento de crédito.

Em um novo sistema, voltado apenas ou principalmente para o financiamento privado, a CPR é um instrumento fundamental que, para atender às necessidades da agricultura de maneira eficiente, deve ser combinada com a participação de fornecedores de insumos e tradings. Nesta proposta o produtor obterá recursos com a venda futura do produto, ou seja, a emissão de uma CPR, ou por um fornecedor de insumo agindo em cooperação (ou não) com uma instituição financeira. A fim de estimular o produtor a realizar a venda antecipada, propõe-se que a CPR tenha seguro de crédito e de safra negociado com uma seguradora, além de um mecanismo de seguro de preços realizado mediante a compra e venda de opções em mercados futuros, que garanta ao produtor um prêmio por eventuais altas de preço (Guedes Filho, 1999).

A Tendência Consultoria Integrada ainda sugere que o risco cambial seja administrado via mercados futuros, sendo as operações padronizadas por bancos e corretoras de modo a serem acessíveis ao produtor. Depois de avalizada e garantida, a CPR será comprada por uma "Companhia de Securitização Agrícola", e servirá de lastro para o lançamento de títulos não vinculados a produtos, produtores e regiões específicas. Os autores da proposta sugerem o nome de Bônus da Agricultura Brasileira ou Certificado de Recebíveis Agrícolas.

A idéia central do sistema proposto é reduzir o risco do setor, pois como mostra Guedes Filho (1999), estando ligado à venda antecipada da produção haverá maior utilização do mercado de futuros como mecanismo de produção. A participação do 
governo, nesse sistema, restringe-se ao uso da poupança rural aos pequenos agricultores e regiões mais carentes, que não podem usufruir os instrumentos de mercado.

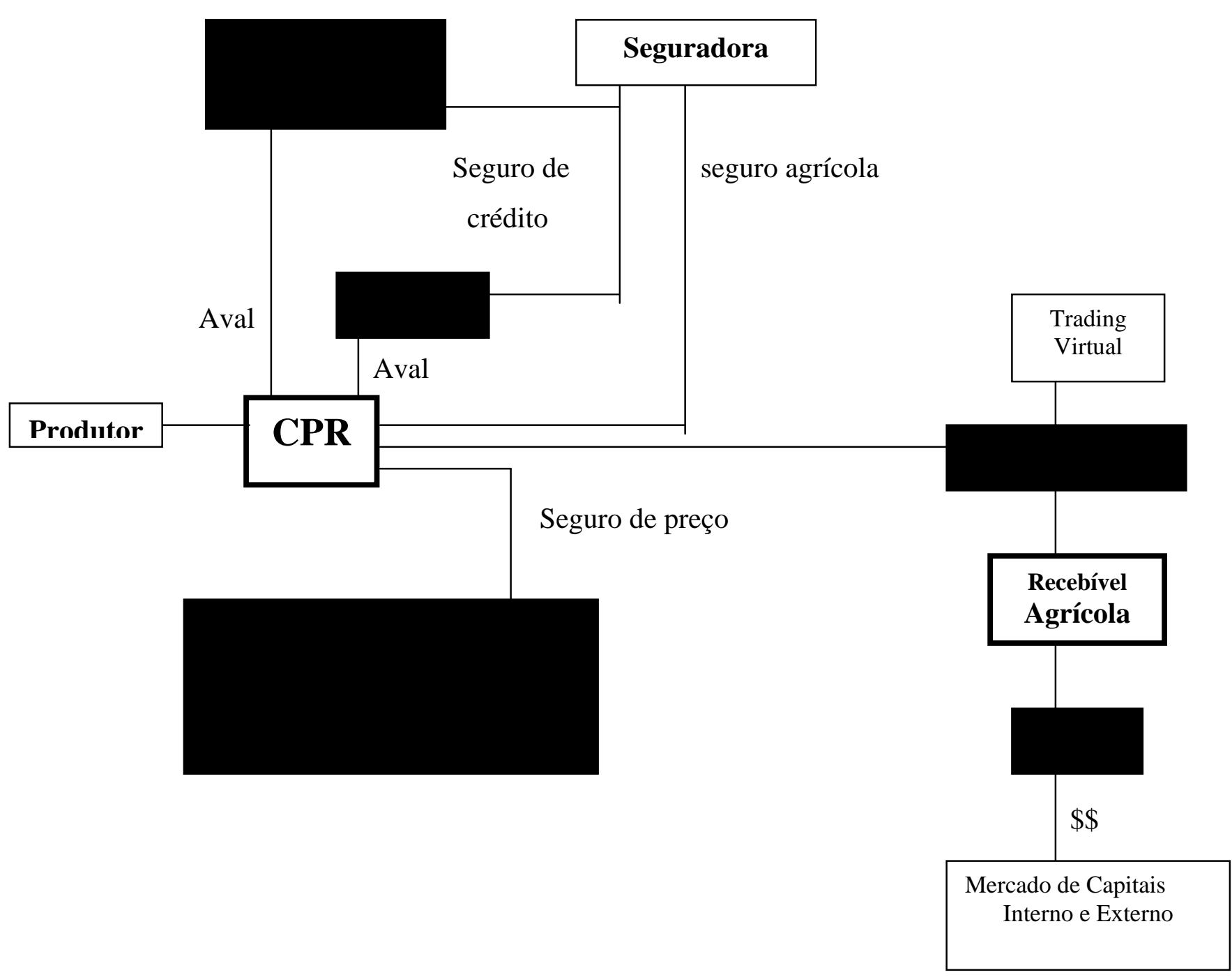

Figura 3 - Proposta da Tendência Consultoria Integrada.

Fonte: Guedes Filho (1999)

Para Gasques et al. (2000) a proposta da Tendência Consultoria Integrada teve como importante contribuição no avanço de instrumentos já existentes, especialmente em relação à CPR, a possibilidade de "ampliar o espectro de investidores", uma vez que ocorre a possibilidade de liquidação financeira da CPR. 
Outra contribuição da proposta em questão, analisado por Gasques et al. (2000), é a questão da relevância do sistema de seguro, pois a redução dos custos da fiança bancária tornaria bem menos onerosos os mecanismos da CPR, uma vez que o sistema de seguro consegue diluir pelo sistema os riscos atualmente concentrados sobre os produtores.

Deve-se ressaltar, no entanto, que a proposta apresentada por Guedes Filho (1999) possui algumas limitações que devem ser analisadas ao se discutir novos instrumentos de financiamento agrícola. Em primeiro lugar a proposta limita-se à Cédula do Produto Rural (CPR) que, embora tenha crescido nos últimos anos, é um mercado pouco abrangente e que, até o momento, beneficiou apenas os produtos de comércio exterior ou comercializáveis no mercado internacional (como soja, café, laranja), não abrangendo produtos de mercado doméstico pouco ou nada comercializados internacionalmente (casos de batata, feijão, mandioca, verduras, milho entre outros). Grande parte da produção agrícola brasileira é composta por produtos muito pouco contemplados por mercados futuros agrícolas, de forma que a solução de mercados futuros não se aplica., o que é um fator limitante ao escopo da proposta.

Outro fator limitante da proposta de Guedes Filho (1999) é a pouca liquidez do mercado financeiro brasileiro. Alguns produtos, como soja, conseguem alguma liquidez porque há agentes interessados em fazer hedge, tanto compradores como vendedores do produto (Jayo \& Saes, 1996). Deve-se destacar também a concorrência, desvantajosa para o Brasil, dos mercados futuros internacionais e a tradição brasileira de regulamentar e taxar operações financeiras, que elevam sobremaneira os custos de corretagem, afugentando especuladores e reduzindo a liquidez do mercado.

Destaca-se, ainda, o fato de que é limitada a informação por parte do setor agrícola sobre o funcionamento e sobre a existência do mercado de futuros como alternativa de financiamento, ou seja, são poucos os dados estatísticos disponíveis para as seguradoras (o que eleva a assimetria de informação do mercado, e os custos de transação) e inexistência de uma estrutura jurídica adequada para o desenvolvimento do mercado (no caso, punições para as ações de má fé). Finalmente, alertamos para o âmbito macroeconômico, caracterizado pela âncora monetária de juros altos, que 
impossibilita qualquer obtenção de recursos, para o produtor rural, junto ao mercado financeiro nas atuais circunstâncias econômicas brasileiras.

\subsubsection{A proposta do prof. Guilherme Dias}

Em palestra proferida no ano 2000 no Ministério do Desenvolvimento Agrário, o Prof. Guilherme Dias apresentou uma proposta de financiamento da agricultura que, para Gasques et al. (2000), amplia a abrangência da proposta da Tendência Consultoria Integrada, pois "tem um forte componente voltado para a pequena produção ou setor familiar da agricultura".

$\mathrm{Na}$ visão do Prof. Guilherme Dias, não existe mais capacidade ociosa da produção agrícola, ou seja, não existe fator de produção sub-utilizado, além de ser mais difícil expandir a produção em um cenário de economia aberta e de forte competição. A constatação do Prof. Guilherme é que o país investe muito pouco na agricultura e "de modo generalizado muito menos em alguns grupos do que em outros"; no entanto, para aumentar a produção tornam-se necessários maiores investimentos.

De acordo com Dias $(2000)^{6}$ é preciso, também, que ocorra uma reforma do sistema financeiro, a fim de que este cumpra algumas funções para o desenvolvimento do setor agrícola. O sistema financeiro brasileiro tem uma capilaridade muito baixa; segundo Dias (2000) ele consegue alcançar cerca de 3 a 4 mil unidades produtivas com mais de $50 \%$ de crédito e de outros 700 mil dividindo o restante. Enquanto isso, em outros países, há sistemas que conseguem atingir de 2 a 2,5 milhões de unidades produtivas. Não resta dúvidas de que o sistema agrícola brasileiro precisa de um sistema financeiro novo, eficiente, e de baixo custo.

Na concepção de Dias (2000) investimento é "a decisão do produtor de imobilizar o seu capital durante dez ou quinze anos". O principal entrave do sistema atual de financiamento do investimento agrícola é a distribuição do risco dentro da estrutura de intermediação financeira. A participação do setor público torna-se relevante

\footnotetext{
${ }^{6}$ DIAS, G. L. S. Cenários para a agricultura brasileira: reforma do sistema de financiamento. Brasília: Palestra, 2000.
} 
na redistribuição do risco, pois Dias (2000) considera o mercado de capitais atual incapaz de tal tarefa, exceção feita, talvez, ao mercado de CPR.

A falha principal do sistema atual de crédito, apontado por Dias (2000), é a verticalização do processo decisório de distribuição de crédito, concentrada nas agências de bancos comerciais. Para este autor agências locais de crédito representariam uma solução para o sistema, pois além de estar melhor informada sobre as necessidades locais, se mal administrada, pode quebrar e prejudicar a economia da região, porém é incapaz de gerar riscos sistêmicos. Um obstáculo ao estabelecimento dessas agências é a questão cultural, pois é forte dentro da sociedade brasileira o isolamento do grupo rural em relação aos outros grupos, e são poucas as parcerias de sucesso entre o Estado e a sociedade em tais iniciativas. O objetivo fundamental da agência de crédito, na proposta de Dias (2000), é formar uma carteira de crédito que os outros financiarão, não necessariamente com depósitos da própria região. A grande vantagem desse novo sistema seria a possibilidade de expandir a capilaridade do sistema.

Dias (2000) sugere que, durante a fase de transição para implementação do novo sistema, fosse criado um Fundo de Refinanciamento do Crédito Rural, cujos recursos orçamentários seriam obtidos através de captação no mercado financeiro via títulos do Tesouro Nacional. A figura 4 ilustra a proposta de Dias (2000). 


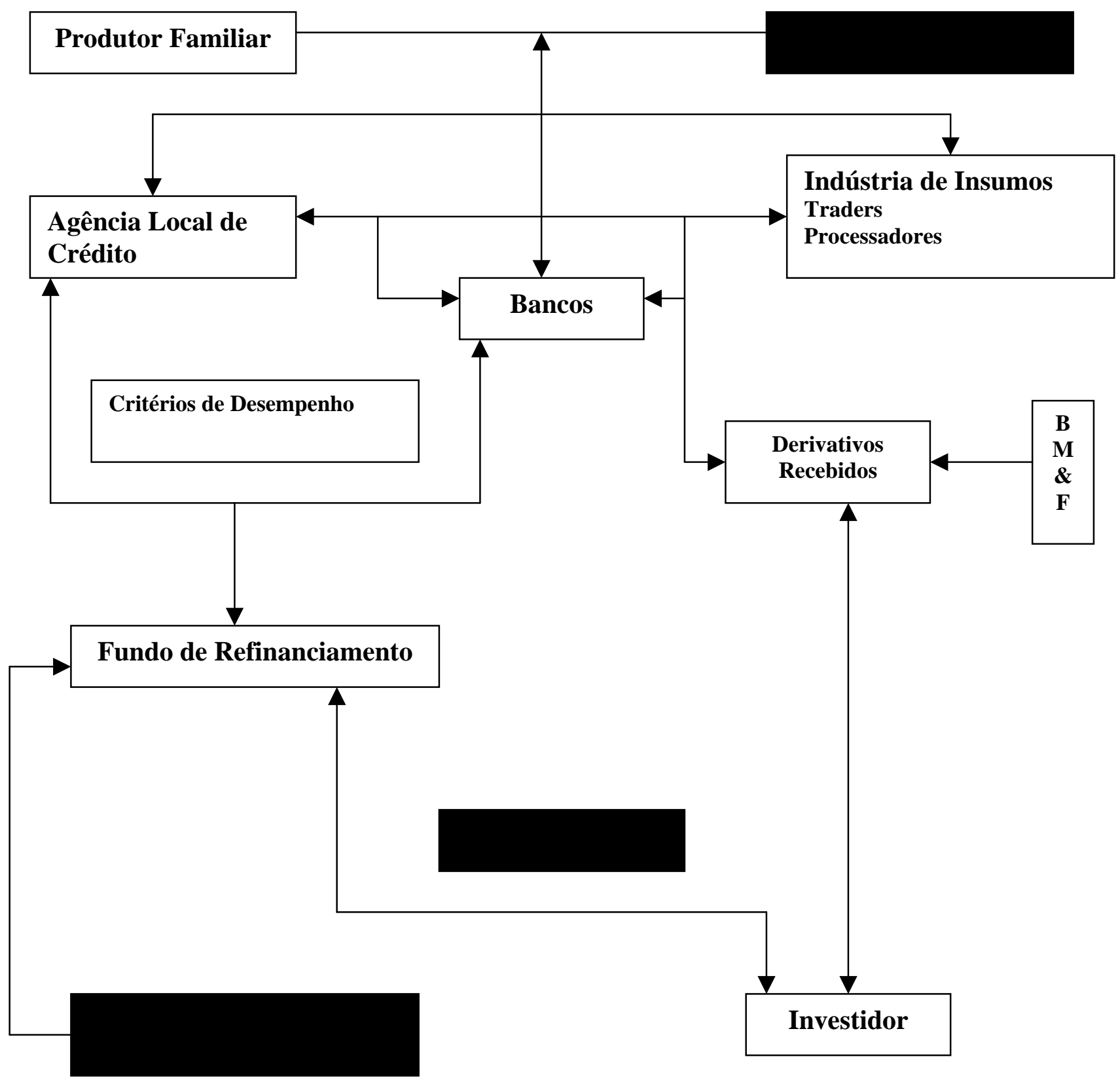

Figura 4 - A proposta do Prof. Guilherme Dias.

Fonte: Dias (2000)

Gasques et al. (2000) verificam que a proposta de Dias (2000), no que se refere ao apoio à agricultura familiar, em muito se assemelha a algumas experiências latinoamericanas, a saber: FINAGRO da Colômbia, e BANDESA da Guatemala. Estes 
projetos têm por objetivo gerar recursos para os produtores com projetos de investimentos viáveis, porém que não possuem recursos para colocá-los em prática.

A proposta do professor Guilherme Dias nos parece mais completa e abrangente que a sugerida por Guedes Filho (1999), porém ela apresenta algumas limitações que consideramos fundamentais, a saber: é dependente de um sistema financeiro acessível e de baixo custo o que, como já discutimos na seção anterior, não ocorre no Brasil; a proposta lida com extremos do setor agrícola brasileiro, ou seja, o pequeno produtor e as grandes empresas agropecuárias, não fazendo menção aos casos intermediários (que certamente representa a maioria dos casos); o próprio autor argumenta que são poucos os casos de sucesso na sociedade brasileira de parcerias entre o Estado e agências locais de crédito, muito em função de uma cultura pouco disposta a associações; e também não possui uma estrutura que, dentro do sistema de mercado, beneficie produtos pouco ou nada voltados para o comércio no mercado internacional.

O grande avanço da proposta de Dias (2000) está em propor um sistema que reduza a assimetria de informação do mercado, em função das agências locais de crédito, o que, portanto, é capaz de fazer com que o sistema funcione com baixos custos de transação e maior eficiência. Outro mérito da proposta está em trazer para o sistema os pequenos agricultores, pois estes possuem maior dificuldade em obter os empréstimos junto aos bancos comerciais e, até o momento, recebem recursos apenas do PRONAF. 


\section{METODOLOGIA}

Este trabalho é de natureza essencialmente analítica, de forma que não foi estabelecido nenhum modelo empírico de teste e análise dos dados apresentados.

Inicialmente realizou-se uma revisão de literatura do crédito rural no Brasil ao longo dos últimos quarenta anos. O objetivo deste levantamento foi obter dados e informações que permitissem a melhor caracterização do sistema criado em 1965, e as principais falhas do sistema que, somadas às transformações ocorridas na economia brasileira como um todo, ao longo do período, terminaram por esgotar o sistema tradicional de crédito rural.

$\mathrm{Na}$ elaboração da série de dados foram utilizados como fonte as publicações do Banco do Brasil, o Boletim do Crédito Rural do Banco Central, o Anuário Estatístico do IBGE, e os dados disponibilizados pelo Ministério da Agricultura.

A análise teórica do mercado de crédito, neste trabalho, contou com uma revisão da literatura de teoria econômica a respeito do assunto nos últimos vinte anos. 


\section{ANÁLISE TEÓRICA DO MERCADO DE CRÉDITO}

\subsection{Características dos mercados agrícolas}

A agricultura, de modo geral, apresenta algumas características que impedem um equilíbrio perfeito de mercado e, conseqüentemente, acabam interferindo no mercado de crédito, a saber:

- Risco climático

- Custos de transação elevados

- Preços voláteis

- Assimetria de informação

Nos anos 50 e 60 o diagnóstico do financiamento rural, nos países em desenvolvimento, indicava que os produtores tinham muito pouco acesso ao crédito formal. Os empréstimos informais possuíam altos custos, uma vez que os juros cobrados pelos prestamistas eram muito elevados, o que tornava o sistema incapaz de financiar os investimentos necessários para o desenvolvimento rural (Meyer \& Nagarajan, 1997).

O crédito é um instrumento particularmente importante para os países pobres, especialmente no que diz respeito ao desenvolvimento econômico, uma vez que garante maior liquidez para investimentos. A utilização eficiente dos recursos financeiros consiste, atualmente, num dos principais fatores que causam as disparidades entre países ricos e pobres, ou seja, um sistema financeiro eficiente é de grande relevância para o crescimento econômico (Banco Mundial, op. cit.)

As instituiçõos financeiras, formais e informais, representam parte da infraestrutura essencial para a operação eficiente dos mercados de crédito, pois, se 
eficientes, facilitam a arbitragem, e auxiliam a evolução de ativos com base em seus retornos futuros.

A expansão do volume de crédito formal, atualmente, depende muito das Organizações Não Governamentais (principalmente em relação ao microcrédito), e da redução dos custos de transação para as instituições financeiras e seus clientes. As instituições financeiras devem alcançar as áreas rurais mais distantes (grande capilaridade do sistema), o que implica um sistema de baixos custos de transação e reduzida assimetria de informação (Meyer \& Nagarajan, 1997).

Conforme Braga (1998), a hipótese central é que o conjunto de informações necessárias à condição ótima de determinadas transações não são disponíveis de forma homogênea entre os agentes (ao menos sem algum custo incluído). Tal pressuposto é conhecido como assimetria de informação, que pode levar os mercados a resultados

diferentes do ponto de ótimo dos modelos neoclássicos. Ainda tem-se que comportamentos oportunísticos podem originar problemas como seleção adversa, dado que um lado do mercado não possui informação perfeita (Akerlof, 1970).

O problema básico, no mercado de crédito, é que as garantias do empréstimo não resolvem o problema da assimetria de informação. Além do mais, ao se introduzir os conceitos de moral hazard e de seleção adversa, aumentam-se os custos de transação para todas as partes envolvidas no empréstimo. Braga (1998) pondera que a possibilidade de comportamentos oportunísticos nas operações de crédito, e o conseqüente aumento dos custos de transação, gera implicações sobre a alocação de recursos ao longo da economia, e fazem com que o mercado de crédito não funcione de maneira eficiente tanto no que diz respeito à intermediação de recursos de acordo com os interesses dos indivíduos envolvidos, quanto à alocação adequada de fundos ao longo da economia.

\subsection{A importância do mercado financeiro}

O mercado financeiro, através da difusão da intermediação financeira, é um instrumento importante que contribui para o desenvolvimento econômico, pois afeta a distribuição de recursos entre setores e grupos da economia. Em geral, a contribuição 
potencial do sistema financeiro ao desenvolvimento da economia está sujeita à quantidade e qualidade de seus serviços e, principalmente, da eficiência com que são realizados. Entre esses serviços destacam-se: serviços de pagamento, captação de poupança, concessão de crédito entre outros. Sem a intermediação financeira os investimentos em unidades de produção ficaria restrito à capacidade de poupança do produtor ou, ainda, a mecanismos como autofinanciamento e escambo que impedem a especialização da produção (Guidetti \& Araújo, 1994).

À medida que o sistema financeiro consegue captar mais poupança, maior é a expansão da atividade financeira. $\mathrm{O}$ bom funcionamento da atividade financeira reduz o custo de transferir recursos dos poupadores para os agentes tomadores de empréstimos, de forma que há um aumento da taxa paga aos poupadores pelo empréstimo, e uma redução da taxa paga aos tomadores de empréstimos.

Limitar o acesso aos serviços de crédito, financiamento, depósito e seguro tornam os mercados financeiros ineficientes, contraindo o desenvolvimento econômico que, no caso de países em desenvolvimento, é particularmente dependente do crédito. Os efeitos perversos de limitação ao crédito são: menor liquidez dos empréstimos, reduzindo o nível de produção; diminuição da segurança alimentar e consumo; aumento das desigualdades de renda (Meyer \& Nagarajan, 1997).

A repressão financeira, caracterizada por juros nominais fixos e decrescentes combinados com inflação alta e crescente, foi estudada por Mackinnon \& Shaw (1973) nas economias em desenvolvimento. $\mathrm{O}$ argumento central é que a repressão financeira, indiscriminadamente, distorce os preços financeiros incluindo taxas de juros e taxa de câmbio, reduzindo a taxa de crescimento real e a dimensão real do sistema financeiro. A conseqüência natural desse processo é o atraso do desenvolvimento econômico (Fry, 1982).

\subsubsection{O papel dos custos transacionais na oferta de crédito}

Guidetti \& Araújo (1994) dividem os custos de transação do mercado de crédito em dois tipos: custo de mobilização de depósitos e custo de concessão de créditos. A mobilização de depósitos se refere a capital, terra e material que são utilizados no 
manuseio de contas de depósitos, documentação, registros e publicação de balanços por parte da instituição financeira. Já o custo de concessão está relacionado ao processamento do empréstimo e gastos com monitoramento e recuperação dos mesmos.

Citando Meyer \& Cuevas (1990), Guidetti \& Araújo (1994) apresentam os principais fatores que explicam a magnitude dos custos de transação como grau de desenvolvimento e maturidade do sistema financeiro (disponibilidade de tecnologias de comunicação e transporte, aparato legal do sistema), o grau de regulamentação do setor (instrumentos de captação e aplicação, taxas, impostos e barreiras à entrada que influenciam na eficiência do setor), e a escala de operação. De maneira geral existem custos para depositantes, investidores e agências governamentais (custos de monitoramento e aplicação).

Tomando como base o modelo de Mackinnon \& Shaw (1973) exposto por Fry (1982), o crédito não é alocado de acordo com a produtividade esperada dos projetos de investimento, mas de acordo com os custos de transação e riscos de default.

Seja a variável $\mathrm{X}$ a quantidade de empréstimos concedidos por unidade de tempo, " $r$ " o custo de tomar emprestado e "i" o retorno gerado pelos empréstimos. A demanda por empréstimos é negativamente inclinada, refletindo a quantidade crescente de investimentos conforme é reduzido o custo dos empréstimos. A oferta de crédito, por sua vez, tem inclinação positiva, pois à medida que o retorno sobre a poupança torna-se superior ao retorno esperado sobre bens reais e investimentos fora do país, ou seja, haverá maior volume de recursos para empréstimos. A figura 5 ilustra a situação em que não existem custos transacionais nem regulamentação de juros, nesse caso ter-se-ia $i=r$, e a quantidade de crédito para o período seria igual a $X$. 


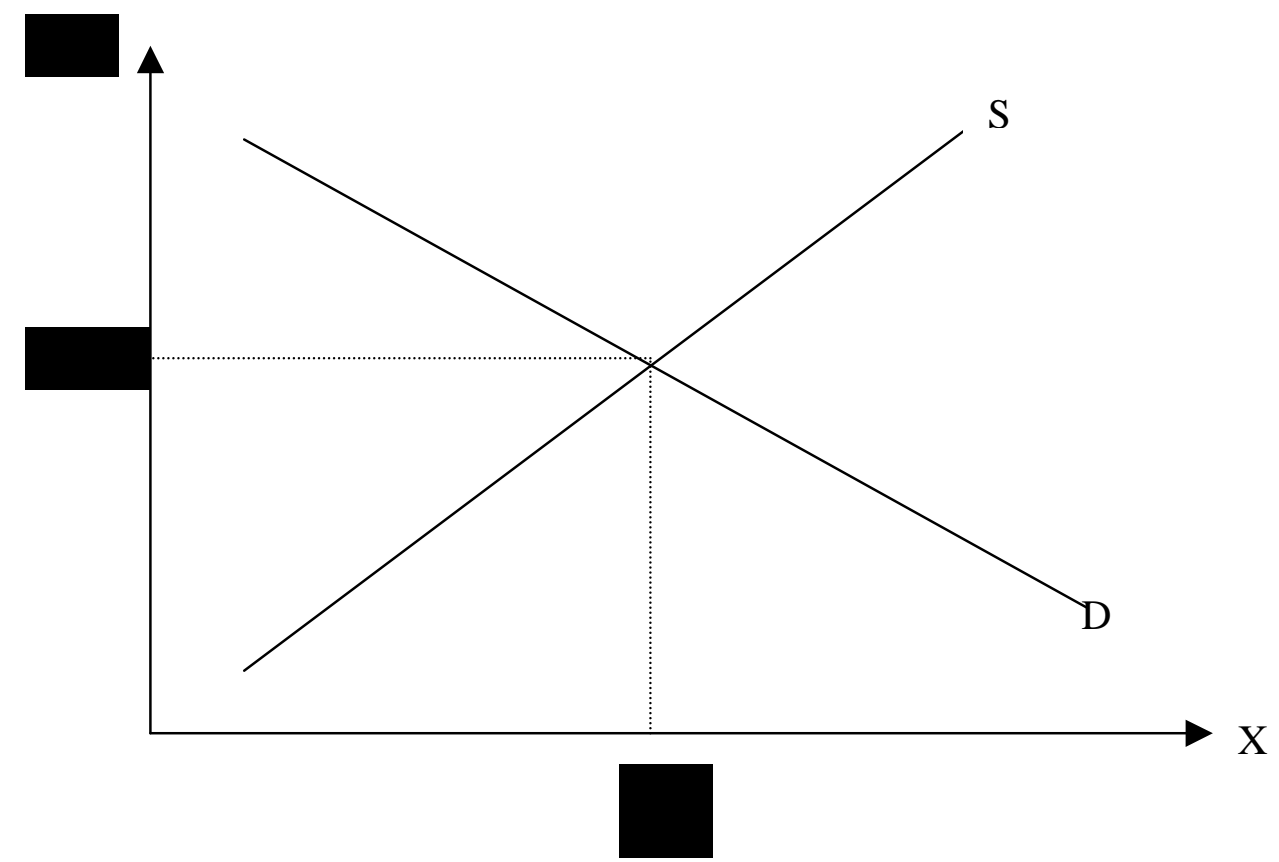

Figura 5 - Equilíbrio no Mercado de Crédito sem Custos Transacionais e Regulamentação de Juros.

Fonte: Relatório do Banco Mundial (1989)

Normalmente existem custos para se determinar a solvência de mutuários que incidem sobre os credores. A reta $S_{d}$, na Figura 6, representa a quantia que os credores têm que cobrar dos mutuários para o ressarcimento dos custos no caso de solvência dos mutuários. A distância vertical entre $S_{d}$ e $S$ (oferta de financiamento) representa o valor dos custos transacionais. Portanto, na ausência de intermediários financeiros, os credores ofertariam $X_{d}$ na expectativa de ganhar id, os mutuários seriam obrigados a pagar $\mathrm{r}_{\mathrm{d}}$ pelo empréstimo, sendo $r_{d}-i_{d}$ o custo de transação da operação. Os serviços prestados pelas instituições financeiras exigem que se colete e processe grande quantidade de informações, além de planejamento, monitoramento dos contratos o que, de certa forma elimina parte da assimetria de informação e reduz os custos de transação dos empréstimos. Se as taxas cobradas pelos bancos são menores que os custo de se emprestar diretamente (entre prestamistas e tomadores de empréstimos), a quantia emprestada aumenta de $X_{d}$ para $X_{b}$, o retorno dos credores aumenta de $i_{d}$ para $i_{b}$, e o 
custo para os tomadores se reduz de $r_{d}$ para $r_{b}$. O equilíbrio do mercado de crédito, para essa situação, é ilustrado pela figura 6.

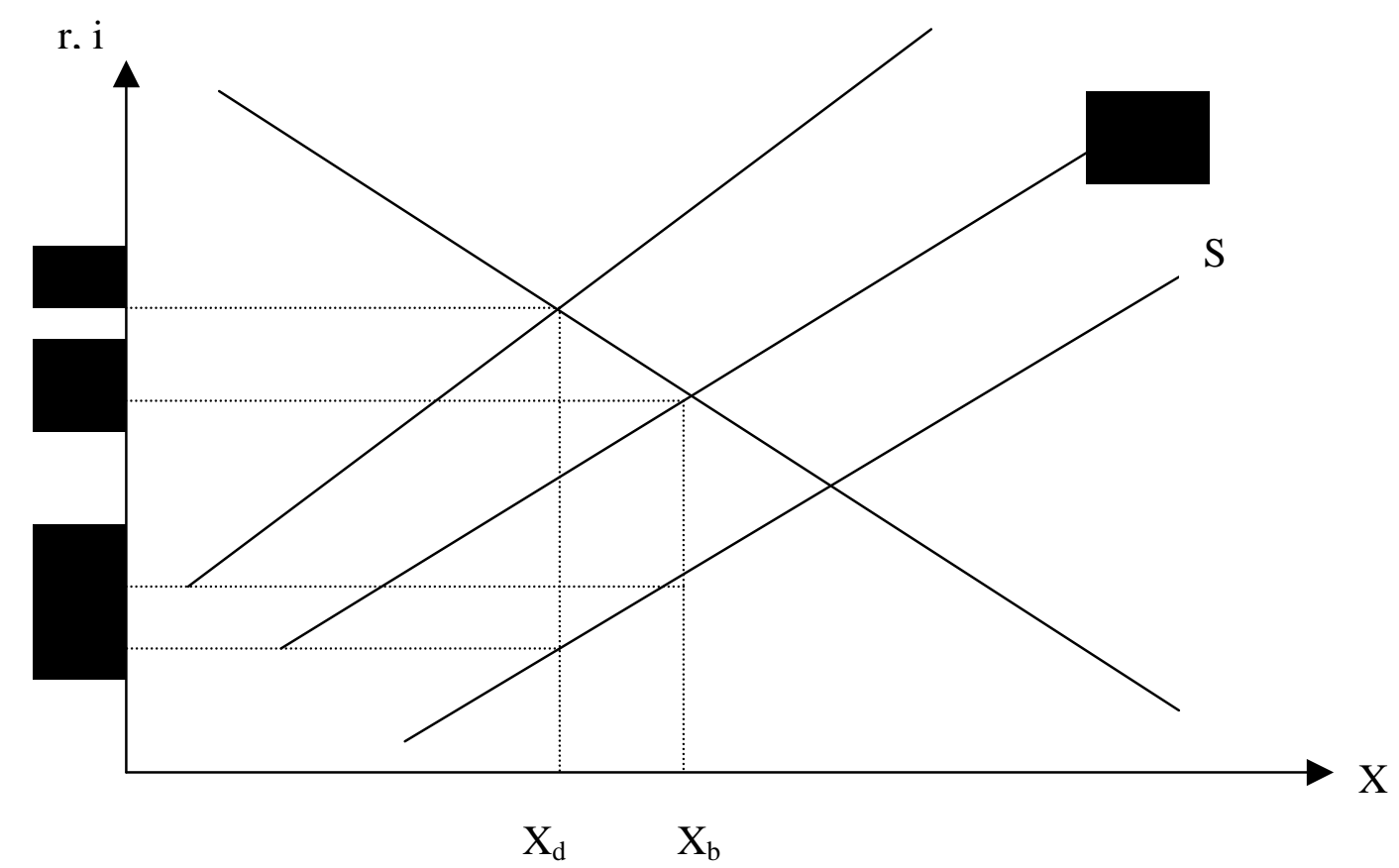

Figura 6 - O Equilíbrio no Mercado de Crédito Considerando-se Custos de Transação e a Presença de Intermediários Financeiros.

Fonte: Relatório do Banco Mundial (1989)

Consideremos, agora, que a taxa de juros seja fixada em $i_{c}$, na Figura 7; quando aplicado às taxas de depósito, $\mathrm{X}_{\mathrm{c}}$ será a quantidade emprestada, e os custos para os mutuários serão de $r_{c}$. No entanto, se a taxa de juros for aplicada às taxas de empréstimos, os bancos fixarão as taxas de depósito em i' ${ }_{c}$, deduzindo os custos de transação, de forma que a quantidade depositada e emprestada (depois de deduzidas as reservas compulsórias) será $\mathrm{X}_{\mathrm{c}}$. $\mathrm{O}$ excesso de demanda de crédito será dado por $\mathrm{X}_{0}-$ $\mathrm{X}_{\mathrm{c}}$, e está ilustrado na figura 7. 


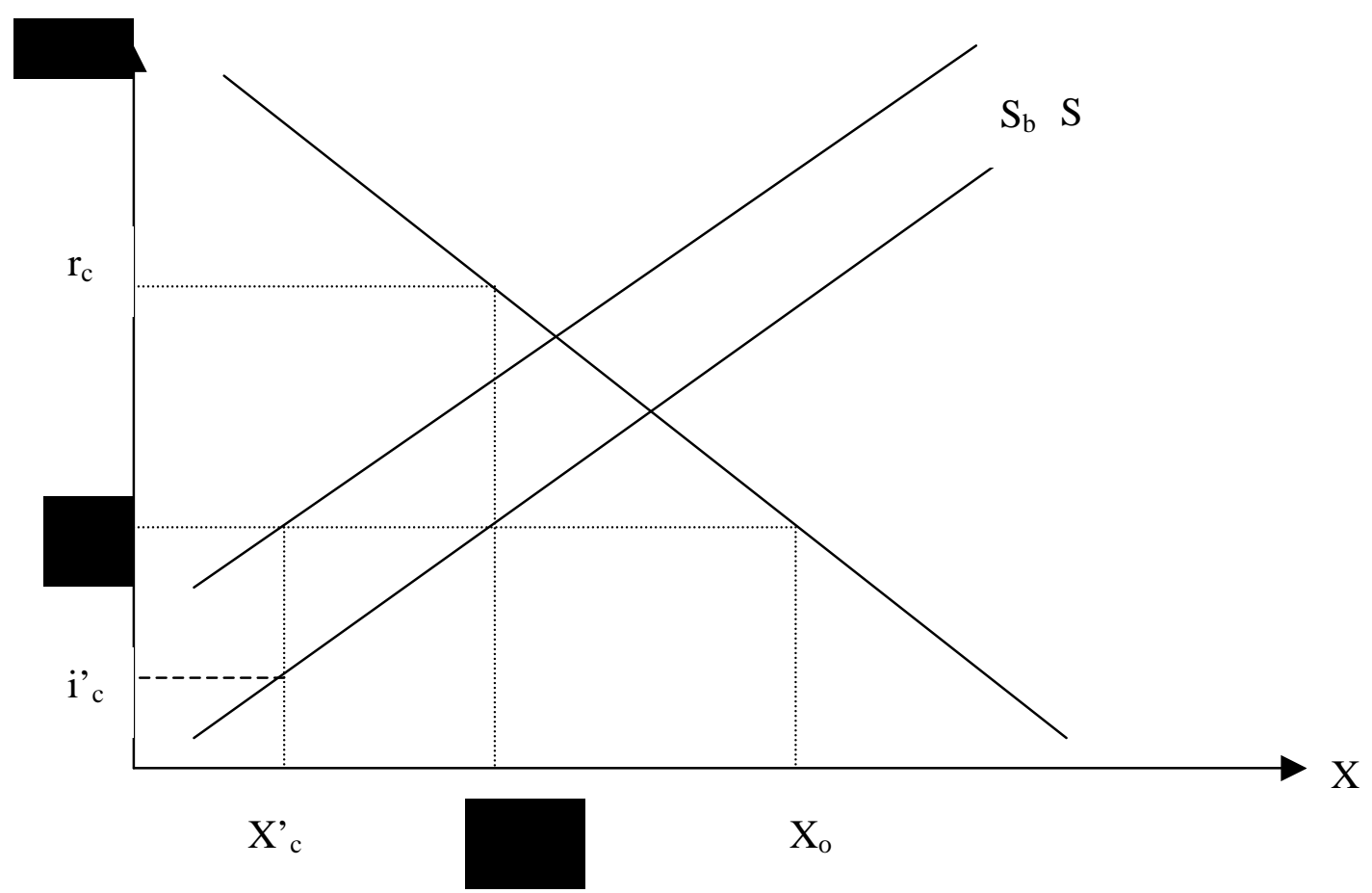

Figura 7 - O Equilíbrio no Mercado de Crédito com Fixação da Taxa Nominal de Juros. Fonte: Relatório do Banco Mundial (1989)

A diferença entre as taxas de tomada e concessão de empréstimos e entre os preços de captação e aplicação demonstram os custos do intermediário financeiro, as perdas esperadas do empréstimo, reservas obrigatórias e tributação (Guidetti \& Araújo, 1994). O custo de transação será proporcional aos custos de informação e os riscos inerentes aos empréstimos para o setor rural.

Os custos de transação totais, segundo Guidetti \& Araújo (1994), podem ser expressos pela seguinte equação:

$$
t=b+d+1+d m+r
$$

onde:

$$
\begin{aligned}
& t=\text { custos totais de transação } \\
& b=\text { custo dos tomadores } \\
& d=\text { custo dos depositantes } \\
& 1=\text { custo dos credores } \\
& \text { dm = custo de mobilização de depósitos } \\
& r=\text { custo de regulação }
\end{aligned}
$$


O tempo de negociação do empréstimo, fornecimento de garantias, custos de oportunidade entre outros referem-se aos custos dos tomadores. Os custos dos depositantes, por sua vez, estão relacionados ao tempo gasto na procura do investimento mais adequado, efetuação de depósitos e retiradas e transporte. A mobilização dos depósitos representa a confecção de documentos, requerimento de reserva na operação financeira e elaboração de seguros do empréstimo. Finalmente, os custos de regulação surgem a partir das operações de controle e supervisão de empréstimos de uma área particular do Banco Central (Guidetti \& Araújo, 1994).

\subsubsection{Os custos bancários de transação do sistema de crédito rural no Brasil: estimativas para os anos 90}

Conforme definição de Meyer \& Cuevas (1990), os custos bancários de transação são determinados pela remuneração dos recursos humanos e materiais utilizados pelas instituições financeiras nas operações de crédito rural durante todo o processo de financiamento, ou seja, a partir do dinheiro tomado junto ao poupador até o vencimento do contrato do empréstimo.

Os custos do intermediário financeiro, destacados por Meyer \& Cuevas (1990), dois outros fatores incrementam tais custos: heterogeneidade dos clientes (o que torna diferente a probabilidade de default entre os tomadores), e informação imperfeita dado que o emprestador, por não conhecer perfeitamente as características dos tomadores, é obrigado a coletar informações e monitorar as atividades de seus clientes.

Barros \& Araújo (1991) estimaram os custos bancários de transação no crédito rural para o Brasil. Os resultados apresentados refletem apenas os custos de aplicação e recuperação do financiamento incorrido pelas agências, sendo três os parâmetros considerados pelos autores para determinar o grau de eficiência nas operações, a saber: o número de contratos, o valor total dos contratos realizados com crédito rural e a proporção das aplicações totais correspondentes ao crédito rural.

Da amostra estudada por Barros \& Araújo (1991), a maioria das agências mostrou um custo bancário de crédito rural entre 0 e 1 unidades monetárias por uma unidade monetária emprestada aos agricultores. Os autores fazem cinco observações a 
partir das estimativas realizadas: i) dado o efeito escala de operação, o emprego de funcionários especializados em operações de crédito rural somente se justifica a partir de um volume mínimo de empréstimos, ou seja, conforme aumenta o volume de empréstimos a divisão de funções torna-se mais eficiente entre os funcionários; ii) a fim de se reduzir custos é necessário reduzir o número de contratos com elevação do valor do empréstimo por contrato; iii) a possibilidade de realocar os funcionários envolvidos com crédito rural em outras atividades das agências em período de baixa demanda também é um fator que interfere na redução de custos; iv) em regiões com muitos pequenos agricultores haverá rigidez na alocação de recursos das agências pois será pequena a escala de operação, e haverá pouca diversificação de operações; v) a política de crédito rural brasileira, via inúmeros regulamentos operacionais, causava elevados custos e baixa eficiência para o sistema bancário.

Guidetti \& Araújo (1994) realizaram estimativas dos custos bancários de transação no Brasil, para o ano de 1993, e para o biênio 1992-1993. Os resultados mostraram que o custo bancário de transação do crédito rural, no ano de 1993, situou-se em $\mathrm{R} \$ 2,5$ por real emprestado. A agência mais eficiente, com custo de $\mathrm{R} \$ 923,07$ por contrato, não trabalhava com funcionários especializados em crédito rural, e $51 \%$ de seus custos eram diretos.

Pelos valores apresentados por Guidetti \& Araújo (1994) não resta dúvidas de que os custos de transação das agências estudadas, como em geral deve se observar em todo o país, estão muito acima do que se verifica em outros países de baixa renda. Os autores apresentam dados que mostram estimativas de custos bancários de transação por unidade monetária de crédito como, por exemplo, Bangladesh (0,9 a 2,9\%), Nigéria (9,5\%), Togo (5,3\%), Filipinas (1,6 a 5,4\%) e Honduras (3,4 a 10\%). Esses dados se referem às diferenças entre as taxas de tomada e de concessão de empréstimos e entre os preços de captação e aplicação, o que acaba sendo os custos dos intermediários financeiros. A figura 8 ilustra o custo real emprestado e o número de contratos por agência no biênio 1992-1993 para a amostra estudada por Guidetti \& Araújo (1994). 


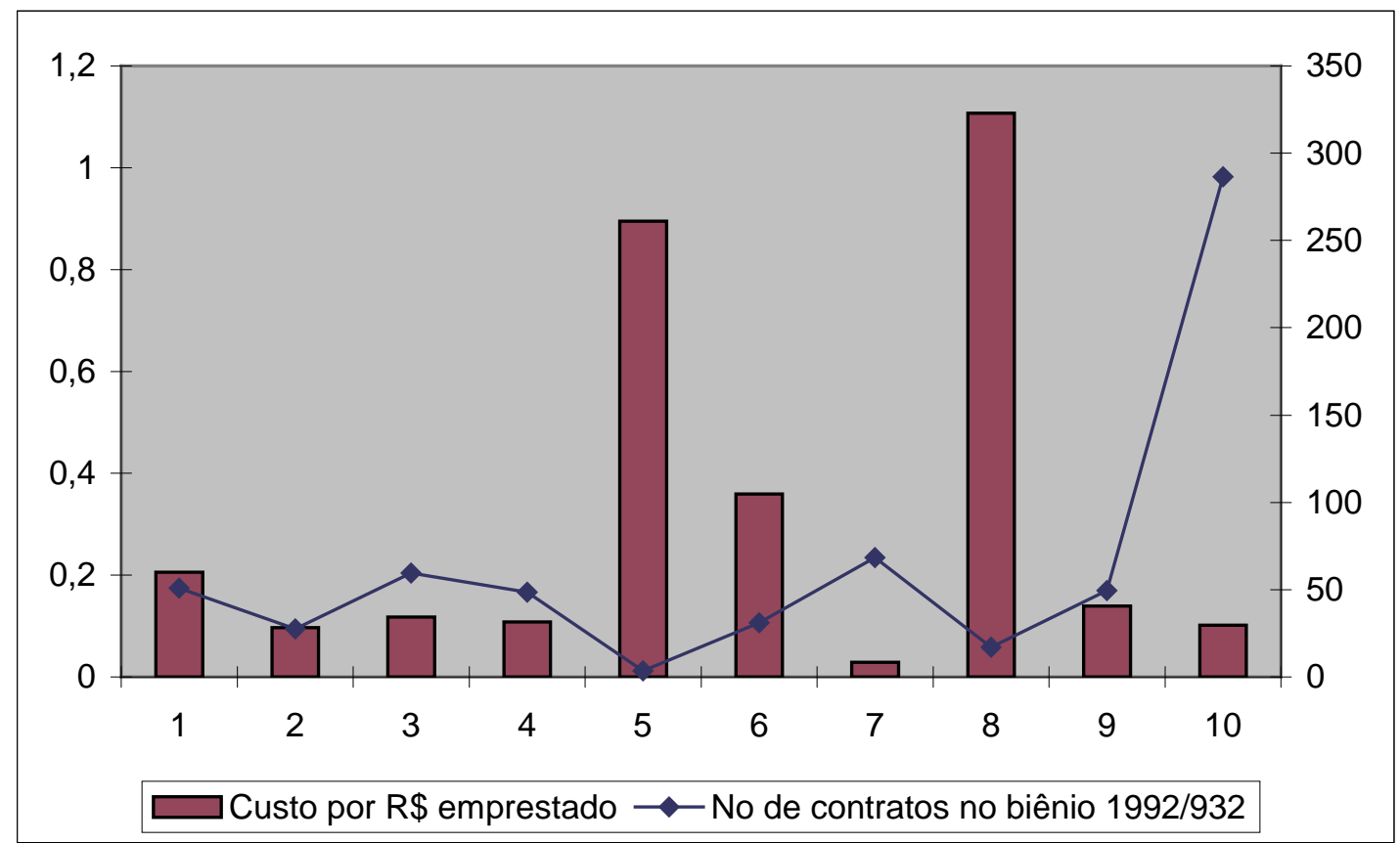

Figura 8 - Custo por Real emprestado e número de contratos no biênio 1992-1993. Fonte: Guidetti \& Araújo (1994)

Na tabela 6 são apresentadas as margens de variação dos custos bancários de transação para as agências amostradas por Guidetti \& Araújo (1994) no ano de 1993, e no biênio 1992-1993. 
Tabela 6. Margem de Variação dos Custos Bancários de Transação por Agência Amostrada para o Ano de 1993 e Biênio 1992-1993.

\begin{tabular}{cc}
\hline Agência & Margem de Variações dos Custos Bancários de transação por Agência (R\$) \\
\hline 1 & $0,2055-0,2853$ \\
2 & $0,0864-0,0967$ \\
3 & $0,1177-0,1669$ \\
4 & $0,1081-0,1122$ \\
5 & $0,8949-2,4937$ \\
6 & $0,3002-0,3597$ \\
7 & $0,0292-0,1413$ \\
8 & $0,6961-1,1068$ \\
9 & $0,1079-0,1395$ \\
10 & $0,0974-0,1020$ \\
\hline
\end{tabular}

Fonte: Guidetti \& Araújo (1994)

A década de 80 representou, para a economia brasileira, um período de pouco crescimento econômico e elevadas taxas de inflação. $\mathrm{O}$ resultado dessa combinação de baixo crescimento econômico e inflação alta foi a redução da participação do setor financeiro na atividade de financiar o setor produtivo que, por sua vez, passou a financiar o déficit do setor público via captação de recursos do imposto inflacionário sobre depósitos à vista. Tal atividade elevou vigorosamente os lucros desse setor que, devido à baixa concorrência e elevados custos operacionais, estabeleceu spreads muito elevados aos tomadores de empréstimo, caracterizando, portanto, um quadro muito desfavorável para a tomada de crédito na economia.

Quando comparam com as estimativas dos custos bancários de transação dos países de baixa renda com as agências contidas em seu trabalho, Guidetti \& Araújo (1994) concluem que os custos bancários de transação do Brasil eram, no período analisado, muito altos. Guidetti \& Araújo (1994) alertam para alguns fatores relacionados à eficiência das operações bancárias de crédito devem ser observadas com 
atenção: i) volume de aplicações do crédito rural (é necessário um volume mínimo de empréstimo por agência, pois à medida que esse volume aumenta a alocação de funcionários especializados torna-se mais eficiente); ii) valor médio por contrato (o ideal seria a redução do número de contratos e aumento do valor do empréstimo para minimizar os custos transacionais) e iii) proporção de aplicações da agência em crédito rural (a demanda por crédito rural é sazonal, em certos períodos a demanda é estacionária de forma que o banco deve ter como opção a alocação de funcionários para outros serviços com demanda mais regular durante o ano).

A política de crédito rural teve, na década de 80 , um período que podemos considerar como um divisor de águas, pois marcou uma fase de redução considerável de recursos públicos destinados ao financiamento da agricultura, haja vista a redução de mais de 30\% no volume de crédito concedido aos agricultores. Também houve uma preocupação do governo em eliminar o subsídio provocado por taxas de juros reais negativas dos empréstimos através do aumento das indexações.

Em um estudo mais recente Pessoa (1996) sustenta que a crise fiscal foi um dos pilares do afastamento do sistema financeiro de sua atividade como financiador das atividades produtivas, pois teve no financiamento da dívida pública, em períodos de inflação alta, sua principal atividade. O grande atrativo do financiamento da dívida pública pelos bancos privados estava no fato de haver uma diferença entre o tempo decorrido da captação de recursos via depósitos à vista, impostos entre outros, e o repasse desses recursos aos credores finais. Os bancos, dado essa diferença de tempo de repasse de recursos, aplicavam o volume de dinheiro captado no over-night e obtinham lucros muito elevados.

Os resultados encontrados por Pessoa (1996) não diferem do que já havia sido constatado, anteriormente, por Guidetti \& Araújo (1996), ou seja, os custos bancários de transação no crédito rural no Brasil continuavam altos e se colocavam, e ainda se colocam, como um dos principais entraves para a reestruturação do sistema de crédito rural no Brasil.

Através de uma amostra de 62 agências de 4 bancos que operam em quatro macroregiões, Pessoa (1996) concluiu que os custos bancários de transação do crédito 
rural no Brasil estão negativamente influenciados pelo longo período de desajuste macroeconômico pelo qual passou a economia brasileira até início dos anos 90 . O autor sugere que a redução desses custos de transação está relacionada à escala de operações das agências, como tamanho da carteira e valor médio dos contratos.

Atualmente não existem sinais de que os custos bancários de transação tenham se reduzido consideravelmente a ponto de permitir um aumento do volume de crédito para a agricultura. Além do mais a inadimplência dos produtores rurais (que até 1988 não ultrapassava 5\% do saldo da carteira rural do Banco do Brasil) atingiu, em 1994, um valor superior a 20\% (Araújo, 1996). Grande parte desse endividamento originou-se devido à defasagem freqüente entre a correção dos preços mínimos e a correção da dívida dos agricultores.

Outro aspecto relevante para a análise da política de crédito é o nível atingido pelas taxas de juros da economia brasileira, especialmente após a implementação do Plano Real, que impedem o produtor rural de contrair qualquer empréstimo junto aos bancos comerciais. A questão dos juros altos será analisada em maiores detalhes na próxima seção.

\subsection{Assimetria de informação, risco moral, seleção adversa e intermediação financeira}

Conforme Araújo (1996) os principais trabalhos teóricos sobre o funcionamento do mercado de crédito surgiram em meados dos anos 80. O enfoque teórico principal, que permeou esses trabalhos, foi a presença de assimetria de informação nos mercados de crédito, ou seja, ofertantes e demandantes de um bem ou serviço não estão perfeitamente informados sobre o que está sendo transacionado no mercado. Caso haja assimetria de informação, os preços não ajustam as diferenças de qualidade entre bens e serviços do mercado, gerando um equilíbrio ineficiente e diferente do que seria o ótimo de mercado (Akerlof, 1970).

O problema de assimetria de informação surge quando certos padrões de comportamento não são perfeitamente observáveis, em uma transação, por todas as partes do mercado sem que haja um custo de informação. Essa possibilidade permite a 
ocorrência de comportamentos oportunísticos (o indivíduo procura tirar proveito da informação sem que seja punido pelos seus resultados) por parte dos agentes que possuem informação não compartilhada com os demais agentes do mercado (Braga, 1998).

Uma solução possível para o problema da assimetria de informação é a intermediação econômica, pois permite a coleta, processamento e ofertar informações (reduzindo o custo agregado de obtenção de informação). Os intermediários econômicos são os agentes que compram bens ou serviços para a revenda, ou ainda, auxiliam na realização das transações.

Especificamente estamos interessados em como o mercado de crédito se ajusta dados os problemas alocativos gerados pela assimetria de informação, a relação contratual entre credores e devedores, e a atuação das instituições financeiras.

Sempre que as instituições financeiras fixarem as taxas de juros em níveis acima do equilíbrio do mercado haverá um incentivo, por parte dos tomadores avessos ao risco, de saída do mercado. Esse movimento fará com que o mercado se concentre apenas entre os tomadores mais propensos ao risco e, conseqüentemente, com maior risco de default.

O risco moral existe quando ocorre o default por parte do tomador; nesse caso o emprestador será ressarcido em apenas uma parte (ou em nada) do volume total emprestado.

Considerando o lado dos emprestadores, a atividade de emprestar vai além da troca de um consumo presente por um consumo futuro, pois antes de se fazer um empréstimo deve-se ter garantido: seguro contra risco de inadimplência, coleta de informações sobre as características dos tomadores de empréstimos e desenvolvimento de mecanismos que maximizem a probabilidade de reembolso do crédito concedido (Araújo, 1996).

Segundo Hoff \& Stiglitz (1990) três são os problemas associados à assimetria de informação no mercado de crédito: i) screening problem ou problema de seleção (a probabilidade de inadimplência é diferente entre os tomadores de empréstimos, o que acaba gerando um custo relativo ao cálculo de risco do devedor); ii) incentive problem 
ou problema de incentivo (as instituições financeiras têm que monitorar as atividades dos tomadores de empréstimo a fim de aumentar a probabilidade de pagamento do empréstimo); iii) enforcement problem que representa as dificuldades em forçar os tomadores de empréstimo a liquidar sua dívida.

\subsubsection{O racionamento como equilíbrio no mercado de crédito}

Quando o mercado vive uma situação em que, dada uma taxa de juros prevalecente, os tomadores de empréstimo recebem menor quantidade de empréstimo que a quantidade demandada diz-se que há um racionamento.

Araújo (1996), com base em Hunte (1993), destaca dois tipos de racionamento de crédito:

tipo I: racionamento quantitativo, ou seja, a quantidade recebida pelos tomadores de empréstimo é menor que a quantidade por eles demandada

tipo II: racionamento qualitativo, que ocorre quando apenas alguns tomadores conseguem o empréstimo, mesmo que as características entre os tomadores que conseguem ou não o empréstimo sejam semelhantes.

Segundo Araújo (1996), até os anos 70, os trabalhos publicados sobre mercado de crédito ignoravam os efeitos da assimetria de informação e a possibilidade de racionamento. A base da literatura que analisa tais feitos, para Araújo (1996), é: Jaffee \& Russel (1976), Keeton (1979), Stiglitz \& Weiss (1981), O’Connell (1984) e Bester (1985).

Os trabalhos acima destacados abordam a questão da assimetria de informação considerando que a variável taxa de juros não explica satisfatoriamente o comportamento do mercado de crédito, pois se é elevada pode atrair tomadores de alto risco de default para o mercado e diminuir o retorno esperado dos emprestadores. Além da variável taxa de juros, o racionamento do mercado de crédito também seria função de problemas como seleção adversa, riscos dos projetos, termos dos contratos de empréstimo, competição entre os bancos e características associadas ao risco de inadimplência (Araújo, 1996). 
Nas próximas seções discutiremos os modelos de Stiglitz \& Weiss (1981) e Driscoll (1991) que, ao nosso ver, são os principais no que se refere ao equilíbrio no mercado de crédito com racionamento, e também o modelo de Hoff \& Stiglitz (1993) que caracteriza, para os países em desenvolvimento, o mercado de crédito rural em uma competição imperfeita.

\subsubsection{O modelo de Stiglitz \& Weiss (1981)}

O trabalho de Stiglitz \& Weiss (1981) foi um dos pioneiros na utilização de assimetria de informação nos mercados de crédito. Em linhas gerais, no modelo de Stiglitz \& Weiss (1981), a seleção adversa é uma conseqüência da assimetria de informação, observada nas taxas de juros cobradas nos empréstimos. O resultado desse modelo é o crédito racionado, com uma taxa de juros menor do que a que equilibraria a oferta e demanda de crédito, pois quanto maior a taxa de juros, maior é a demanda de empréstimo para projetos de alto risco que, no caso de serem bem sucedidos, terão um retorno muito superior aos projetos com menos risco.

Braga (1998) formaliza o modelo de Stiglitz \& Weiss (1981) da seguinte maneira: existem duas firmas com diferentes probabilidades de sucesso e estão dispostas a demandar uma quantia $\mathrm{X}$ para financiar seus investimentos, e nenhuma delas possui colateral (garantias reais oferecidas pelo tomador de crédito).

A firma 1, quando realiza com sucesso seu empreendimento, gera uma receita de $Y_{1}$, ao passo que a firma 2, em situação semelhante, obtém receita $Y_{2}$. Na situação de insucesso, para ambas as firmas, a receita do empreendimento é nula. A probabilidade

de insucesso do empreendimento i é definida como $\mathrm{q}_{\mathrm{i}}$, e supõe-se que $\mathrm{q}_{1}$ é menor que $\mathrm{q}_{2}$, ou seja, a firma 2 é de maior risco se comparada à firma 1(Braga, 1998).

Portanto, o lucro esperado de ambos os projetos é:

$$
\begin{aligned}
& \Pi_{\mathrm{f} 1}(\mathrm{r})=\mathrm{q}_{1} \cdot 0+\left(1-\mathrm{q}_{1}\right) \cdot\left[\mathrm{Y}_{1}-(1+\mathrm{r}) \cdot \mathrm{X}\right] \\
& \Pi_{\mathrm{f} 2}(\mathrm{r})=\mathrm{q}_{2} \cdot 0+\left(1-\mathrm{q}_{2}\right) \cdot\left[\mathrm{Y}_{2}-(1+\mathrm{r}) \cdot \mathrm{X}\right]
\end{aligned}
$$

Uma hipótese fundamental do modelo de Stiglitz \& Weiss (1981) é que, em caso de sucesso, a firma 2 oferece maior retorno. Isso equivale a dizer que $\left(1-\mathrm{q}_{1}\right)$. $\mathrm{Y}_{1}<$ 
$\left(1-\mathrm{q}_{2}\right)$. $\mathrm{Y}_{2}$. Assumindo esta hipótese, para qualquer $\mathrm{r}$, teremos $\Pi_{\mathrm{f} 1}(\mathrm{r})<\Pi_{\mathrm{f} 2}(\mathrm{r})$. Considera-se, agora, $\mathrm{r}^{*}$ e $\mathrm{r}^{* *}$, tal que: $\Pi_{\mathrm{f} 1}\left(\mathrm{r}^{*}\right)=0$ e $\Pi_{\mathrm{f} 2}\left(\mathrm{r}^{* *}\right)=0$.

Braga (1998) demonstra que, sob as hipóteses até aqui assumidas, $\mathrm{r}^{*}<\mathrm{r}^{* *}$. Deste modo, se o banco fixar uma taxa de juros $r$, tal que $r \leq r^{*}$, os projetos das firmas 1 e 2 concorrerão ao empréstimo. Para o caso de $\mathrm{r}^{*}<\mathrm{r}<\mathrm{r}^{* *}$, apenas a firma 2 estará disposta a realizar o empréstimo, ou seja, a firma de maior risco. Se a instituição

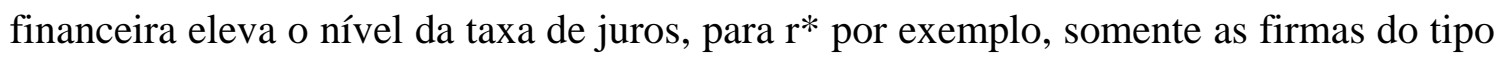
2 (as de maior risco) permanecerão no mercado, caracterizando um exemplo de seleção adversa no mercado de crédito.

Em suma, o modelo de Stiglitz \& Weiss (1981) mostra que existe uma taxa de juros que ao maximizar o lucro esperado da instituição financeira, pode estar abaixo da taxa que equilibra o mercado de crédito. Assim sendo, haverá um excesso de demanda por crédito, pois tanto as firmas do tipo 1, como as firmas do tipo 2, têm preferência por taxas de juros mais baixas. Logo, tem-se uma situação de equilíbrio com racionamento.

Ocorrerá o problema de seleção adversa nesse modelo quando há empreendimentos de alto risco que, ao se tornarem bem sucedidos, proporcionam maiores retornos que empreendimentos de baixo risco, o que propicia o pagamento de taxas de juros mais elevadas. Braga (1998), no entanto, argumenta que essa não é uma situação razoável quando se trabalha com projetos homogêneos, ou seja, é mais razoável supor que o banco se depara com diferentes categorias de empreendimentos como, por exemplo, diferentes culturas do setor agrícola. Nesta situação, o banco evitaria o problema de seleção adversa concentrando-se em grupos homogêneos ou, ainda, estipular ex-ante penalidades para o caso de inadimplência.

Uma possibilidade existente no modelo em questão é a ocorrência de assimetria de informação ex-post (após a formalização do contrato de empréstimo), que ocorrem em função de determinadas ações do devedor que não são observadas pelo credor. Quando a informação assimétrica ocorre ex-post, abre-se a possibilidade de ocorrência do risco moral.

São três os fatores citados por Braga (1998) que incentivam ações que podem resultar em problemas de risco moral, a saber: 
- Quando o custo de inadimplência é menor que o custo de se quitar a dívida

- Quando, numa situação de inadimplência, a possibilidade de renegociação que beneficie o devedor é mais vantajosa sob a ótica do credor

- Quando o esforço do devedor na condução do empreendimento financiado não é observado pelo credor

Pode-se observar que se na possibilidade de ocorrer seleção adversa, no modelo de Stiglitz \& Weiss (1981), o racionamento é a solução mais provável; para o caso de risco moral o banco passa a ter maiores custos, pois torna-se necessário o monitoramento das ações do devedor.

Finalmente, a conclusão de Stiglitz \& Weiss (1981) é de que os mercados de crédito podem não alocar, em função da assimetria de informação, os recursos disponíveis de forma eficiente. A obrigatoriedade de aplicação em determinados setores, tetos para taxas de juros, e intervenção do governo, são exemplos de tentativas de se equilibrar o mercado o mais próximo possível do seu nível de eficiência ótimo (Braga, 1998).

\subsubsection{O modelo de Driscoll (1991)}

Como já discutido nas seções anteriores, o mercado de crédito é caracterizado por uma situação em que há assimetria de informação entre os agentes que operam no mercado. Logo, dada a incerteza presente, dois são os problemas a serem considerados nesse mercado: seleção adversa e risco moral. $\mathrm{O}$ equilíbrio desse mercado pode ser uma situação em que é menor o retorno esperado pelos emprestadores.

O modelo de Driscoll (1991), discutido e ilustrado por Araújo (1996), pode ser exposto através de um gráfico de quatro quadrantes, sendo que no quadrante I tem-se a curva de demanda por empréstimos (inversamente proporcional à taxa de juros). $\mathrm{O}$ quadrante II expressa uma relação entre o retorno esperado dos empréstimos e taxa de juros. No quadrante III está a oferta de crédito relacionada positivamente com o retorno esperado do empréstimo. Finalmente, no quarto quadrante, tem-se uma linha de $45^{\circ}$ que 
permite relacionar os recursos emprestados com o quadrante I (Araújo, 1996). A figura 9 ilustra o modelo em questão.

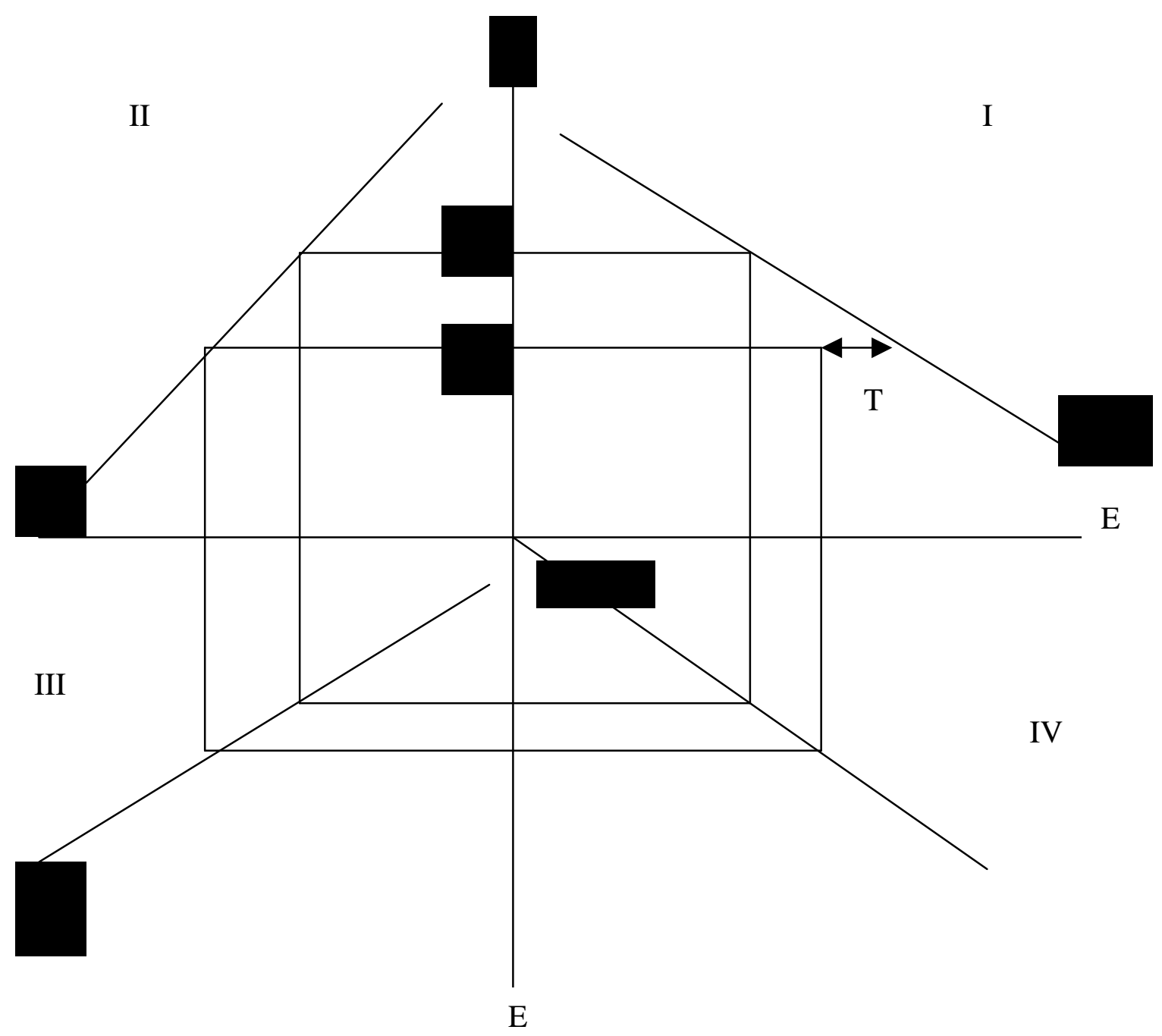

Figura 9 - Equilíbrio com Racionamento no Mercado de Crédito segundo o Modelo de Driscoll (1991).

Fonte: Araújo (1996)

Na figura 9 temos que $\mathrm{R}$ é o retorno esperado dos empréstimos, i é a taxa de juros, E os recursos emprestados. Também pode-se notar, na mesma figura, que o mercado encontra seu equilíbrio à taxa i', porém é à taxa $i^{*}$ que o mercado maximiza o 
valor esperado do retorno do emprestador, logo, em situação de equilíbrio, o mercado tem racionamento.

Araújo (1996) argumenta que as recomendações políticas para superar a ineficiência social provocada pelo racionamento no mercado de crédito ocorrem na direção de se aumentar a oferta de crédito, no entanto, deve-se sugerir também uma alocação mais eficiente da oferta existente. Alocar mais eficientemente a oferta existente significa reduzir a assimetria de informação, entre ofertantes e demandantes, via um sistema mais eficiente de classificação e seleção de risco dos empréstimos demandados.

\subsubsection{O modelo de Jaffee \& Russell (1976)}

O modelo desenvolvido por Jaffee \& Russell (1976) enfatiza o racionamento de crédito como a melhor maneira de diminuir a inadimplência, sendo que a política de racionamento dependeria da proporção entre tomadores honestos e desonestos.

Os autores assumem, no modelo, situações extremas: há no mercado tomadores honestos e desonestos. Os tomadores honestos são aqueles que fazem apenas um contrato de empréstimo e realmente honram seus compromissos. Já os desonestos, ao contrário, praticaram o default sempre que seus custos forem inferiores ao valor do empréstimo. No lado dos emprestadores, por sua vez, não haverá condições de se diferenciar os tomadores honestos e desonestos, o que caracteriza a presença de assimetria de informação.

São ainda hipóteses do modelo em questão: modelo de consumo em dois períodos, grande número de indivíduos, cada indivíduo tem função utilidade $\mathrm{U}(\mathrm{C} 1, \mathrm{C} 2)$ que é considerada quase-côncava e, finalmente cada indivíduo tem renda (Y1, Y2) para cada período.

A curva de demanda para empréstimos individuais é determinada pela solução do seguinte problema:

$$
\begin{aligned}
& \text { Maximizar } U\left(C_{1}, C_{2}\right) \text { em relação a } C_{1} \text { e } C_{2} \\
& \text { Sujeito a } C_{2}=Y_{2}-\left(C_{1}-Y_{1}\right) \cdot(R) \\
& \text { Sendo que } R=1+r, \quad r=\text { taxa de juros }
\end{aligned}
$$


A restrição orçamentária, sendo L o valor tomado no empréstimo no período 1 , de cada indivíduo honesto é dada por:

$$
\begin{gathered}
\mathrm{C}_{1}=\mathrm{L}+\mathrm{Y}_{1} \\
\mathrm{C}_{2}=\mathrm{Y}_{2}-\mathrm{L} \cdot \mathrm{R}
\end{gathered}
$$

Substituindo os valores da restrição orçamentária na função utilidade tem-se que:

$$
\text { Maximizar U[L } \left.+\mathrm{Y}_{1}, \mathrm{Y}_{2}-\mathrm{LR}\right]
$$

A condição de $1^{\circ}$ ordem para a solução do problema é:

$$
\frac{\partial U}{\partial L}=U_{1}-U_{2} \cdot R=0
$$

onde $\mathrm{U}_{\mathrm{i}}$ é a derivada parcial de $\mathrm{U}$ em relação ao i-ésimo argumento.

A função demanda dos empréstimos é formalizada da seguinte maneira:

$$
\mathrm{L}^{*}=\mathrm{L} *(\mathrm{R})
$$

e considera-se que a renda obtida em cada um dos períodos $\left(\mathrm{Y}_{1}\right.$ e $\left.\mathrm{Y}_{2}\right)$ não se altera.

Como condição de $1^{\circ}$ ordem tem-se que:

$$
\frac{\partial L^{*}}{\partial R} \leq 0
$$

A função demanda por empréstimos, e sua condição de $1^{\circ}$ ordem, mostra que quando a taxa de juros tende ao infinito o volume de empréstimos tenderá a zero, e quando a taxa de juros do empréstimo tender a zero a demanda será infinita.

Os tomadores desonestos por sua vez, definem Jaffee \& Russell (1976), são idênticos aos tomadores honestos, exceto quando o default dos empréstimos aumenta suas utilidades. Duas hipóteses adicionais são feitas para essa categoria de tomadores:

i) A demanda por empréstimos dos desonestos é exatamente igual à dos honestos. Se essa condição não fosse verificada, os emprestadores teriam como distinguir os diferentes tomadores. 
ii) Existe um custo de default expresso pela constante $\mathrm{Z}$ que é subtraída da renda no segundo período $\left(\mathrm{Y}_{2}\right)$, ou seja, o período em que o default ocorre.

No caso de não ocorrer o default, a restrição orçamentária dos indivíduos desonestos é exatamente a mesma dos indivíduos honestos. Caso contrário tem-se que:

$$
\begin{gathered}
\mathrm{C}_{1}=\mathrm{Y}_{1}+\mathrm{L}^{*} \\
\mathrm{C}_{2}=\mathrm{Y}_{2}-\mathrm{Z}
\end{gathered}
$$

Os tomadores desonestos escolherão o default na situação em que $\mathrm{Z}<\mathrm{L}^{*}$. R.

O trabalho de Jaffee \& Russell (1976) propõe que o comportamento do mercado de crédito, considerando-o competitivo e no qual os tomadores possuem mais informações sobre a possibilidade de default que os emprestadores, há duas possiblidades de equilíbrio:

i) Estado de equilíbrio com racionamento, que dependeria da proporção honestos/desonestos devido ao problema de seleção adversa.

ii) Alternativamente o mercado oscilaria em uma faixa instável onde emprestadores realizariam lucros de curto prazo e, em seguida, se retirariam do mercado.

Uma solução possível para evitar o racionamento de crédito, conforme Jaffee \& Russell (1976), é a intervenção do governo no sentido de estabelecer um poder de monopólio que, com a possibilidade de discriminação de taxa de juros em relação aos tomadores, garantiria um equilíbrio de mercado competitivo sem racionamento.

\subsubsection{O modelo de Hoff \& Stiglitz (1993)}

Hoff \& Stiglitz (1993) procuram definir um modelo de competição imperfeita para os mercados de crédito rural em países classificados como em desenvolvimento. Os autores assumem que a economia rural possui dois tipos de agentes: grandes e pequenos proprietários, e ambos os tipos com preferências idênticas.

Para a criação de um modelo básico do mercado de crédito, Hoff \& Stiglitz (1993) estabelecem três hipóteses básicas: 
(1) Acordos de pagamento dos empréstimos podem ser feitos somente entre bancos e proprietários de terra, que podem oferecer a terra como garantia, ou, entre emprestadores e seus clientes.

(2) Prestamistas têm informações para assegurar que o tomador de empréstimo individual realiza empréstimos de apenas uma fonte em determinado período.

(3) A única competição no setor de crédito informal é a competição de entrada no mercado, ou seja, não existe competição de preço.

Assume-se que os grandes proprietários possuem uma dotação de capital físico $(\mathrm{K})$, como terra, e trabalho. O capital é alocado entre investimentos na terra $(\mathrm{R})$ e empréstimos. O produto depende da terra, trabalho e investimento, mas como terra e trabalho são considerados constantes, a função de produção pode ser escrita como $F(R)$ com retornos decrescentes em $\mathrm{R}$.

Em relação aos pequenos proprietários, considerando-se a hipótese básica (1), estes podem tomar empréstimos de um único agente somente se esse agente puder fazer cumprir o acordo de pagamento do débito.

Considera-se, ainda, que não há custos marginais de estocagem e comercialização, o que implica que os prestamistas se defrontam com preços de competição perfeita; logo, o equilíbrio Bertrand/Nash é preço $(p)=0$ (Hoff \& Stiglitz, 1993).

Nesse mercado existem dois tipos de prestatários: (1) os bons, que honram seus compromissos; (2) os maus, que não honram seus compromissos, pois não conseguem produzir o suficiente para pagar o empréstimo. Há $\mathrm{N}$ prestamistas e Z bons prestatários, e a probabilidade de default destes é zero. Assim, os N prestamistas dividem o mercado simetricamente, cada um obtendo uma parcela $\mathrm{Z} / \mathrm{N}$ do mercado. $\mathrm{O}$ modelo é examinado pelo ajustamento dinâmico de curto prazo.

A quantidade emprestada pelo tomador de empréstimo é função da taxa de juros, como ilustra a expressão (1):

$$
\mathrm{Z}=\mathrm{Z}(\mathrm{i}) \quad \mathrm{Z}^{\prime}<0
$$


A expressão (1) implica que altas taxas de juros fazem com que os pequenos proprietários de terra tenham menos incentivos a realizar empréstimos.

Dada a hipótese básica (2), do modelo de Hoff \& Stiglitz (1993), o total emprestado por cada prestamista é L, onde:

$$
\mathrm{L}=\mathrm{Z}(\mathrm{i}) \cdot(\mathrm{Z} / \mathrm{N})=\mathrm{Z}(\mathrm{i}) \cdot \mathrm{m}
$$

sendo m o número de tomadores por prestamistas

A equação (3) define a taxa de juros como função do total emprestado e do número total de prestamistas:

$$
\mathrm{i}=\mathrm{i}(\mathrm{L}, \mathrm{N})
$$

sendo ainda:

$$
\{\partial \mathrm{LN}(\mathrm{i}) / \partial \mathrm{LN}(\mathrm{L})\}=\{\partial \mathrm{LN}(\mathrm{i}) / \partial \mathrm{LN}(\mathrm{N})\}=-\eta<0
$$

onde,

$$
\eta \equiv-[\partial \mathrm{LN} \mathrm{Z}(\mathrm{i}) / \partial \mathrm{LN}(\mathrm{i})]^{-1}
$$

A variável $\eta$ é definida como o inverso da elasticidade da curva de demanda de cada pequeno proprietário de terra, e será igual às alterações de preços geradas por aumentos na oferta de empréstimos de cada prestamista, ou da entrada de novos prestamistas no mercado. Esse resultado é a formalização da hipótese básica (3) (Hoff \& Stiglitz, 1993).

Assumindo que C representa os custos não pecuniários, Hoff \& Stiglitz (1993) definem que:

$$
\mathrm{C}=\mathrm{C}(\mathrm{L}, \mathrm{N})
$$

O exame e cumprimento de empréstimos levam a custos crescentes, logo:

$$
\mathrm{C}_{\mathrm{L}}=(\partial \mathrm{C} / \partial \mathrm{L})>0 \text { e } \mathrm{C}_{\mathrm{LN}}>0
$$


O problema de maximização do prestamista passa a ser, portanto:

$$
\operatorname{Max}\{F(K-\delta-L+G)-C(L, N)+i(L, N) . L-r . G
$$

sendo $\mathrm{G}=$ total emprestado por bancos estatais ou privados aos grandes proprietários de terra, e $\mathrm{r}=$ taxa de juros cobrada no empréstimo.

A condição de primeira ordem do processo de maximização é dada por:

$$
F^{\prime}=i[1-\eta]-C_{L}
$$

A expressão (8) mostra que os prestamistas comparam os retornos obtidos em suas terras com os retornos obtidos dos empréstimos. Para emprestar mais, ele deve reduzir a taxa de juros $r$.

O equilíbrio de livre entrada no mercado ocorrerá no ponto de tangência entre a curva de demanda por empréstimos, e curva de custo médio. A condição de equilíbrio é expressa por:

$$
\mathrm{Cme}=\mathrm{i} \text { e, }(\partial \mathrm{Cme} / \partial \mathrm{L})=(\partial \mathrm{i} / \partial \mathrm{L})
$$

A partir da expressão (3), podemos concluir que a elasticidade da curva de custo médio é igual à elasticidade da curva de demanda, ou seja:

\section{- $(\partial \mathrm{LnCMe} / \partial \mathrm{LnL})=\eta$}

Se um aumento inicial em $\mathrm{N}$ deixa a elasticidade da curva de custo médio inalterada, a taxa de juros inicial permanecerá no mesmo ponto de equilíbrio. No caso de um aumento inicial de $\mathrm{N}$ aumentar $\eta$, a curva de demanda será tangente à nova curva de custo médio em um ponto em que a nova taxa de juros será inferior à taxa de juros inicial, e os prestamistas perceberão que poderão aumentar seus lucros diminuindo as taxas de juros. E, finalmente se, dado um aumento em $\mathrm{N}$, ocorrer uma redução de $\eta$, a 
curva de demanda será tangente à nova curva de custo médio em um ponto onde a nova taxa de juros será superior à taxa de juros inicial.

Hoff \& Stiglitz (1993) definem como resultado perverso do modelo a situação em que um aumento do crédito formal $(\mathrm{G})$, provoca uma redução do crédito informal e maiores taxas de juros no mercado. Isso ocorreria no caso de custos crescentes de monitoramento na dimensão dos empréstimos, entrada de externalidades no mercado via prestamistas, ou a entrada de prestamistas ser grande devido a uma grande elasticidade para a demanda de crédito para cada tomador de empréstimo.

O mercado rural, segundo Hoff \& Stiglitz (1993), é segmentado devido à ausência de pequenos custos e confiança em uma estrutura legal, e um sistema de transmissão de informações. A conseqüência da fragmentação do mercado é a grande diferença entre o preço do capital para diferentes tomadores de empréstimo, sendo esse o argumento utilizado em grande escala para justificar os subsídios do governo para a expansão do crédito formal em áreas rurais. No entanto, a provisão de fundos para o setor rural pode ser ineficiente, pois parte substancial do subsídio implicado nos empréstimos pode ser dissipada durante a entrada excessiva de prestamistas no mercado. 


\section{ENTRAVES E NOVOS INSTRUMENTOS PARA UM NOVO MODELO DE FINANCIAMENTO RURAL}

\subsection{Considerações gerais}

A falta de recursos do sistema tradicional de crédito rural é uma forte evidência de que este modelo chegou ao seu esgotamento. Além do mais, existe uma legislação muito pouco adequada uma vez que, através da burocracia, dificulta a concessão de crédito. Em relação aos bancos privados o maior entrave reside na falta de credibilidade dos tomadores, que estão fortemente endividados.

No contexto macroeconômico a situação geral do financiamento da agricultura não é menos cômoda, uma vez que as altas taxas de juros praticadas na economia brasileira estão em níveis considerados elevados, e sem perspectivas de redução considerável em um cenário de curto-médio prazo, o que eleva sobremaneira os custos da agricultura, na tomada de financiamento no mercado.

Gasques et al. (2000) acrescentam que a falta de capilaridade do sistema, que concentra as linhas de crédito quase que totalmente no sistema bancário, e a elevada concentração do risco da operação no produtor (não há um sistema de proteção ou diluição do risco por todo o sistema) também são grandes entraves para um novo sistema de financiamento.

Até o momento, apesar de uma série de propostas discutidas no âmbito acadêmico ou no Congresso Nacional, não surgiu algo que possamos considerar como um novo sistema de financiamento da atividade agrícola. A CPR (Cédula do Produto Rural) tem-se mostrado um eficiente instrumento de captação de recursos privados para a produção, porém ainda está restrita a poucos produtos e em volume muito inferior ao necessário para suprir o volume de recursos outrora advindos do governo federal. A 
priori são duas as limitações associadas apenas ao uso de CPR como instrumento de captação de recursos: i) uma boa parte da lavoura brasileira é formada por produtos pouco contemplados no mercado financeiro (arroz, feijão, mandioca entre outros) de forma que as ações de mercado não substituem por completo as ações governamentais; ii) o mercado de futuros no Brasil, devido à falta de um número suficiente de especuladores, possui pouca liquidez o que se torna um obstáculo para o seu desenvolvimento.

Embora não se tenha definido um novo sistema de crédito rural, seja qual for o sistema a ser determinado nos próximos anos, não poderá se furtar a três características consideradas essenciais por Araújo et al. (2000): criação de um fundo fiscal que capte recursos externos; maior participação de títulos mercantis relacionados aos mercados físicos e de futuros e a ampliação das linhas de recursos externos.

\subsection{A CPR como um instrumento alternativo de captação de recursos}

Simultaneamente à drástica redução de crédito destinado ao financiamento da agricultura surgiu a CPR (Cédula do Produto Rural) como uma alternativa de captação de recursos financeiros para a produção.

Gonzalez (1999) mostra que o cenário vivenciado pela agricultura nos anos 90 foi caracterizado por crescimento da produtividade com área relativamente constante e preços, na maior parte da década, desfavoráveis. A escassez de crédito forçou os produtores a buscar alternativas que substituíssem o financiamento público das safras e da comercialização.

As primeiras experiências de compra e venda antecipada da produção ocorreram com a soja, na região do cerrado, em meados dos anos 80. Essas operações eram realizadas através de contratos com preço a fixar e o produtor comprometia um volume maior de soja contra o adiantamento do recurso para custeio da safra (Pimentel, 2000).

Em 1993 foi criado o CM-G (Certificado de Mercadoria com Emissão Garantida), que era um título mercantil de contrato de compra e venda nas modalidades entrega física futura garantida (CMFG) e entrega física disponível garantida (CMDG). A 
negociação desse título ocorria apenas em bolsas de mercadorias, sendo que o produtor rural poderia utilizá-lo como forma de captação de recursos para o financiamento de sua produção (Gonzalez, 1999). Paralelamente à criação do CM-G o Banco do Brasil, através da lei 8.929 de 22/08/94, iniciou de forma experimental as operações com a CPR, cujas características são de um título financeiro e de contrato a termo. Para evitar a duplicidade de venda do produto, os negócios envolvendo a CPR podem ser registrados na CETIP (Central de Custódia e Liquidação Financeira de Títulos).

A CPR, na forma em que foi criada pelo Banco do Brasil, é um título cambial que pode ser emitido por produtores rurais (pessoa física ou jurídica) e suas cooperativas de produção com as seguintes características:

a) $\mathrm{O}$ emitente vende a termo sua produção agropecuária, recebe o valor da venda à vista (ou em máquinas/insumos) e se compromete a entregar o produto negociado na quantidade, qualidade, local e data estipulados;

b) Vale o produto/quantidade nela declarado;

c) Transferível a outro comprador, por endosso;

d) Negociável no mercado secundário, como ativo financeiro, enquanto vincendo.

Quando foi instituído a CPR, o mecanismo de captação de recursos era o mais simples possível: o produtor emitia uma CPR, recebia imediatamente uma quantia em dinheiro correspondente a uma quantidade de produto e se comprometia a entrega-la no vencimento da operação. Tal operação nada mais é do que uma venda antecipada da produção.

No caso de liquidação física o aval da CPR é importante para a redução dos riscos da operação, pois o aval do BB oferece total garantia ao comprador de que ele receberá o seu produto. O BB compromete-se a honrar a entrega do produto negociado até dez dias após o vencimento da cédula, caso o vendedor não o faça. Portanto, a CPR avalizada pelo Banco do Brasil torna- se um negócio sem risco para o comprador. 
Originalmente, a CPR, enquanto um contrato, a termo, tinha liquidação por entrega física apenas. Seguindo a argumentação de Gonzalez \& Marques (2000), a CPR física tinha como principal entrave a necessidade de se conciliar um comprador que esteja demandando um produto com as mesmas especificações que o produto ofertado, característica essa que, claramente, limitava a expansão do mercado de CPR e, principalmente, o envolvimento do mercado financeiro.

Através da Medida Provisória 2.017 de 19/01/2000, passou a ser permitida a liquidação financeira da CPR. A única diferença entre as CPR's de liquidação física e financeira está na forma como é feita a liquidação. A CPR de liquidação financeira não exige a entrega física do produto, pois o resgate do título é uma operação de recompra da CPR pelo produtor com base em preços, ou indicadores, anteriormente definidos.

A grande vantagem de se permitir a liquidação financeira de uma CPR está no fato de abrir o mercado para qualquer financiador, pois não mais é necessário o recebimento do produto, mas o valor em dinheiro equivalente à quantidade do produto. Schouchana (2000) argumenta que para isso, no momento da emissão do título, deve constar qual o preço que será utilizado para converter mercadoria em valor no momento em que vence o título, e sugere que sejam adotados preços da BM\&F devido à transparência e conhecimento por parte do mercado.

Gonzalez \& Marques (2000) apresentam inúmeras vantagens da possibilidade de liquidação financeira da CPR, citadas a seguir:

a)Criação de maior atratividade para os investidores

b)Difusão entre os produtores do hábito de negociar em futuros

c) Não necessidade de classificação oficial do produto

d)Aumento do número de compradores, o que aumenta consideravelmente a liquidez dos títulos.

e) Redução do diferencial entre os preços dos momentos de contratação e de liquidação

f) Redução de custos operacionais

g)É um mecanismo adicional para captação de recursos para a atividade agrícola 
Gonzalez (1999) afirma que, sob a ótica conceitual, a CPR pode beneficiar qualquer produto agropecuário in natura, beneficiados ou industrializados. Os agentes que participam das operações de compra e venda de uma CPR são: produtores, beneficiadores e tradings. Segundo este autor, a CPR é uma modalidade de contrato a termo com entrega diferida, preço fixado quando da concretização do negócio e quitação financeira nesse momento e, pelo fato de ser transacionado no mercado a termo, se caracteriza como instrumento de proteção contra risco e baixa de preços. Portanto, conclui Gonzalez (1999), a CPR é mais que um instrumento de financiamento é uma garantia de preço.

Schouchana (2000), no entanto, adverte para dois problemas em relação à CPR com liquidação financeira: o elevado custo de aval, uma vez que o risco da agricultura é alto, e as altas taxas de juros praticadas na economia brasileira, sendo que esta variável depende da política macroeconômica executada no país. A questão das taxas de juros será detalhadamente abordada em outra seção deste trabalho.

Outro ponto relevante que limita as operações com mercados futuros no Brasil é, segundo vários analistas do mercado, a falta de tomadores de risco. Por isso deve ser destacado o fato do governo brasileiro ter autorizado os não-residentes a operarem com o mercado de opções de produtos agrícolas da BM\&F (Schouchana, 2000). A possibilidade de comprar uma opção de venda permite, ao produtor rural, se proteger contra uma baixa no preço do produto.

Como são muitos elevados os custos de $\mathrm{aval}^{7}$ da CPR há, no mercado, muitas CPR's de gaveta (sem registro na CETIP) em poder de empresas, de acordo com Pimentel (2000), sem tradição no mercado e sem estrutura capaz de fiscalizar a liquidação dos compromissos de entrega. Estima-se que haja no mercado em torno de R\$ 4 bilhões em CPR de gaveta, entretanto, deve-se considerar que não há nenhum estudo formalizado a esse respeito que permita plena convicção nesse número. Por outro lado, é inegável o potencial apresentado pelo mercado de CPR. A própria evolução do

\footnotetext{
${ }^{7} \mathrm{O}$ emitente da BB CPR arca com a taxa de aval (que varia de 0,45\% e 0,65\% ao mês) aplicado sobre o valor do negócio, e com os custos de registro do título em cartório.
} 
mercado de CPR's registradas, mesmo com os custos de aval, não deixa nada a desejar, como mostra a figura 10.

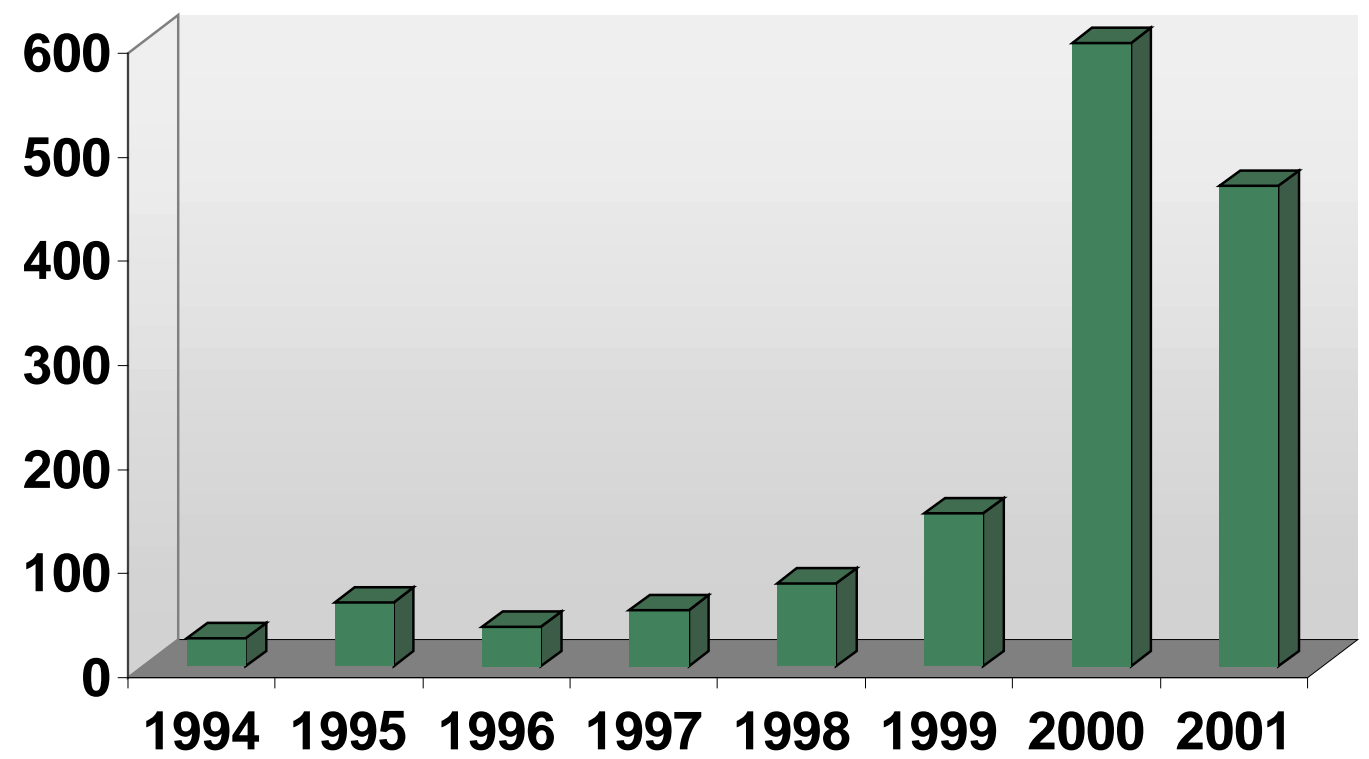

Figura 10 - Negócios com CPR, 1994 - 2001* (em milhões de R\$).

Fonte: Banco do Brasil

Nota: Os valores para o ano de 2001 foram computados até o mês de agosto

O crescimento dos negócios com CPR foi, no período considerado, de $1610 \%$ aproximadamente, sendo a maior parte com CPR de liquidação financeira. Café e boi gordo, em conjunto, representaram 56\% das operações. Uma das justificativas para um crescimento dessa envergadura é o fato da CPR permitir, além do financiamento da produção, a possibilidade de proteção dos preços. Gonzalez (1999) ainda atribui à CPR dois outros papéis: (1) fixar o nível de lucro para a parcela da produção comercializada (com receitas e custos fixados); (2) viabilizar o plantio/tratos culturais da lavoura pois afasta "do produtor o dimensionamento do custo econômico que lhe seria impingido caso esses tratos não fossem realizados" (Gonzalez, 1999, p. 148).

\subsection{O sistema de microcrédito}

Gasques et al. (2000) definem microcrédito como sendo "a provisão de um conjunto de serviços financeiros tais como depósitos, empréstimos, serviços de 
pagamento, transferência de dinheiro para a população mais pobre que não tem acesso aos bancos comerciais tradicionais". Via de regra, as instituições que prestam serviços de microcrédito são: bancos rurais, cooperativas e organizações não governamentais.

Segundo dados da FAO (2000), o número total de tomadores registrados em programas de microcrédito cresceu, entre 1998 e 1999, algo em torno de 50\%. Os objetivos gerais dos programas de microcrédito são:

- Financiar grupos de tomadores excluídos de instituições formais de crédito

- Incluir serviços não creditícios

- Estabelecer uma relação de grupos de empréstimo

As organizações não governamentais (ONGs) são responsáveis pela maioria dos programas de microcrédito pois, geralmente, são bem estabelecidas em comunidades locais e bom relacionamento com a comunidade. Muitas das ONGs recebem assistência internacional, ou ainda, ONGs internacionais operam no país através de agências locais (Gasques et al., 2000).

Os bancos comerciais, por sua vez, apenas recentemente começaram a operar com o microcrédito. Uma gama bem variada de estratégias é adotada pelos bancos a fim de atender clientes de baixa renda, geralmente classificados como clientes de alto risco. O banco comercial pode operar com o microcrédito de forma indireta ou direta. A forma indireta de se operar com o microcrédito consiste no fornecimento de recursos para empréstimo às ONGs, que são as intermediárias do empréstimo. Cabe, portanto, às ONGs, as funções de avaliação, monitoramento e recuperação do empréstimo.

A atuação direta de bancos comerciais nos programas de microcrédito ocorre quando os bancos criam um departamento especializado em microcrédito, procurando estimular uma variedade de serviços para os clientes de baixa renda.

Em diversas seções deste trabalho foi destacado que o mercado de crédito apresenta altos custos de transação e uma falha de mercado conhecida como assimetria de informação, fatores esses que alteram o equilíbrio do mercado. O sistema de microcrédito, a priori, consegue reduzir os efeitos dessas falhas de mercado tanto que tem sido bastante utilizado pelo Banco Mundial e pelos programas de financiamento rural da FAO (Food and Agriculture Organization). De acordo com dados da FAO, entre 
1998 e 1999 o volume de empréstimos via programas de microcrédito cresceu 50\%, atingindo 21 milhões de pessoas no mundo.

No Brasil são poucas as experiências com microcrédito, Gasques et al. (2000) relatam a experiência do Prorenda, que vem sendo desenvolvida nas comunidades rurais da Zona da Mata e do Agreste do Estado de Pernambuco. Nesse sistema, o crédito é concedido através de um fundo rotativo, e os reembolsos dos créditos concedidos são acumulados e reutilizados para outros créditos sucessivos. De qualquer forma, embora tenha resultados satisfatórios nas regiões onde é utilizado, o microcrédito nos parece mais adequado às regiões rurais menos desenvolvidas e para a agricultura familiar, sendo impossível adotar esse sistema como forma de financiamento da agricultura denominada comercial, ou seja, de produção em maior escala, voltada para o mercado interno e externo.

\subsection{A opção de financiamento via mercados informais}

Como já foi discutido exaustivamente na literatura sobre crédito rural no Brasil, e particularmente neste trabalho, o volume de crédito proveniente do governo é muito escasso, e o sistema criado a partir do SNCR de 1965 está praticamente inviabilizado. Portanto, além da busca por novas formas de financiamento de natureza essencialmente de mercado, o sistema informal de crédito rural é uma alternativa que não pode ser desprezada.

Ocorre financiamento informal da atividade agrícola quando a captação de recursos é feita fora do sistema financeiro ou da esfera governamental. Por se tratar de operações que pouco, ou nada, exigem como garantia de empréstimo, e por envolverem um contato muito próximo entre emprestador e tomador, o financiamento informal incorre em custos de transação relativamente reduzidos.

Araújo et al. (2000) ressaltam quatro operações de financiamento da agricultura via sistema informal: i) empréstimos em dinheiro obtidos de particulares ou firmas cuja atividade está relacionada ao setor agropecuário; ii) operações de escambo na base insumo/produto, serviço/produto, cooperativas/firmas e produtores, entre outros; iii) compras e vendas antecipadas da produção entre produtores, comerciantes ou empresas 
agroindustriais; iv) poupança e empréstimo realizados por grupos ou associações informais de agricultores.

Almeida (1994) realizou uma pesquisa com base em informações sobre 279 produtores rurais de dez regiões diferentes do Brasil. O objetivo da pesquisa era qualificar e, de acordo com a disponibilidade de dados, quantificar a importância dos mercados informais como instrumento de captação de recursos para o financiamento da atividade agrícola brasileira.

Os resultados obtidos por Almeida (1994) são relevantes para qualquer análise sobre crédito informal. $\mathrm{O}$ autor afirma que a intermediação financeira informal atua, no Brasil, como um "elo de ligação entre o capital próprio e os recursos obtidos nos mercados informais". A crescente participação dos mercados informais no crédito rural, durante a década de 90, mostra a importância do financiamento informal para a agricultura. Almeida (1994) estimou que 30\% dos empréstimos concedidos aos produtores selecionados eram, no ano de 1990, de natureza informal. Para a mesma amostra o autor concluiu que a proporção entre crédito informal e necessidades de capital foi, entre 1989/90, da ordem de 10,2\% na amostra como um todo, e de $34,5 \%$ no grupo de agricultores com menor renda.

Duas outras conclusões do trabalho de Almeida (1994) também merecem destaque: i) os agricultores de maior porte (agricultura em grande escala) demandam crédito intensamente, independente da origem dos recursos e, por isso, estão mais sujeitos ao endividamento; ii) os juros dos empréstimos informais possuem maior amplitude de variação que os observados nos empréstimos formais, sendo que em alguns casos a taxa real de juros nos empréstimos informais equivale a três vezes à praticada em operações de empréstimo formais, pois nela estão embutidos os custos de oportunidade dos recursos e o risco de inadimplência dos tomadores do empréstimo.

Finalmente, Almeida (1994) argumenta que a forte intervenção governamental, excessiva carga tributária, escassez de recursos financeiros e sistemas de fiscalização e controles deficientes são fatores adicionais que incentivam o crescimento do sistema informal de crédito. O autor defende a liberação das taxas de juros do crédito rural formal, de forma que haveria estímulo para a concorrência de empréstimo entre os 
bancos privados, pois poderiam negociar livremente com o agricultor. O benefício dessa medida seria o aumento do volume de recursos destinados ao crédito rural, e inibiria o “efeito substituição" definido por Sayad (1978), pois o produtor somente faria o empréstimo quando o retorno financeiro de seu projeto fosse equivalente, ou superior, ao custo financeiro do empréstimo. A simplificação dos procedimentos de empréstimos formais também é recomendável, na visão de Almeida (1994), pois o sistema informal, por ser intermediado por cooperativas, agroindústrias e comerciantes de insumosprodutos, consegue reduzir muito os custos de transação das operações de empréstimo.

A ressalva que Pessoa (1996) faz ao crédito cooperativo está na fragilidade das cooperativas nacionais, uma vez que não possuem uma situação financeira sólida e, em relação ao crédito rural, não estariam preparadas, pelo menos por enquanto, para atuarem em larga escala. 


\section{REFLEXÕES SOBRE UM NOVO MODELO DE FINANCIAMENTO RURAL}

\subsection{Considerações iniciais}

Ao longo dos últimos dez anos o sistema oficial de crédito rural mostrou sinais de esgotamento e, atualmente, caminha para uma nova situação que se caracteriza pela pouca participação do governo. O argumento central para a ausência, quase total, do governo nesse novo sistema de crédito seria a impossibilidade do governo prover recursos para a agricultura, ou qualquer outro setor da economia, sem afetar o equilíbrio fiscal, que é o atual pilar da estabilidade monetária alcançada em 1994.

O rumo que vem sendo tomado pelo sistema de crédito para a atividade agrícola, com cada vez menos intervenção governamental, é falho sob o enfoque prático de mercado e também sob o enfoque da teoria econômica. Conforme Stiglitz \& Weiss (1981) a variável taxa de juros não explica satisfatoriamente o comportamento do mercado de crédito, pois, se elevada pode atrair tomadores de alto risco de default para o mercado e diminuir o retorno esperado dos fornecedores de empréstimo.

No caso específico da agricultura, como mostram Hoff \& Stiglitz (1993), há muitos tomadores com alta probabilidade de default no mercado, porque a atividade agrícola não é capaz de produzir uma rentabilidade suficiente para o pagamento do empréstimo. Esse cenário é ainda mais desfavorável à agricultura na economia brasileira uma vez que, como abordado na seção 5.2, os juros reais ao longo dos últimos dez anos estiveram, em média, próximos de $15 \%$ ao ano. Em se tratando de atividade agrícola, certamente é impossível buscar financiamento no mercado financeiro e, dadas as condições macroeconômicas atuais do Brasil, não há sinais de alteração desse cenário a curto-médio prazos. 
No sistema de crédito norte-americano até meados dos anos 80 , dois terços do volume de recursos destinados à atividade rural eram provenientes da Farm Service Agency (FSA), exclusivamente governamental, e da Farm Credit System (FCS) cujos recursos eram privados, porém com a ajuda do governo (Gasques et al., 2000).

Oliveira (1995) afirma que $17 \%$ do crédito rural nos Estados Unidos, atualmente, é originário de fontes públicas, como as seguintes agências: Commodity Credit Corporation (CCC), Farmers Home Administration (FmHA) e Small Business Administration (SBA). Os recursos destinados por essas agências são oriundos do Tesouro americano e aprovados pelo Congresso como venda de títulos, ações e debêntures, cuja liquidez é garantida pelo governo, e as taxas de juros cobradas nos financiamentos são, por vezes, subsidiadas embora mantidas sempre acima dos custos de captação dos títulos do Tesouro norte-americano (Oliveira, 1995).

A atuação do governo como principal fomentador de recursos, às custas do desequilíbrio fiscal e da falta de equidade na distribuição do crédito, está corretamente descartada de um novo sistema de crédito rural. No entanto, o governo é um agente importante tanto na fase de transição do sistema tradicional, como também em um novo sistema baseado em recursos do mercado. O governo, enquanto agente regulador e não mais como principal gerador de recursos, tem basicamente três funções conforme Hoff \& Stiglitz (1993):

1. Reduzir custos de transação do sistema

2. Definir uma estrutura legal eficiente e capaz de reduzir os incentivos para um eventual default

3. Criação de um sistema de transmissão de informação para a redução da assimetria de informação

\subsection{As taxas de juros como principal entrave macroeconômico}

Segundo o Relatório do Banco Mundial de 1989, a década de 80 foi, depois da época da Grande Depressão, o período em que as taxas de juros estiveram mais altas em âmbito mundial. A principal causa do aumento dos juros teria sido, segundo o relatório, a contenção monetária que derrubou a inflação e elevou as taxas de juros nominais de 
vários países. A segunda justificativa seria a diminuição da poupança mundial, no período, que se reduziu em dois pontos, e estacionou na ordem de $11 \%$ em 1987, ocasionada em grande parte pelo aumento do déficit fiscal dos Estados Unidos, e da redução da poupança privada de outros países.

Após a bem sucedida experiência neo-zeolandeza em adotar o sistema de metas inflacionárias, há uma tendência dos governos, atualmente, em optarem por promover o crescimento econômico via uma política monetária mais frouxa com uma política fiscal mais austera, e atrelando a expansão monetária com as metas de inflação futuras. A característica deste regime monetário, conforme Mendonça (2001), é o anúncio oficial dos limites de flutuação para um horizonte de curto a médio prazos, sendo a taxa de juros uma variável relevante para o governo manter a economia dentro dos limites prédeterminados de inflação.

Sachs (1995) mostra que as crises internacionais dos anos 70 não favoreceram a diminuição das taxas de juros o que implicou em maiores dificuldades, para os países em desenvolvimento, de crescimento econômico, pois reduziria custos de novos investimentos, reduziria a relação dívida/exportação e, portanto, permitiria a diminuição de transferências líquidas de riqueza interna para o exterior. A figura 11 mostra a evolução da taxa Over Selic (que é a taxa de juros básica da economia) em valores reais de janeiro de 1989 a dezembro de 1999, sendo que os valores nominais foram deflacionados pelos seguintes índices de preços: INPC, IGP-M, IPC-M, IPA-M.

Foram utilizados vários deflatores para comparação de possíveis diferenças quanto aos níveis dos juros reais. Porém, como mostra figura 11, as diferenças não são significantes. As séries das taxas de juros reais são identificadas, na figura 11, pelo nome do deflator utilizado para o cálculo da taxa.

Independente do índice de preços utilizado percebe-se facilmente que as taxas de juros reais para a economia brasileira estão muito altas há mais de uma década, ficando em média ficam em torno de $15 \%$ ao ano. Algumas distorções ocorrem nos anos em que foram implementados planos econômicos, pois há, por um curto período de tempo, redução dos juros nominais mais acentuada que a redução da taxa de inflação, de 
forma que é necessário um tempo maior de ajuste dos preços a fim de que se tenha uma taxa de juros real correspondente com o novo patamar dos preços da economia.

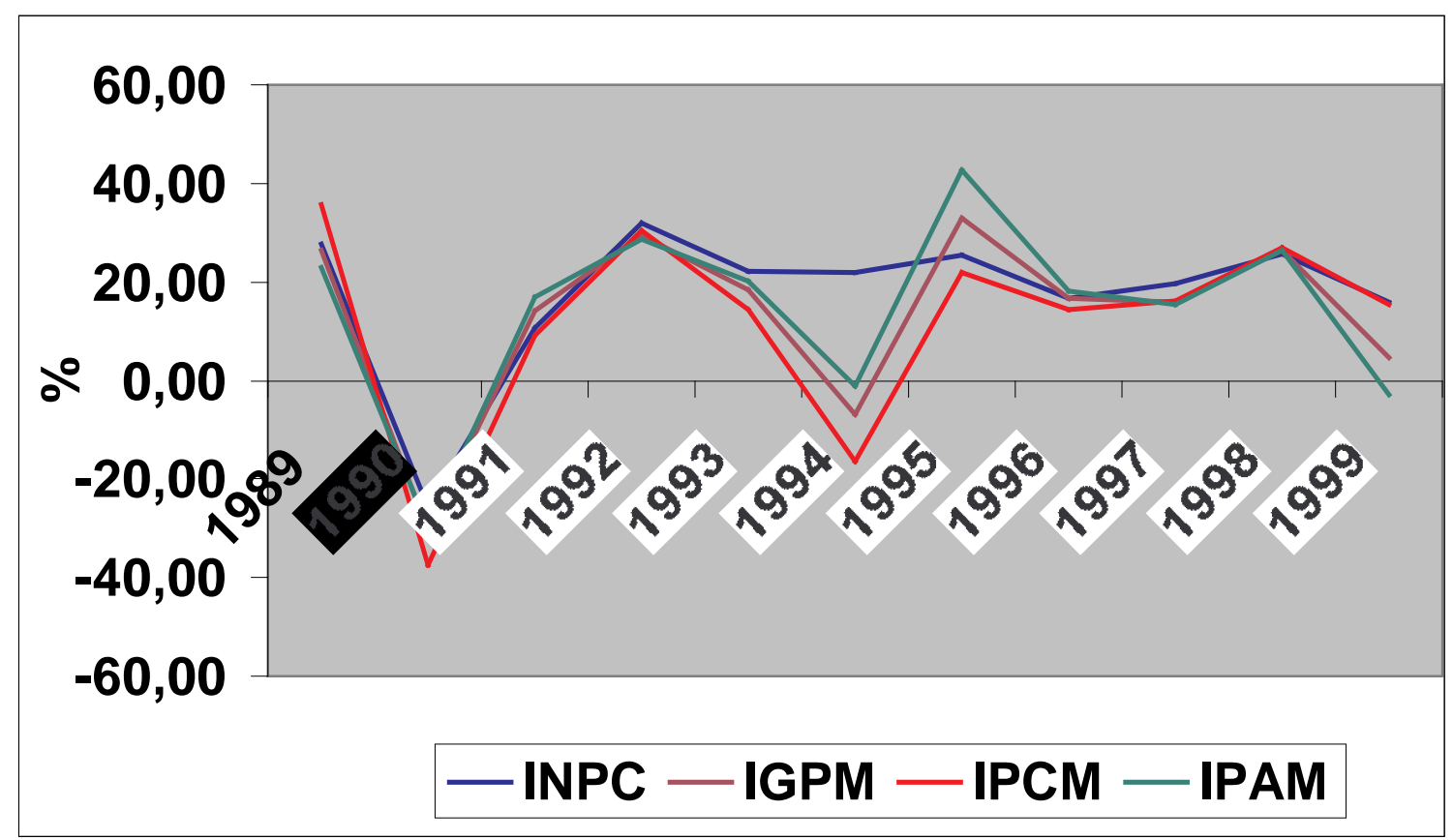

Figura 11 - Evolução Mensal da Taxa Over Selic em Valores Reais Deflacionada por Diversos Índices de Preços (1989 - 1999).

Fonte: BACEN, IBGE e dados do autor

Taxas de juros elevadas, em geral, favorecem formas financeiras como poupança em detrimentos de outras atividades não-financeiras. Por outro lado, taxas de juros negativas, como ocorreu em certos momentos da década de 70 , desestimulam a posse de ativos financeiros. Fry (1982), citando Mackinnon \& Shaw (1973), argumenta que taxas de juros mantidas, de forma artificial, em níveis muito baixos, exercem uma "repressão financeira" sobre o sistema financeiro, o que acaba provocando uma redução dos ativos financeiros em termos reais (e com maior intensidade em períodos de inflação elevada). A conclusão de Mackinnon \& Shaw (1973), exposta por Fry (1982), é que se a expansão da atividade financeira é um fator dos mais relevantes para o desenvolvimento da economia; os juros extremamente baixos podem representar um grave obstáculo ao crescimento econômico. 


\subsubsection{O plano real, a âncora monetária e a agricultura brasileira}

Conforme Homem de Melo (1998) o sucesso da estabilidade monetária, após a eficiente combinação de indexação (URV) e desindexação (introdução do Real), ficou muito dependente das âncoras monetária e cambial, ou seja, elevadas taxas de juros no mercado financeiro e valorização da taxa de câmbio em relação ao dólar.

Toledo (1999) explicita os rumos da política monetária praticada a partir de 1994 em três níveis, sendo eles:

a) Direção requerida: taxas de juros acima dos padrões internacionais, tanto em termos reais, como relativamente à desvalorização cambial.

b) Suficiência de intensidade: considerada excessiva, provocando rápido aumento de reservas internacionais, e com média na taxa de juros de $20 \%$ aa (entre Julho/94 a Setembro/98). A consequiência principal foi a elevação substancial do déficit público e da dívida pública.

c) Realização do objetivo: embora tenha provocado o aumento das reservas internacionais, é considerada insatisfatória pelo fato de ter provocado efeitos nocivos sobre a política fiscal.

Analisando os efeitos da valorização cambial, processo esse iniciado em meados de 1994, Homem de Melo (1998) constatou que a apreciação cambial provocou expressiva redução dos preços agrícolas reais no Brasil. A produção agrícola, por sua vez, não sofreu diminuição. Por outro lado também não apresentou um crescimento mais que modesto em volumes totais, e houve redução no volume per capita (Homem de Melo, 2001).

Santiago \& Silva (1999) argumentam que as alterações nas regras e condições de operação do crédito rural, após diversos planos de estabilização econômica, associados ao fraco desempenho da renda agrícola, contribuíram, em grande parte, para o endividamento e inadimplência do setor agropecuário. Esse quadro aumenta sobremaneira as dificuldades dos agricultores em obter financiamentos formais, de forma que as operações realizadas fora do sistema financeiro e do controle do governo 
(chamadas de crédito informal) passam a ganhar mais importância, especialmente para os agricultores de pequeno porte.

Em um estudo mais recente, Santiago (2000) alerta para o fato de que até o começo da década de 80 as taxas de juros eram subsidiadas, situação que se alterou com a liberação dos mercados financeiros na década seguinte. Segundo a autora, existem evidências de que o crescimento do endividamento dos produtores rurais se acentuou após o Plano Real, não só pela queda dos preços agrícolas, como, também, pelo impasse da renegociação da dívida, à época, bem como pelo crescimento da taxa de juros do crédito rural, que influencia o índice de correção dos empréstimos.

Santiago (2000) ainda mostra que o processo de concessão de crédito, até os anos 80, não obedecia a critérios econômicos, restringindo-se a critérios mais burocráticos. O resultado foi o beneficiamento de alguns grupos de produtores, os mesmos grupos que posteriormente apresentaram problemas de endividamento e pressionaram o governo para renegociar a dívida agrícola, o que culminou com o processo de securitização em 1995.

\subsection{O papel do governo em um novo sistema de crédito}

Conforme ilustrado na Tabela 4 (seção 2.1), os recursos do Tesouro Nacional sofreram uma drástica redução ao longo das últimas décadas. Em 1991 esses recursos representavam $24,18 \%$ do valor concedido ao financiamento da atividade rural. Entretanto, em meados do ano 2000 esse valor estava próximo de 0,02\%. As novas fontes de recursos, como Fundo de Amparo ao Trabalhador (FAT) e a Poupança Rural, contam com a presença do governo federal. Porém, a redução do valor total de recursos do Sistema Nacional de Crédito Rural confirma a saída, ainda que gradual, do governo federal no sistema de crédito à agricultura, o que pode não ser a melhor solução para o problema de financiamento da agricultura brasileira no atual momento.

O mercado de crédito, devido à falhas de mercado, como assimetria de informação e externalidades, não tem seu equilíbrio atingido nos padrões dos mercados competitivos (baseados na premissa de que a informação é perfeita). Os mercados competitivos, os mercados financeiros, por exemplo, são ineficientes na oferta de bens 
públicos, pois é muito difícil se apropriar dos retornos destes bens. O bem público que causa falhas no mercado financeiro é a informação.

A informação é uma falha de mercado que restringe o volume de recursos destinados ao crédito: quando há muitos tomadores de empréstimos com alta probabilidade de default, os bancos tendem a emprestar menos recursos do que estariam realmente dispostos, uma vez que a informação não é perfeita e os bancos, a priori, não conseguem diferenciar os tomadores de empréstimo em função das suas capacidades de pagamento. O equilíbrio do mercado de crédito, por conseguinte, ocorre com excesso de demanda por empréstimos.

Stiglitz (1993) ressalta que o mercado de crédito apresenta falhas que o impedem de ter um equilíbrio de mercados competitivos, a saber:

1. Informação é um bem público

2. Assimetria de informação

3. Competição imperfeita

Os mercados competitivos não são capazes de gerar oferta suficiente de bens públicos e informação, conforme Stiglitz (1993), é um bem essencialmente público, uma vez que é um bem muito custoso de se obter e difícil de conseguir retorno com sua posse. Além disso, como a informação não é simétrica entre os agentes, existe a possibilidade de ocorrência de seleção adversa e moral hazard, o que implica em maiores custos de transação entre os agentes. Portanto, o mercado de crédito é imperfeito, com informação imperfeita e é afetado pelas ações dos agentes econômicos, o que faz de seu equilíbrio, se não houver qualquer interferência, Pareto ineficiente.

Stiglitz (1993) ainda ressalta outros fatores que afetam o equilíbrio no mercado de crédito: monitoramento de instituições é um bem público, monitoramento de solvências e, finalmente, conseqüências de monitoramento inadequado. Esses três fatores são resultado da característica de bem público da informação. O monitoramento de instituições financeiras (no que diz respeito à possibilidade de solvência) é relevante porque afeta os riscos e retornos dos investimentos, porém não há incentivos para os agentes do mercado realizarem essa atividade, pois o monitoramento de solvências ainda possui as características de não-rivalidade e não-exclusividade. Essas características 
fazem com que seja falho o serviço de monitoramento e, conseqüentemente, provocam um comportamento mais arriscado das instituições financeiras em seus empréstimos e uma alocação ineficiente de recursos entre os agentes de mercado.

A partir do trabalho de Stiglitz (1993) percebe-se, claramente, que consiste um erro teórico, e prático, o governo permitir que o mercado de crédito, per se, atue livremente, até atingir seu equilíbrio que, como exposto na seção 3.3.1, será caracterizado por excesso de demanda por empréstimos, ou seja, Pareto ineficiente.

É importante ressaltar, no caso brasileiro, que a situação econômica do país não permite mais os subsídios à agricultura nos moldes praticados nos anos 70, o que pressionava o déficit fiscal e, em última instância, o processo inflacionário. Por outro lado, devido às características inerentes ao mercado de crédito, a simples saída do governo desse mercado não representa uma solução, mas uma mudança de face do problema (a necessidade de se gerar recursos para a atividade agrícola).

Propondo um novo padrão de atuação do governo, Stiglitz (1993) estabelece seis objetivos que devem ser a base de atuação do governo: proteção aos agentes econômicos, proteção das instituições financeiras, estímulo à competição no mercado, alocação direta de recursos, estabilidade macroeconômica e crescimento da economia. De forma mais direta, o governo deveria atuar na:

1. Criação de instituições financeiras;

2. Regulação das instituições financeiras;

3. Intervenção nas instituições via estrutura legal adequada;

4. Intervenção direta no mercado de capitais para aumentar a liquidez do mercado;

5. Execução de políticas regulatórias.

\subsubsection{As equalizações como um instrumento de transição}

O mecanismo de equalizações de juros é um instrumento utilizado pelo governo para alavancar recursos privados para o financiamento da atividade rural. Nos últimos anos esse instrumento tem sido utilizado em políticas como a de preços mínimos, PRONAF e também a política de crédito rural. 
As equalizações consistem na subvenção econômica aos preços agrícolas, ou mesmo de taxa de juros. Gasques et al. (2000) afirmam que estimativas elaboradas pela Secretaria do Tesouro Nacional, em 1996, mostraram que para cada real aplicado pelo governo no sistema de equalizações, foram mobilizados cerca de nove reais de recursos privados para aplicação no crédito rural.

Segundo dados do Banco Central foi concedido, pelo Sistema Nacional de Crédito Rural, algo em torno de sete bilhões de reais. Conforme os dados de Gasques et al. (2000), portanto, o sistema de equalizações com o governo gastando um bilhão de reais, possibilitaria a geração de mais recursos (nove bilhões de reais) que todo o Sistema Nacional de Crédito Rural.

Torna-se evidente que a prática de equalizações é importante, e eficiente, para a obtenção de recursos a serem destinados à agricultura, além do fato de não comprometer o equilíbrio fiscal almejado pelo governo e, indiscutivelmente, necessário para a manutenção da estabilidade monetária alcançada em meados de 1994. A agricultura brasileira, em uma fase de transição, entre um sistema totalmente mantido pelo Estado para um sistema basicamente de mercado, não pode prescindir de um instrumento de geração de recursos com o potencial demonstrado pelo sistema de equalizações.

\subsubsection{O papel das cooperativas na geração e difusão do crédito}

Segundo o modelo de Driscoll (1991), apresentado na seção 3.3.3, o aumento da oferta de crédito ocorre naturalmente quando se tem um sistema de classificação e seleção de risco dos empréstimos demandados.

Um novo sistema de crédito, mais atuante e eficiente, deve ter como características a descentralização e horizontalização. A atuação de cooperativas capacitadas a operar com crédito rural parece ser um elo de ligação entre as exigências de um novo sistema de crédito rural e o resultado teórico do modelo de Driscoll (1991). Em um sistema de crédito descentralizado as cooperativas representam um mecanismo para o aumento da capilaridade do sistema, além de possuir maiores facilidades para 
análise individual dos empréstimos concedidos aos produtores locais, de forma que o risco de um default se torna muito menor que o verificado no modelo atual.

Bittencourt \& Michelon (1999) realizaram um importante trabalho que ilustra o potencial de captação e distribuição de crédito das cooperativas. O sistema Cresol, por eles estudado, representa uma integração solidária entre cooperativas de créditos autorizadas pelo Banco Central e conveniadas com o Banco do Brasil. A formação e administração das cooperativas são coordenadas por agricultores familiares que se articulam com organizações populares, e cada cooperativa tem sua agência e postos de atendimento. Cada cooperativa do sistema Cresol tem autonomia, porém todas são integradas através da Cooperativa Central de Recursos (Cresol-Baser).

O sistema Cresol tinha 920 sócios em junho de 1996 e, em julho de 1999, havia 9470 associados distribuídos entre os estados do Rio Grande do Sul, Paraná e Santa Catarina. No biênio 1996/1997 a Cooperativa Central de Recursos realizou convênios com o Banco do Brasil para repasse e compensação de recursos do PRONAF destinados ao custeio da produção, e com o BNDES para o repasse dos recursos do PRONAF para investimentos. Os empréstimos recebem como garantia o aval solidário entre os associados do sistema Cresol, além das garantias também concedidas pelas cooperativas locais de crédito (Bittencourt \& Michelon, 1999).

A limitação do sistema de cooperativas, nos moldes do sistema Cresol, está no pouco volume de recursos destinados ao PRONAF. Incentivos de parcerias entre as cooperativas e instituições financeiras privadas poderiam possibilitar maior volume de recursos aos produtores, uma vez que um dos maiores entraves à maior participação dos bancos privados no crédito rural é a falta de credibilidade dos tomadores. Através das cooperativas seria possível a criação de um sistema de informações sobre a situação financeira dos associados, o que permitiria a redução da assimetria de informação entre os bancos privados e os tomadores de empréstimos. Outro ponto a se destacar é o fato de as cooperativas poderem aturar como intermediárias nos empréstimos, o que reduz os custos bancários de transação nas operações de crédito rural. 


\subsection{As novas fontes de financiamento}

Todos os estudos recentes sobre crédito rural no Brasil apontam para a exaustão do sistema atual baseado, em grande parte, nos recursos advindos do governo federal. Apesar da necessidade de se encontrar um novo sistema de financiamento que seja sustentável, no longo prazo, em sua capacidade de gerar recursos para o setor rural e que contemple todas as categorias de produtores agrícolas, ainda não se definiu um padrão de financiamento que deverá ser seguido nos próximos anos.

Até o momento os rumos tomados pela agricultura, na obtenção de recursos financeiros, apontam para um modelo essencialmente de mercado, uma vez que o Estado definiu como prioridade a estabilidade monetária, muito dependente do equilíbrio fiscal do governo, de forma que não há mais condições de se voltar ao cenário dos anos 70 em que a agricultura era subsidiada por recursos públicos. A priori, o equilíbrio fiscal não necessariamente impediria apoio ao crédito agrícola, entretanto, as fontes de recursos públicos não podem ser geradoras de pressão inflacionária como a expansão monetária, por exemplo.

Os recursos privados destinados ao financiamento rural, como a CPR e o sistema de troca de produtos por insumos, têm crescido consideravelmente; porém, deve-se salientar que enfrentam obstáculos como alto custo das operações e, devido à inexistência de uma legislação específica e adequada, insegurança quanto ao cumprimento de contratos entre outros. Não resta dúvidas, entretanto, que a maior participação do setor privado vai depender de uma reforma ampla do sistema financeiro que privilegie a criação de instrumentos de minimização de risco, desburocratização do crédito rural e maior participação dos bancos privados.

O Plano Real, enquanto um plano de estabilização da economia, foi muito bem sucedido. Porém, alguns dos fundamentos do plano, como as âncoras monetária e cambial, somados aos indexadores utilizados pelo mercado elevaram sobremaneira a dívida dos produtores rurais, o que gerou uma crise de pagamento dos recursos emprestados (tanto que foram necessárias renegociações, a última em outubro de 2001) e comprometeu a saúde financeira do sistema bancário. Sem um cenário macroeconômico favorável, ou seja, com taxas de juros mais compatíveis com as verificadas no cenário 
internacional, não será possível imaginar um modelo de financiamento da agricultura sustentável no longo prazo. Altas taxas de juros não só inibem investimentos diretos na economia como também aumentam os custos dos empréstimos, reduzem a capacidade de pagamento dos agricultores o que leva o setor privado a destinar menos recursos para a agricultura, aumenta o risco de seleção adversa na demanda de crédito, uma vez que apenas os tomadores de maior risco desejarão se defrontar com taxas de juros tão elevadas.

A literatura sobre mercado de crédito mostra que esse mercado tem como uma de suas características principais a assimetria de informação, ou seja, os tomadores de empréstimos têm maior conhecimento sobre a possibilidade de um default que os emprestadores. A presença de assimetria de informação, a falta de uma estrutura legal apropriada e a ausência de um sistema de informações, elevam os custos de transação do empréstimo. Eliminar essas falhas de mercado, ou pelo menos reduzir ao máximo seus efeitos, é o primeiro passo, para o governo, na elaboração de um novo modelo de financiamento da atividade rural.

No que se refere à assimetria, é essencial a descentralização de um novo sistema de crédito, sendo que a decisão quanto à concessão ou não do empréstimo deve ser decidida regionalmente. Muito provavelmente, as agências bancárias locais têm condições de, a um custo muito baixo, levantar informações sobre as condições financeiras dos produtores demandantes de crédito potenciais.

A priori, o Banco do Brasil pode ter uma função importante na construção desse modelo, pois é um dos poucos bancos que possuem agências espalhadas por todas as regiões do país, chegando a alcançar os municípios mais distantes. Através de um sistema de crédito descentralizado, o Banco do Brasil pode ser um instrumento relevante para aumentar a capilaridade do sistema (e reduzir a assimetria de informação, pois uma agência local tem condições de avaliar melhor a capacidade de pagamento do produtor da região que demanda crédito). Ou seja, atuando como se fosse um banco privado, o Banco do Brasil poderia investir em uma estrutura de apoio ao crédito rural e emprestar recursos aos produtores mais afastados dos grandes centros urbanos e, por conseguinte, com maiores dificuldades para obter os benefícios dos mercados financeiros. Outra 
vantagem de uma atuação desse tipo do Banco do Brasil seria a independência do sistema de atuações das cooperativas que, por enquanto, não conseguiram uma atuação eficiente no que se refere ao crédito rural. Sobre os custos bancários de transação, muito altos no caso brasileiro, os estudos citados neste trabalho mostram que a necessidade das agências trabalharem com poucos contratos, porém, de valores mais elevados, além de uma estrutura capaz de alocar funcionários para outras atividades nos períodos de demanda estacionária por crédito.

Além do desenvolvimento do mercado de CPR e outros instrumentos financeiros, Gasques \& Villa Verde (1999) sugerem outras três novas fontes de financiamento para a agricultura: Entidades Fechadas de Previdência Privada (EFPP), Fundo de Aposentadoria Programada Individual (FAPI) e os Fundos de Investimento em Empresas Emergentes (FIEE).

As Entidades Fechadas de Previdência Privada (EFPP), conforme Gasques \& Villa Verde (1999), são conhecidas como fundos de pensão e parte desses recursos devem ser aplicados da seguinte forma: $3 \%$, isolada ou cumulativamente, em cédula de crédito rural, notas promissórias rurais, cédulas de produto rural, certificados de mercadorias e outros títulos e contratos vinculados a produtos agrícolas, pecuários e agroindustriais.

O Fundo de Aposentadoria Programada Individual (FAPI), assim como os Fundos de Pensão, permitem a composição da carteira de aplicações de recursos em operações realizadas em mercados de derivativos sempre que as operações atenderem às condições de pregão competitivo em mercados administrados pelas bolsas de valores, e de mercadorias e futuros Gasques \& Villa Verde (1999).

Em 1994 a Comissão de Valores Mobiliários (CVM) regulamentou os Fundos de Investimento em Empresas Emergentes (FIEE), que passariam a ser mecanismos alternativos de crédito bancário para pequenas e médias empresas brasileiras.

A experiência brasileira com o Sistema Nacional de Crédito Rural (SNCR) mostra que é impossível criar um sistema eficiente de recursos financeiros e que, ao mesmo tempo, atenda às necessidades dos mais variados tipos de produtores, seja em relação à categoria de produtos ou de renda. Devido ao acesso restrito dos pequenos 
produtores ao mercado financeiro, e à falta de uma cultura associativista no Brasil, ainda é importante que o governo federal angarie recursos para a agricultura de menor escala, também chamada de familiar. Nesse sentido o desenvolvimento dos sistemas de microcrédito torna-se bastante relevante, além da continuidade de programas como o PRONAF (Programa Nacional da Agricultura Familiar).

Quanto aos grandes produtores, os maiores demandantes de crédito, é necessário incentivar o acesso ao mercado financeiro para que eles consigam não só recursos do setor privado nacional, como também recursos de fontes externas. Esse caminho passa por uma ampla reforma do sistema financeiro, que o torne mais acessível e que o custo das operações seja bem mais baixo que os atuais; por um desenvolvimento das atividades das seguradoras e criação de uma estrutura legal que garanta a eficiência do sistema.

Ainda sobre as reformas do sistema financeiro para torna-lo mais eficiente como instrumento de captação de recursos financeiros, Gasques et al. (2000) sugerem o fortalecimento do mecanismo de títulos para operações de contratos futuros da agricultura através da aquisição de títulos via recursos externos, o que incluiria no âmbito das reformas a maior utilização, por parte do setor agropecuário, de mecanismos como títulos e opções.

\subsubsection{Sugestões do banco interamericano de desenvolvimento (BID) para estratégias de financiamento rural}

O Banco Interamericano de Desenvolvimento (BID) em um relatório de dezembro de 1999, depois de um longo estudo sobre crédito rural na América Latina, elaborou uma série de sugestões para a formulação de estratégias de financiamento rural para a região. Algumas das sugestões contidas nesse estudo se aplicam favoravelmente ao caso brasileiro.

Em princípio, como já destacado nos últimos vinte anos pela teoria do mercado de crédito, as estratégias de financiamento rural devem se ater em três pontos cruciais: risco dos empréstimos, informação imperfeita e altos custos de transação. Especificamente no mercado de crédito, na América Latina, o BID destacou cinco 
problemas a serem resolvidos durante a implementação de um novo modelo de crédito rural:

1) Acesso limitado ao crédito formal de curto prazo;

2) Segmentação de mercado e falta de competição;

3) Disponibilidade limitada de crédito de médio-longo prazos;

4) Escassez de operacionalidade e sustentabilidade de intermediários financeiros;

5) Serviços financeiros limitados.

As primeiras recomendações do BID para a criação de um sistema sustentável que permita o desenvolvimento de estratégias de financiamento rural são:

1) Remoção do viés de políticas econômicas setoriais que reduzem a lucratividade e a competitividade das atividades econômicas rurais;

2) Remoção do viés de estruturas legais e regulatórias que aumentam os riscos e os custos de intermediação financeira nas áreas rurais;

3) Melhorar a capacidade dos serviços de financiamento rural, como o aumento da capilaridade do sistema;

4) Criação de novos serviços e produtos rurais.

Durante a década de setenta e alguns anos da década de oitenta o sistema de crédito rural no Brasil criou condições estruturais e econômicas que culminaram no subsídio do crédito agrícola. O resultado final foi o a redução dos incentivos à formação de poupança e o beneficiamento de tomadores de empréstimo com maior renda.

A viabilidade de um novo modelo de crédito rural depende, em primeira instância, da criação de um ambiente legal e regulatório capaz de permitir que os fundos de garantia dos empréstimos sejam alocados para a agricultura via bancos comerciais, e de forma que estes possam atuar com estratégias de empréstimo capazes de reduzir os riscos de default e que atinjam também os produtores de pequeno e médio porte (BID, op. cit.). Em seguida, deve-se seguir na linha de reformas setoriais e regulatórias, como a criação de instituições financeiras capazes de atender aos clientes rurais.

$\mathrm{O}$ relatório do BID sugere ainda outras cinco medidas para o setor rural desenvolver sua capacidade financeira: 
1) Organizações Não Governamentais (ONG’s) como intermediários financeiros legais;

2) Criar incentivos para os bancos comerciais assistirem pequenos e médios agricultores;

3) Estabelecer uma ligação entre intermediários formais e informais;

4) Reestruturar e reformar as instituições de empréstimos formais;

5) Criação de novas instituições.

O fortalecimento institucional dos intermediários financeiros é o fator determinante para implementação das sugestões apresentadas pelo BID. Não só a experiência brasileira, mas da América Latina em geral, apontam para um novo modelo, mais voltado para o mercado, e mais sustentado em recursos privados. Faz parte do processo de fortalecimento das instituições financeiras o preparo da infra-estrutura necessária, dar um enfoque eminentemente comercial às operações de empréstimo e serviços de fornecimento de tecnologia, pois a inovação tecnológica é decisiva na redução de custos de transação.

Uma vez mais, agora sob o enfoque do relatório do BID, destacar a importância do Banco do Brasil no processo de modernização do crédito rural do Brasil. A grande vantagem que este banco apresenta é ter agências espalhadas por todas as regiões do país, atingindo o nosso vasto interior. Desde que se invista em tecnologia e preparo da infra-estrutura (para reduzir custos de transação), e se mantenha a mentalidade comercial das operações, a atuação do Banco do Brasil pode ser o primeiro passo para o desenvolvimento de um novo sistema de crédito rural, enquanto não são implementadas reformas legais que tornem o mercado de crédito rural atrativo para os demais bancos comerciais do país. Outra alternativa seria o estabelecimento de parcerias entre as agências do Banco do Brasil com as cooperativas e ONG's locais. Nesse caso, o banco seria apenas um instrumento de captação dos recursos financeiros, e as cooperativas (ou ONG's) ficariam responsáveis pela alocação dos empréstimos entre os produtores da região, o que levaria a uma redução da assimetria de informação do sistema.

Finalmente, deve-se ressaltar, que buscar um único sistema capaz de atender grandes, médios e pequenos agricultores é um equívoco que a história recente do crédito 
rural no Brasil comprovou. Os grandes produtores conseguem ter mais acesso ao mercado financeiro e captar os recursos privados internos e externos, ainda que a juros elevados. Para essa categoria é preciso reformular o sistema financeiro de forma que as operações se tornem mais ágeis e baratas, além de haver a possibilidade de se contar com instrumentos financeiros que minimizem as variações de preços. Quanto aos pequenos e médios produtores deve-se investir em um sistema com infra-estrutura para atendê-los, nas mais diversas regiões do país, e com mentalidade estritamente comercial. As fontes de recursos, para os pequenos e médios produtores, devem ser provenientes não só do governo (a exemplo do PRONAF) como, também, de bancos comerciais que vejam nesse mercado (após as já mencionadas reformas legais e estruturais) um mercado atrativo para empréstimos e investimentos. 


\section{CONCLUSÕES}

O Sistema Nacional de Crédito Rural, iniciado em 1965 através da lei 4.289, entrou em colapso a partir dos anos 80. Os desembolsos do Tesouro Nacional, juntamente com os Recursos Obrigatórios representavam, em 1985, cerca de $96 \%$ do crédito rural e, em 1999, essa participação não chegava a 0,02\% do volume de recursos destinados à agricultura. A necessidade de controle dos gastos públicos, bem como a incapacidade do governo em desenhar um modelo alternativo contribuíram para o esgotamento do sistema tradicional de crédito para a agricultura.

$\mathrm{Na}$ década de 80, época em que a economia brasileira apresentou estagnação do crescimento do produto interno e elevadas taxas de inflação, ocorreu uma redução da participação do setor financeiro na atividade de financiamento da produção, e passou a financiar o déficit do setor público através da captação de recursos do imposto inflacionário sobre os depósitos à vista.

Os bancos privados, em função da diferença entre o tempo decorrido da captação de recursos via depósitos à vista e o repasse desses recursos aos credores finais e a possibilidade de aplica-los no over-night, elevou sobremaneira os lucros do setor bancário que, devido à baixa concorrência e elevados custos operacionais, estabeleceu spreads bastante altos para as operações de empréstimos, o que tornou muito desfavorável à tomada de crédito na economia.

No âmbito macroeconômico as taxas de juros praticadas no Brasil, em valores reais, são muito altas, situação essa que se iniciou nos anos 80 e permaneceu nos anos 90. A justificativa para o aumento de juros, na década de 80 , foi a contenção monetária para o controle da inflação, e pela diminuição da poupança mundial que se reduziu devido ao déficit fiscal dos Estados Unidos e a redução da poupança privada de outros países. Já nos anos 90, com a implementação do Plano Real, o controle inflacionário 
ficou extremamente dependente das âncoras monetária e cambial, ou seja, de elevadas taxas de juros no mercado financeiro e valorização da taxa de câmbio em relação ao dólar.

Com um cenário macroeconômico tão desfavorável, a renda agrícola brasileira teve um desempenho muito fraco na década de 90. Além disso, em função do descasamento entre a correção dos preços mínimos aos produtores e a correção da dívida dos mesmos (correção de 41,28\% dos preços mínimos pelo IPC, e correção da dívida em torno de 84,23\% pelo mesmo indicador de preços), observou-se a partir de 1994 um elevado crescimento da dívida dos produtores rurais. Outro entrave macroeconômico são as altas taxas de juros, incompatíveis com as praticadas nos mercados financeiros internacionais, que acabam por inibir os investimentos diretos na economia, aumentam os custos dos empréstimos, reduzem a capacidade de pagamento dos agricultores e reduz o volume de recursos destinados do setor privado para a agricultura. Portanto tornou-se mais difícil para a agricultura brasileira obter financiamento formal.

Dadas as características peculiares do mercado de crédito, como assimetria de informação e externalidades, a variável taxa de juros não explica satisfatoriamente o comportamento do mercado de crédito, pois se elevada pode atrair tomadores de alto risco de default para o mercado e diminuir o retorno esperado dos fornecedores de empréstimo. A informação torna-se, no mercado de crédito, uma falha de mercado que restringe o volume de recursos privados e faz com que o equilíbrio de mercado ocorra com excesso de demanda por empréstimo, uma vez que para evitar o problema de seleção adversa os ofertantes de crédito reduzem a taxa de juros de empréstimo a um nível inferior ao que seria dado pela igualdade entre oferta e demanda por empréstimos.

As evidências teóricas mostram, portanto, que o mercado de crédito funcionando livremente não é capaz de gerar um volume de recursos igual ao socialmente desejável. Isso significa que a ausência total do governo, como vem acontecendo no Brasil, não representa a solução ideal para o financiamento da agricultura no Brasil.

Desde a criação do Sistema Nacional de Crédito Rural (SNCR) em 1965, até o esgotamento do sistema no final dos anos 90, o governo federal foi o principal 
fomentador de recursos para o crédito agrícola. No entanto, dada as várias ineficiências do sistema tradicional (de equidade e eficiência) e a necessidade do governo realizar o ajuste fiscal a fim de garantir a estabilidade monetária, os recursos federais destinados ao financiamento rural tornaram-se cada vez mais escassos.

A realidade da economia brasileira, atualmente, torna totalmente descartável e inconcebível um simples retorno ao passado. Por outro lado, consiste em um erro grave, do ponto de vista teórico, e com graves consequiências para a agricultura, do ponto de vista prático, uma ausência total do governo mercado de crédito. Primeiramente, enquanto se caminha para um sistema mais voltado para o mercado, é necessário um período de transição e, nesse contexto, as equalizações (subvenção econômica de preços agrícolas, ou de taxas de juros) são um instrumental importante, haja vista que dados recentes mostram que para cada real aplicado pelo governo no sistema de equalizações foram obtidos nove reais de recursos privados aplicados em crédito rural.

Outros instrumentos importantes em um período de transição para um sistema de crédito essencialmente voltado para os recursos privados são as fontes não inflacionárias como as Entidades Fechadas de Previdência Privada (EFPP), Fundo de Aposentadoria Programada Individual (FAPI) e os Fundos de Investimento em Empresas Emergentes (FIEE). Além disso, o sistema de cooperativas também tem se mostrado muito eficiente na provisão de recursos para os produtores de pequeno porte, e distribuição dos recursos advindos do PRONAF.

A nova forma de atuação do governo federal no mercado de crédito rural diz respeito à regulação desse mercado, via proteção aos agentes econômicos, proteção das instituições financeiras, estímulo à competição no mercado, estabilidade macroeconômica, alocação direta de recursos (principalmente para a agricultura familiar) entre outros. O Banco do Brasil, dada a sua enorme estrutura e abrangência em várias regiões do país, é capaz de aumentar a capilaridade do sistema (e reduzir a assimetria de informação, pois uma agência local tem condições de avaliar melhor a capacidade de pagamento do produtor da região que demanda crédito), e prover recursos para os produtores com maiores dificuldades de acesso ao mercado financeiro. 
O instrumento de captação de recursos privados que, certamente, tem mais potencial para se desenvolver é a CPR. Entretanto, deve-se ressaltar que o elevado custo de aval, as taxas de juros da economia, e a falta de tomadores de risco no mercado financeiro brasileiro são fatores limitadores ao mecanismo de venda de CPR's.

A história do crédito rural brasileiro demonstra que não é possível criar um sistema que atenda, eficientemente, todas as classes de produtores. Os grandes produtores têm a vantagem de obter recursos privados internos e externos no mercado financeiros e, para essa categoria, a atuação do governo deve se basear na reformulação do sistema financeiro de forma que as operações se tornem mais ágeis, baratas e sejam criados instrumentos financeiros que minimizem os efeitos de variações nos preços agrícolas. Quanto aos pequenos produtores, por sua vez, deve-se incentivar os agentes privados (via estrutura legal adequada) a atuarem nesse mercado, bem como o governo garantir os recursos já destinados a essa classe, como o PRONAF, por exemplo, de forma que a escassez de crédito rural não seja um entrave para o desenvolvimento da agricultura brasileira futuramente. 


\section{REFERÊNCIAS BIBLIOGRÁFICAS}

ABREU, M. P.; LOYO, E. A estrutura do comércio agrícola mundial. In: FAGUNDES, M. H. (Org). Políticas agrícolas e o comércio mundial. Brasília: IPEA, 1994.

AKERLOF, G. The market for "lemons": quality, uncertainty and the market mechanism. Quarterly Journal of Economics, v.84, n.3, p.488-500, 1970.

ALMEIDA, A. de. Mercados informais como fonte alternativa de liquidez para os agricultores. Piracicaba, 1994. 204p. Dissertação (M.S) - Escola Superior de Agricultura "Luiz de Queiroz", Universidade de São Paulo.

ARAÚJO, P.F. C. de; MEYER, R. L. Agricultural credit policy in Brazil: objectives and results. American Journal of Agricultural Economics, v.59, n.5, p.957-961, Dec. 1977.

ARAÚJO, P.F. C. de. Agricultura brasileira sem subsídio. Revista de Economia e Sociologia Rural, v.21, n.3, p. 296-303, 1983.

ARAÚJO, P.F. C. de. Crédito rural e endividamento em período recente. Preços Agrícolas, v.14, n.161, p. 3-6, mar. 2000.

ARAÚJO, P.F. C. de; BARROS, A M.; ALMEIDA. A turbulência e indefinição no financiamento à agricultura. In: Agricultura, economia e sociedade: ensaios em homenagem ao prof. Fernando Estácio. Lisboa: IFADAP, 2001. p.83-97.

ARAÚJO, U. M. Assimetria de informação no crédito rural: aspectos teóricos e um modelo para classificação do risco dos créditos concedidos a cooperativas agropecuárias. Piracicaba, 1996. 81p. Tese (Doutorado) - Escola Superior de Agricultura “Luiz de Queiroz”, Universidade de São Paulo.

BANCO MUNDIAL. A importância das finanças. Relatório sobre o desenvolvimento mundial. Rio de Janeiro: Fundação Getúlio Vargas, 1989. p.27-43.

BANCO MUNDIAL. Rural finance strategy. Washington, 1999. 54p. 
BARROS, G. S. C.; ARAÚJO, P.F. C. de. Estimativas de custos bancários de transação do crédito rural no Brasil. Piracicaba: CEPEA/FEALQ, 1991. 41p. (Relatório de Resultados, 7)

BARROS, J. R.M.de. Política e desenvolvimento agrícola no Brasil. In: VEIGA, A. (Ed.) Ensaios sobre política agrícola. São Paulo: Secretaria da Agricultura, 1979. p.9-36.

BITTENCOURT, G. A.; MICHELON, A. CRESOL-BASER: sistema de cooperativas de crédito rural com interação solidária, 1999. 61p. (Projeto CUT/CONTAG de Pesquisa e Formação Sindical, Série Experiências 09)

BRAGA, M. B. A. Economia da informação e os mercados de crédito: algumas contribuições teóricas à moderna teoria de intermediação financeira. São Paulo, 1998. 141p. Tese (Doutorado) - Faculdade de Economia, Administração e Contabilidade, Universidade de São Paulo.

CARVALHO, A G. Ascensão e declínio do mercado de capitais no Brasil: a experiência dos anos 90. Economia Aplicada, v.4, n.3, p. 595-632, jul./set. 2000.

DIAS, G. L. S.; SOARES, P. T. L. Crédito rural: uma nota adicional. Estudos Econômicos, v.9, n.2, p.47-55, 1979.

FRY, M. J. Money, interest, and banking in economic development. Baltimore: The John Hopkins University Press, 1982. chap. 1 e 2, p. 3-63.

GASQUES, J. G.; VERDE, C. M. V. Novas fontes de recursos, propostas e experiências de financiamento rural. Revista de Economia e Sociologia Rural, v.34, n.3/4, p.39-80, 1996.

GASQUES, J. G.; VERDE, C. M. V. Financiamento da agricultura: outras alternativas. /Apresentado no Workshop Instrumentos Públicos e Privados de Financiamento e de Gerenciamento de Risco, Piracicaba, 1999/

GASQUES, J. G.; CONCEIÇÃO.J.C. P. R. Fatores que afetam a oferta de recursos do crédito rural. Preços Agrícolas, v.14, n. 161, p. 7-8, mar. 2000.

GASQUES, J. G.; CONCEIÇÃO.J.C. P. R.; RODRIGUES, R. I. Financiamento da agricultura: experiências e propostas. Brasília: IPEA, 2000. 67p. (Projeto BRA 97/013)

GASQUES, J. G.; CONCEIÇÃO, J. C. P. R.; RODRIGUES, R. I. Mudanças no crédito. Revista de Agronegócios, v.21, n.1, p.48-49, jan. 2001. 
GONZALEZ, B. C. R. Os ambientes contratual e operacional da cédula de produto rural (CPR) e interações com os mercados futuros e de opções. Piracicaba, 1999. 169p. Tese (Doutorado) - Escola Superior de Agricultura “Luiz de Queiroz", Universidade de São Paulo.

GONZALEZ, B. C. R. Novas formas de financiamento da produção, Base do Agronegócio. In: MONTOYA, M. A; PARRÉ, J. L.(Orgs) O agronegócio brasileiro no final do século XX: estrutura produtiva, arquitetura organizacional e tendências. Passo Fundo: UPF Editora, 2000. p.91-108.

GONZALEZ, B. C. R.; MARQUES, P. V. Características, vantagens e riscos da CPR com liquidação financeira. Preços Agrícolas, v.14, n.161, p.15-17, mar. 2000.

GUEDES FILHO, E. M. Financiamento na agricultura brasileira. /Apresentado no Workshop Instrumentos Públicos e Privados de Financiamento e de Gerenciamento de Risco, Piracicaba, 1999/

GUIDETTI, J. C. S.; ARAÚJO, P.F.C. de. Custos bancários de transação no crédito rural: revisão de literatura e aspectos metodológicos. Piracicaba: ESALQ/USP, 1994. 23p. (Relatório Parcial do Projeto "Estimativas de custos bancários de transação do crédito rural: estudo de uma amostra no Estado de São Paulo”)

GUIDETTI, J. C. S.; ARAÚJO, P.F.C. de. Custos bancários de transação no crédito rural em agências de banco oficial. Piracicaba: ESALQ/USP, 1994. 21p. (Relatório Final do Projeto "Estimativas de custos bancários de transação do crédito rural: estudo de uma amostra no Estado de São Paulo”)

GUIDETTI, J. S. Relações entre custo de transação de um banco privado e crédito rural. Piracicaba, 1998. 85p. Dissertação (M.S.) - Escola Superior de Agricultura "Luiz de Queiroz", Universidade de São Paulo.

HELFAND, S. M. Distribuição de crédito agrícola subsidiado no Brasil: grupos de interesse têm importância? Riverside: Universidade da Califórnia, 2000. 30p.

HOFF, K.; STIGLITZ, J. E. A theory of imperfect competition in rural credit markets in developing countries. Washington: IPR, 1993. 39p. (Working Paper Series)

HOFFMANN, R.; KAGEYAMA, A. Crédito rural no Brasil: concentração regional e por cultura. Revista de Economia e Sociologia Rural, v.25, n.1, p.31-50, jan./mar. 1987.

JAFFEE, D. M.; RUSSELL, T. Imperfect information, uncertainty, and credit rationing. Quarterly Journal of Economics, v. 90, n.2, p. 651-666, 1976. 
JAYO, M.; SAES, M.S.M. Política agrícola: os futuros têm futuro? Informações Fipe, n.187, p.21-23, abril 1996.

LIMA, R. A. S. Financiamento agrícola: estruturando uma solução. /Apresentado no Workshop Instrumentos Públicos e Privados de Financiamento e de Gerenciamento de Risco, Piracicaba, 1999/

MATA, M. Crédito rural: caracterização do sistema e estimativas dos subsídios implícitos. Revista Brasileira de Economia, v.36, n.3, p.215-245, jul/set. 1982.

MELO, F.B.H. de. Agricultura brasileira nos anos 90: o real e o futuro. Economia Aplicada, v.2, n.1, p. 163-182, 1998.

MELO, F.B.H. de A década dos anos 90 e o desempenho agropecuário brasileiro. Informações Fipe, n.243, p.20-23, jan. 2001.

MENDONÇA, H. F. Metas de inflação: uma análise preliminar para o caso brasileiro. Economia Aplicada, v.5, n.1, p.129-157, jan./mar. 2001.

MEYER, R. L.; ADAMS, D.; RASK, N.; ARAÚJO, P.F. C. de. Mercados de crédito no brasil e os pequenos agricultores no Brasil. In: ARAÚJO, P.F. C. de; SCHUH, E. (Ed.) Desenvolvimento da agricultura: análise de política econômica. São Paulo: Livraria Pioneira Editora, 1977. cap. 3, p. 151-204.

MEYER, R.; NAGARAJAN, G. Innovation in financial markets: implications for rural development. /Apresentado à 23. Conferência da Associação Internacional de Economistas Agrícolas, Sacramento - Califórnia, 1997/

OLIVEIRA, J. C.; MONTEZANO, R. M. S. Os limites das fontes de financiamento à agricultura no Brasil. Estudos Econômicos, v.12, n.2, p.139-159, ago.1982.

OLIVEIRA, J. J. O impacto da crise fiscal brasileira dos anos 80 no crédito rural: mecanismos e instrumentos alternativos de financiamento agrícola. São Paulo, 1995. 149p. Dissertação (M.S) - Fundação Getúlio Vargas.

PESSOA, A.S.M. Custos bancários de transação do crédito rural no Brasil. Piracicaba, 1996. 229p. Dissertação (M.S) - Escola Superior de Agricultura "Luiz de Queiroz", Universidade de São Paulo.

PIMENTEL, F. CPR: de onde partimos e para onde vamos? Preços Agrícolas, v.14, n.161, p. 9-11, mar. 2000.

SACHS, J.; LARRAIN, F.B. Macroeconomia. São Paulo: Makron Books, 1995. 904p. 
SANTIAGO, M. M. D.; SILVA, V. A política de crédito rural brasileira e o endividamento do setor agrícola: antecedentes e desdobramentos recentes. Agricultura em São Paulo, v.46, n.2, p.47-69, 1999.

SANTIAGO, M. M. D. Uma análise econométrica da dívida agrícola brasileira: o caso da poupança rural. Agricultura em São Paulo, v.47, n. 2, p.21-40, 2000.

SAYAD, J. Crédito rural no Brasil. Brasília: Ministério da Agricultura, 1978. 93p.

SAYAD, J. Crédito rural e taxas de juros reais positivas. In: ENCONTRO NACIONAL DE ECONOMIA, 9., Olinda, 1981. Anais. Brasília: ANPEC, 1981. p.439-462.

SAYAD, J. Estratégias de transição para reforma do crédito rural. In: CONGRESSO BRASILEIRO DE ECONOMIA E SOCIOLOGIA RURAL, 20., Curitiba, 1982. Anais. Brasília: SOBER, 1982. p.127-144.

SCHOUCHANA, F.; PEROBELLI, F. S. O financiamento da agricultura e o mercado futuro. Resenha BM\&F, n. 142, p.78-93, 2001.

SCHOUCHANA, F. CPR com liquidação financeira e abertura do mercado de opções para não residentes. Preços Agrícolas, v.14, n.161, p. 18, mar. 2000.

SERVILHA, V. O financiamento da agricultura brasileira. Campinas, 1994. 228p. Tese (Doutorado) - Instituto de Economia, Universidade Estadual de Campinas.

SHIROTA, R. Crédito rural no Brasil: subsídio, distribuição e fatores associados. Piracicaba, 1988. 229p. Dissertação (M.S) - Escola Superior de Agricultura "Luiz de Queiroz", Universidade de São Paulo.

STIGLITZ, J. E.; WEISS, A. Credit rationing in markets with imperfect information. American Economic Review, v.71, n.3, p.393-410, June 1981.

STIGLITZ, J. E. The role of the state in financial markets. /Apresentado à Conferência Anual do Banco Mundial sobre Desenvolvimento Econômico, Washington, 1993/

TENDLER, J. Agricultural credit in Brazil, agency for international development. Washington: Agency for International Development, 1969. 82p.

TOLEDO, J. E. C. Políticas econômicas e estabilização no plano real. Economia Aplicada, v.2, n.1, p.61-77, mar.1999.

YARON, J.; BENJAMÍN Jr. ; PIPREK, G. Financiamiento rural: problemas, diseño y prácticas óptimas. Washington: World Bank, 1999. 